Tiedemann, R., Mix, A.C., Richter, C., and Ruddiman, W.F. (Eds.)

Proceedings of the Ocean Drilling Program, Scientific Results Volume 202

\section{Pliocene Changes in tropical EASt PACIFIC UPPER OCEAN STRATIFICATION: RESPONSE TO TROPICAL GATEWAYS? ${ }^{1}$}

\author{
Silke Steph, 2,3 Ralf Tiedemann, ${ }^{4}$ Jeroen Groeneveld, ${ }^{2,5}$ \\ Arne Sturm, ${ }^{2,3}$ and Dirk Nürnberg ${ }^{2}$
}

\begin{abstract}
A combination of stable isotope records and $\mathrm{Mg} / \mathrm{Ca}$ temperature estimates of four different planktonic foraminiferal species from Ocean Drilling Program Site 1241 allows differentiation between temperature and salinity changes in the tropical east Pacific (TEP) upper water column during the Pliocene $(\sim 5.7-2.1 \mathrm{Ma})$. The deviation of $\delta^{18} \mathrm{O}$ records and $\mathrm{Mg} / \mathrm{Ca}$ temperature estimates from thermocline-dwelling planktonic foraminifers suggests that local changes in salinity exerted a much stronger control on Pliocene TEP upper ocean water mass signatures than previously assumed. The most pronounced Pliocene change in TEP upper ocean stratification was the shoaling of the thermocline from $\sim 4.8$ to $4.0 \mathrm{Ma}$ that was possibly triggered by changes in the configuration of low-latitude ocean gateways. During this time interval, mixed-layer temperatures and salinities remained relatively constant in contrast to a pronounced temperature $\left(\sim 6^{\circ} \mathrm{C}\right)$ and salinity decrease at the bottom of the photic zone. This change led to a new state in the thermal structure of the TEP, as the thermocline remained relatively shallow until $\sim 2.1 \mathrm{Ma}$.
\end{abstract}

${ }^{1}$ Steph, S., Tiedemann, R., Groeneveld, J., Sturm, A., and Nürnberg, D., 2006. Pliocene changes in tropical east Pacific upper ocean stratification: response to tropical gateways? In Tiedemann, R., Mix, A.C., Richter, C., and Ruddiman, W.F. (Eds.), Proc. ODP, Sci. Results, 202: College Station, TX (Ocean Drilling Program), 1-51. doi:10.2973/odp.proc.sr.202.211.2006 ${ }^{2}$ Leibniz-Institute of Marine Sciences, IFM-GEOMAR, Wischhofstrasse 1-3, 24148 Kiel, Germany.

${ }^{3}$ Present address: Alfred Wegener Institute for Polar and Marine Research, Columbusstrasse, 27568 Bremerhaven, Germany. Correspondence author: ssteph@awi-bremerhaven.de ${ }^{4}$ Alfred Wegener Institute for Polar and Marine Research,

Columbusstrasse, 27568 Bremerhaven, Germany.

${ }^{5}$ Present address: Department of Geosciences, University of Bremen, Leobener Strasse, 28359 Bremen, Germany.

Initial receipt: 19 November 2004 Acceptance: 14 January 2006

Web publication: 19 October 2006

Ms 202SR-211 


\section{INTRODUCTION}

The early to middle Pliocene includes the most recent period when Earth's climate was significantly warmer than present, as indicated by ocean temperature estimates from marine microfauna and by palynological data (e.g., Dowsett et al., 1992, 1994, 1996). This warm period was terminated by an irreversible global cooling trend after $\sim 3.2 \mathrm{Ma}$ that was associated with the intensification of Northern Hemisphere glaciation (NHG).

Two recent hypotheses link the major onset of NHG to modifications in ocean heat transport and thermohaline circulation that were attributed to the constriction of low-latitude ocean gateways. Several studies suggested that the progressive closure of the Central American Seaway (CAS) was the cause either for the onset (Berggren and Hollister, 1974) or for the delay (Berger and Wefer, 1996) or for setting preconditions for NHG (Haug and Tiedemann, 1998; Driscoll and Haug, 1998). Others identified narrowing of the Indonesian Gateway (IG) and associated changes in tropical Pacific oceanography as a mechanism that may have contributed to Pliocene cooling (e.g., Cane and Molnar, 2001). The ultimate causes for the late Pliocene-Pleistocene climate transition, however, are still under debate (e.g., Ravelo et al., 2004).

The closure history of the CAS (14-1.9 Ma) has been intensely investigated and is stratigraphically well constrained (e.g., Keigwin, 1982; Webb, 1985; Lundelius, 1987; Duque-Caro, 1990; Coates et al., 1992, 2004; Collins et al., 1996; Haug and Tiedemann, 1998). The Pliocene time interval from 4.6 to $4.2 \mathrm{Ma}$ has been shown to represent a critical period in the closure history, when the restriction of Pacific-Atlantic surface water exchange resulted in profound changes in ocean circulation and chemistry. Closure-induced variations mainly affected the Atlantic Ocean, as indicated by ocean model experiments (e.g., MaierReimer et al., 1990; Mikolajewicz and Crowley, 1997; Nisancioglu et al., 2003; Prange and Schulz, 2004) and paleoceanographic studies (e.g., Keigwin, 1982; Tiedemann and Franz, 1997; Haug and Tiedemann, 1998; Haug et al., 2001; Steph et al., in press). The main changes include strengthening of the Gulf Stream system, enhanced thermohaline overturn in the North Atlantic, development of the Caribbean Warm Pool, and an increase in Caribbean sea-surface salinity (SSS). The closure-induced impact on tropical Pacific oceanography yet remains ambiguous because of possible interactions resulting from the constriction of the IG.

The IG has narrowed gradually since 20 Ma due to the northward drift and collision of the Australia-New Guinea block with Indonesian terranes (e.g., Hamilton, 1979). In contrast to the CAS, the Pliocene history of the IG is stratigraphically not well constrained and is not characterized well enough to relate oceanographic changes in the tropical Pacific and Indian Ocean directly to gateway-induced thresholds. By reevaluating plate tectonic models, Cane and Molnar (2001) proposed that the Pliocene narrowing of the passage after 5.0-3.0 Ma may have strengthened the West Pacific Warm Pool (WPWP) and enhanced the tropical trans-Pacific sea-surface temperature (SST) gradient. These changes are corroborated by ocean general circulation models that examined closure-related oceanographic changes in the Pacific and Indian Oceans (e.g., Hirst and Godfrey, 1993; Godfrey, 1996). Development of the trans-Pacific temperature gradient is expected to have modified the thermal structure of the tropical Pacific from an El Niño-like state into 
S. STEPH ET AL.

more modern conditions of a La Niña-like state. This includes the shoaling of the east Pacific thermocline.

Indeed, low-latitude proxy records indicate that significant tropical climate reorganization occurred twice: once between 4.5 and 4.0 Ma, well before significant NHG, and once between 2.0 and $1.5 \mathrm{Ma}$, well after the onset of significant NHG (Ravelo et al., 2004). Evidence for early Pliocene changes in east Pacific surface water and atmospheric circulation toward more modern conditions comes from Farrell et al. (1995) and Hovan (1995). According to Farrell et al. (1995), carbonate and opal accumulation in the tropical east Pacific (TEP) decreased significantly and the maximum of opal accumulation shifted toward the east at $\sim 4.4$ Ma. Based on eolian grain size and flux studies, Hovan (1995) postulated a southward shift of the Intertropical Convergence Zone (ITCZ) between 5.0 and $4.0 \mathrm{Ma}$ consistent with observed changes in thermocline depth. Faunal assemblages and planktonic $\delta^{18} \mathrm{O}$ records from tropical Pacific Ocean Drilling Program (ODP) Sites 806 and 847 suggest that the development of the modern trans-Pacific thermocline slope crossed a critical threshold between 5.0 and 4.0 Ma (Chaisson and Ravelo, 2000). This change is characterized by shoaling of the thermocline in the TEP, which was also recorded in multispecies planktonic stable isotope records from TEP Site 851 as documented by Cannariato and Ravelo (1997). Recently, the comparison of planktonic $\mathrm{Mg} / \mathrm{Ca}$ SST records from the tropical east and west Pacific indicated that SST in the WPWP were similar or slightly higher than in the TEP during the Pliocene (Wara et al., 2005). The development of a more modernlike transequatorial SST gradient with higher temperatures in the WPWP and lower temperatures in the east Pacific was not observed to start before 2.0-1.5 Ma (Cannariato and Ravelo, 1997; Ravelo et al., 2004; Wara et al., 2005).

This study sheds new light on the thermal structure of the upper water column in the TEP (Site 1241) by establishing and combining stable isotope and $\mathrm{Mg} / \mathrm{Ca}$ records of shallow- and deep-dwelling planktonic foraminifers for the time interval from $\sim 5.7$ to $2.1 \mathrm{Ma}$. The comparison with planktonic $\delta^{18} \mathrm{O}$ records from TEP Site 851 (Cannariato and Ravelo, 1997) allows further assessment of regional variability in TEP upper ocean water mass signatures during the Pliocene. In addition, the position of Site 1241 close to Panama is appropriate to verify the influence of the Pliocene closure of the CAS on TEP surface hydrography.

\section{Regional Oceanography and Paleodrift of Site 1241}

TEP ODP Site 1241 had its origin near the equator at the Galapagos hotspot $\left(\sim 0.96^{\circ} \mathrm{S}, 91.82^{\circ} \mathrm{W}\right) \sim 11-13 \mathrm{~m}$.y. ago. During the past $11 \mathrm{~m} . \mathrm{y}$. , tectonic movement of the Cocos plate shifted the site location $\sim 950 \mathrm{~km}$ to the northeast toward its modern position at $\sim 5.84^{\circ} \mathrm{N}, 86.44^{\circ} \mathrm{W}$ (Mix, Tiedemann, Blum, et al., 2003) (Fig. F1). Hence, three ocean currents are considered to have influenced the upper $100 \mathrm{~m}$ of the water column at Site 1241: the South Equatorial Current (SEC), the North Equatorial Countercurrent (NECC) and the Equatorial Undercurrent (EUC) (Fig. F1). Today, the westward-flowing SEC (south of $3^{\circ} \mathrm{N}$ ) is driven by the southeast trade winds and is fed by relatively cool and salt-rich water masses from the South Pacific that are transported equatorward via the Peru-Chile Current. These water masses form the equatorial cold tongue, whereas low SST and a shallow thermocline are maintained by permanent equatorial upwelling, as the southeast trades cross the equator all year (Wyrtki, 1966; Strub et al., 1998). The NECC is located

F1. Map of the TEP, p. 34.

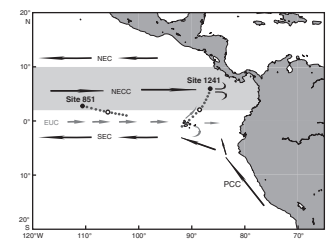


within the ITCZ region (between $3^{\circ}$ and $10^{\circ} \mathrm{N}$ ) and carries the return flow of relatively warm, low-salinity surface waters eastward out of the WPWP region (Wyrtki, 1981; Delcroix et al., 1987; Donguy and Meyers, 1996). Between $2^{\circ} \mathrm{N}$ and $2^{\circ} \mathrm{S}$, the EUC flows eastward along the equator in 30-300 m depth (Wyrtki, 1966; Philander, 1973; McPhaden, 1986). The EUC is a geostrophic current driven by the Coriolis force and by west-east pressure gradients. It rises with the thermocline as it flows across the Pacific, bringing relatively cool, high-salinity, and nutrientenriched water to the surface layer west of Galapagos Islands and extending into the Panama Bight (e.g., Wyrtki, 1981; Leetma, 1982; Bryden and Brady, 1985).

Considering the paleodrift of Site 1241 and assuming modern oceanographic conditions for the past 11 m.y., Site 1241 should reflect changes in upper ocean water mass signatures that are summarized in Figure F2. Figure F2 shows modern annual-average properties of the upper water column at paleolocations of Site 1241 for the last $11 \mathrm{~m} . \mathrm{y}$. (Conkright et al., 2002) based on plate tectonic backtracking (Mix, Tiedemann, Blum, et al., 2003). During the last 11 m.y., SST should have increased by $\sim 5^{\circ} \mathrm{C}$ and SSS should have decreased by as much as 1.5 as Site 1241 moved northward out of the cool and relatively salt rich SEC into warmer, low-salinity waters of the NECC (Fig. F2). Mixedlayer temperatures $\left(25-\mathrm{m}\right.$ water depth) reflect the same trend. The $22^{\circ} \mathrm{C}$ isotherm (assumed to represent mean thermocline temperatures; see Fig. F3) would have deepened from $\sim 5$ to $\sim 45 \mathrm{~m}$ (Fig. F2) if equatorial upwelling of cool subsurface waters, like today, connected the thermocline to the surface during the early history of Site 1241 . The major step in thermocline deepening should have occurred between 11 and 7 Ma ( 5-37 m), followed by a minor deepening from 37 to $45 \mathrm{~m}$ during the past $7 \mathrm{~m}$.y. Water temperature and salinity at $100-\mathrm{m}$ water depth (below the thermocline) would have remained relatively constant during the last 11 m.y. Nutrient concentrations (represented by phosphate concentrations in Fig. F2) at the sea surface would have decreased over the past 11 m.y. in response to the northward drift of Site 1241 out of the SEC/EUC region, where upwelling maintains relatively high nutrient concentrations near the surface. The opposite trend is observed for nutrient concentrations at 100-m water depth. At this depth level, water masses adjacent to the EUC have higher nutrient concentrations. Accordingly, the northward drift away from the EUC probably resulted in increasing nutrient concentrations. In summary, these changes in temperature, salinity, and nutrient contents may be regarded as the null hypothesis for oceanographic changes associated with the plate tectonic backtrack path of Site 1241. Significant deviations from the null hypothesis are assumed to reflect temporal changes in regional oceanography that are not related to plate tectonic drift.

In addition, the aging of the oceanic crust below Site 1241 certainly moved the site location into greater water depths between 6 and $2 \mathrm{Ma}$, the time interval examined in this study. Today, Site 1241 is located at a water depth of $2027 \mathrm{~m}$. Considering the subsidence curve for normal oceanic crust (e.g., Parsons and Sclater, 1977), the water depth of Site 1241 was probably $\sim 250 \mathrm{~m}$ shallower at $6 \mathrm{Ma}$ with respect to $2 \mathrm{Ma}$. However, subsidence rates for oceanic crust generated above a plume mantle (e.g., Galapagos hotspot) are expected to be higher than that of normal oceanic crust (e.g., Ito and Clift, 1998). Hence, the water depth of Site 1241 may have deepened by as much as $400 \mathrm{~m}$ between 6 and 2 Ma. As a rough approximation, Site 1241 was located at a water depth of $\sim 1900 \mathrm{~m}$ at $2 \mathrm{Ma}$ and at $\sim 1650-1500 \mathrm{~m}$ at $6 \mathrm{Ma}$. Thus, Site 1241 may
F2. Properties of Site 1241, p. 35.

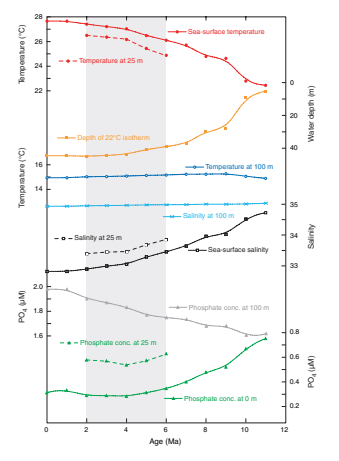

F3. Properties of the upper water column, p. 36.

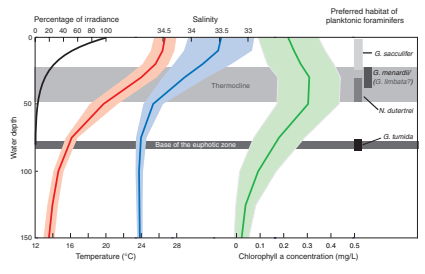


S. STEPH ET AL.

have experienced even better carbonate preservation during the late Miocene.

\section{Strategy}

Past studies demonstrate that the isotopic offset between different species of planktonic foraminifers reflects the temperature range within the photic zone in the tropics (e.g., Ravelo and Fairbanks, 1992; Ravelo and Shackleton, 1995; Cannariato and Ravelo, 1997; Ravelo and Andreasen, 1999; Chaisson and Ravelo, 2000; Faul et al., 2000). The temperature range and thus the isotopic differences in $\delta^{18} \mathrm{O}$ between species are assumed to be large when the thermocline is shallow and small when the thermocline is deep. Because oxygen isotope values are biased by both temperature changes and variations in $\delta^{18} \mathrm{O}_{\text {seawater, }}$ we established $\mathrm{Mg} / \mathrm{Ca}$ records in order to assess the temperature signal and to isolate the $\delta^{18} \mathrm{O}_{\text {seawater }}$ signal from the planktonic $\delta^{18} \mathrm{O}$ records. We also considered the LR04 benthic $\delta^{18} \mathrm{O}$ stack (Lisiecki and Raymo, 2005) to distinguish local changes in $\delta^{18} \mathrm{O}_{\text {seawater }}$ from global variations that resulted from changes in global ice volume. Furthermore, $\delta^{13} \mathrm{C}$ values of planktonic foraminifers were included to evaluate changes in upper ocean water mass signatures. Changes in vertical planktonic $\delta^{13} \mathrm{C}$ gradients are primarily indicative of variations in the nutrient distribution within the upper water column but are, however, not necessarily linked to changes in upper ocean stratification.

In addition to this approach, we also considered variations in the paleoposition of Site 1241, because plate tectonic movement of the Cocos plate significantly displaced Site 1241 northward from its original position at the Galapagos hotspot during the last 11-13 m.y. (Mix, Tiedemann, Blum, et al., 2003).

\section{Selection of Planktonic Foraminifers}

In order to assess vertical gradients in upper ocean water mass signatures, we measured the stable isotope composition and $\mathrm{Mg} / \mathrm{Ca}$ ratios of four planktonic foraminiferal taxa with different habitat depths: Globigerinoides sacculifer (without saclike final chamber), Neogloboquadrina dutertrei (dextral variety), Globorotalia limbata (dextral variety), and Globorotalia tumida (Fig. F4).

The distribution and abundance of planktonic foraminiferal species is strongly related to vertical variations in hydrographic parameters such as temperature, food availability, chlorophyll concentration, and light levels (e.g., Fairbanks et al., 1980, 1982; Fairbanks and Wiebe, 1980; Curry et al., 1983; Ganssen and Sarnthein, 1983; Sautter and Thunell, 1991; Thunell and Sautter, 1992; Ortiz et al., 1995, 1996, 1997; Watkins and Mix, 1998). These factors result in a predictable livingdepth range of different species that can be deciphered by the stable isotope composition of test calcite (Fairbanks and Wiebe, 1980; Ravelo et al., 1990; Ravelo and Fairbanks, 1992; Niebler et al., 1999) (Fig. F3).

G. sacculifer and G. tumida are foraminifers whose calcification depth is considered to be nearly constant within the tropics (e.g., Ravelo and Andreasen, 1999, and references therein). The spinose, symbiont-bearing G. sacculifer has been found living and calcifying within the warm, nutrient-depleted surface mixed layer and upper thermocline (e.g., Fairbanks et al., 1982; Curry et al., 1983). Hence, it mainly records the isotopic composition of near-surface water. However, the adult tests of $G$.
F4. SEM pictures of planktonic foraminifers, p. 37.

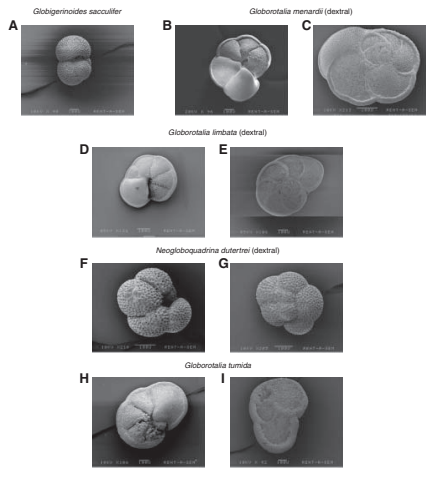


sacculifer include a substantial proportion of gametogenetic calcite that is added slightly deeper in the thermocline and may alter $\delta^{18} \mathrm{O}$ values (e.g., Duplessy et al., 1981; Lohmann, 1995). The isotopic composition of G. tumida reflects hydrographic conditions at the bottom of the photic zone (BOPZ) (Ravelo and Fairbanks, 1992; Ravelo and Shackleton, 1995). This is a nearly constant depth level in tropical waters ( 80$100 \mathrm{~m}$ ). The $\delta^{18} \mathrm{O}$ values and $\mathrm{Mg} / \mathrm{Ca}$ ratios of $G$. tumida are thus primarily considered to register changes in the thermocline depth, because temperature at the BOPZ is partly regulated by the depth of the thermocline. Other species are found at different depth levels within the thermocline, associated with the maximum in chlorophyll concentration and primary productivity (e.g., Curry et al., 1983; Sautter and Thunell, 1991; Ravelo and Fairbanks, 1992; Ravelo and Andreasen, 1999). Thus, their isotopic composition reflects the temperature and chemical composition at the depth of the thermocline as temperature transition layer in a whole. Because thermocline depth may vary through time, the absolute calcification depth of those species cannot be determined from their isotopic composition alone (e.g., Curry et al., 1983; Sutter and Thunell, 1991; Ravelo and Fairbanks, 1992; Ravelo and Andreasen, 1999). When hydrographic conditions change, thermocline-dwelling species may migrate to shallower or deeper levels (e.g., Ravelo and Fairbanks, 1992; Faul et al., 2000). As these species calcify within a steep thermal gradient, only slight changes in the living depth may have a significant influence on the isotopic composition of their tests. We therefore compared stable isotope records of G. limbata (dextral) and N. dutertrei (dextral), two nonspinose, thermocline-dwelling species with presumably overlapping habitat depths, to assess indications of their vertical migration.

Neogloboquadrina dutertrei, the modern representative of the Neogloboquadrinid lineage ( $N$. acostaensis, N. humerosa, and N. dutertrei) (e.g., Parker, 1967; Blow, 1969; Srinivasan and Kennett, 1976) was selected for the time interval from 5.25 to $2.1 \mathrm{Ma}$. N. dutertrei has the tendency to calcify within a narrow temperature range in the tropics (Curry et al., 1983; Ravelo and Fairbanks, 1992; Billups and Spero, 1996; Faul et al., 2000). It inhabits the middle to deep thermocline today, and it is supposed to be closely coupled to the chlorophyll maximum (Fairbanks et al., 1982; Watkins et al., 1998; Spero et al., 2003). Figure F4F and F4G shows the morphotype we commonly used for isotopic and $\mathrm{Mg} / \mathrm{Ca}$ measurements.

G. limbata, a late Miocene to late Pliocene Globorotalia (Menardella) species (e.g., Banner and Blow, 1960; Kennett and Srinivasan, 1983), was chosen to resemble the middle Miocene to modern Globoratalia menardii, because $G$. menardii did not occur in sufficient numbers in the early to middle Pliocene section of Site 1241 (Mix, Tiedemann, Blum, et al., 2003). In the eastern equatorial Pacific, G. menardii today lives within the upper to middle thermocline (Spero et al., 2003). The isotopic offset between G. limbata (dextral) and G. menardii (dextral) appears to be small and relatively constant during the Pliocene, with $\sim 0.11 \%$ o higher $\delta^{13} \mathrm{C}$ values and $\sim 0.15 \%$ higher $\delta^{18} \mathrm{O}$ values of $G$. limbata (Table T1). This is $<1 / 2$ of the short-term variations in downcore records. Although the exact ecological preference of G. limbata remains elusive for the Pliocene, we suggest that G. limbata, like the modern G. menardii, reflects thermocline conditions because the test morphology and isotopic composition of both species is similar.
T1. Isotope values of $G$. limbata (dextral) and G. menardii (dextral), p. 47. 
S. STEPH ET AL.

Tropical East Pacific UpPer OCEAN Stratification

Together, $\mathrm{Mg} / \mathrm{Ca}$ ratios and the stable isotopic composition of the four species used in this study are supposed to reflect the physical and chemical structure of the entire photic zone in the TEP (Fig. F3).

\section{MATERIAL AND METHODS}

We used TEP Site 1241 (Cocos Ridge; $5^{\circ} 50.570^{\prime} \mathrm{N}, 8^{\circ} 26.676^{\prime} \mathrm{W} ; 2027$ $\mathrm{m}$ water depth) for the present study. Because of its shallow water depth, carbonate preservation of foraminiferal tests is good. This is also suggested by comparisons between the sand percentages of the carbonate fraction (indicative of changes in carbonate dissolution/or productivity) and the general pattern of deep Pacific carbonate dissolution (for further discussion see Tiedemann et al., this volume).

The depth interval from 49 to 176 meters composite depth (mcd) (5.7-2.1 Ma) was sampled at a mean distance of $10 \mathrm{~cm}$ above $161 \mathrm{mcd}$ and a mean distance of $15 \mathrm{~cm}$ below. The time resolution of this series is generally better than $3 \mathrm{k} . \mathrm{y}$. (Tiedemann et al., this volume). The samples were freeze-dried and washed through a $63-\mu \mathrm{m}$ mesh. From each sample, 10 well-preserved tests of G. sacculifer (without saclike final chamber) were picked from the 355- to 400- $\mu$ m fraction for stable isotope measurements. From the same size fraction, 10 specimens of $G$. limbata (dextral) and G. tumida were picked from every second sample. As $N$. dutertrei (dextral) is not present in sufficient numbers in the 355to $400-\mu \mathrm{m}$ fraction, we picked $15-20$ specimens from the 250- to 355$\mu \mathrm{m}$ fraction of every second sample. Measurements of G. limbata (dextral) and G. menardii (dextral) were performed on 14 samples where the two coexisted in order to assess the isotopic signature of G. limbata (Table T1). For species determination, we followed the taxonomic concepts of Kennett and Srinivasan (1983).

Isotope analyses were run at IFM-GEOMAR (Kiel, Germany) using a Finnigan Delta-Plus-Advantage mass spectrometer coupled to a Finnigan/Gas Bench II. Precision of the carbonate standard (National Bureau of Standards, NBS-19) over the period of analysis was better than $\pm 0.07 \%$ or for $\delta^{18} \mathrm{O}$ and $\pm 0.05 \%$ for $\delta^{13} \mathrm{C}( \pm 1 \sigma, N=637)$. The isotope values are reported relative to Peedee belemnite (PDB).

Paleotemperatures were reconstructed from $\mathrm{Mg} / \mathrm{Ca}$ ratios of $\mathrm{G}$. sacculifer, G. tumida, N. dutertrei (dextral), and G. limbata (dextral). Twenty to twenty-five specimens ( 0.5-1.2 mg of shell material) were picked from the same size fraction as used for stable isotope measurements if enough specimens were available. For temperature estimation, G. sacculifer was picked from every second sample in the time intervals from 2.1 to $3.7 \mathrm{Ma}$ and 4.8 to $5.5 \mathrm{Ma}$ and from every sample between 3.7 and 4.8 Ma. For samples with low numbers of G. sacculifer, we picked as many as 35 specimens from the $250-$ to $355-\mu \mathrm{m}$ fraction to obtain additional material (see also Groeneveld et al., this volume). We considered one sample per section for $N$. dutertrei and G. tumida, except for two intervals at 4.8 and $2.5 \mathrm{Ma}$, where G. tumida was collected at $10-\mathrm{cm}$ intervals. The average time resolution of these records is better than 45 k.y. For the $\mathrm{Mg} / \mathrm{Ca}$ record of $\mathrm{G}$. limbata, we used one sample every second section, corresponding to a time resolution better than $100 \mathrm{k} . \mathrm{y}$. We avoided specimens visibly contaminated by ferromanganese oxides for $\mathrm{Mg} / \mathrm{Ca}$ analysis. The specimens were gently crushed between glass plates in order to open the chambers. The shell debris was subsequently cleaned according to Barker et al. (2003). Sample treatment includes several rinses with distilled deionized water and methanol (suprapur) 
S. STEPH ET AL.

with ultrasonic treatment between each rinse, two 10-min soaks of the samples in a hot $\left(97^{\circ} \mathrm{C}\right)$ oxidizing $1 \% \mathrm{NaOH} / \mathrm{H}_{2} \mathrm{O}_{2}$ solution $(10 \mathrm{~mL} 0.1$ $\mathrm{N} \mathrm{NaOH}$ [analytical grade] $+100 \mu \mathrm{L} \mathrm{30 \%} \mathrm{H}_{2} \mathrm{O}_{2}$ [suprapur]), a weak acid leach (0.001-M subboiled distilled $\mathrm{HNO}_{3}$ ), and finally, dissolution in subboiled distilled 0.075- $\mathrm{M} \mathrm{HNO}_{3}$. Analyses were performed on the inductively coupled plasma-optical emission spectrometer (ICP-OES) (Ciros CCD SOP, Spectro A.I., Germany) at the Institute of Geosciences, University of Kiel (Germany) (see also Groeneveld et al., this volume).

The conversion of $\mathrm{Mg} / \mathrm{Ca}$ ratios into SSTs was carried out by applying the paleotemperature equation of Anand et al. (2003):

$$
\mathrm{T}=[\log (\mathrm{Mg} / \mathrm{Ca})-\log 0.38] / 0.09
$$

To simplify the visualization of long-term trends, proxy records were smoothed. We used the locally weighted least-squared error method (e.g., Cleveland, 1979) and applied a smoothing factor of $10 \%$, which controls the fraction of the data population considered during smoothing. In comparison to other smoothing methods, this technique is less sensitive to outliers.

The age model of Site 1241 is based on orbital tuning (Tiedemann et al., this volume). The authors used a multiproxy approach, including benthic $\delta^{18} \mathrm{O}$, benthic $\delta^{13} \mathrm{C}$, and percent sand of carbonate fraction records for the correlation of high-frequency variations to the orbital solution of Laskar et al. (1993). The astronomical timescale of Site 1241 is in agreement with that from Atlantic Sites 925 and 926 as indicated by a comparison of benthic $\delta^{13} \mathrm{C}$ records.

\section{RESULTS}

\section{Oxygen Isotope and Mg/Ca Temperature Records}

Oxygen isotope and $\mathrm{Mg} / \mathrm{Ca}$ ratios are shown in the "Appendix," p. 33. Figures F5 and F6 show the Pliocene planktonic $\delta^{18} \mathrm{O}$ and $\mathrm{Mg} / \mathrm{Ca}$ temperature records of $G$. sacculifer $(\mathrm{Mg} / \mathrm{Ca}$ data are presented in Groeneveld et al., this volume; Groeneveld, 2005), G. limbata (dextral), $N$. dutertrei (dextral), and G. tumida from Site 1241. In general, the $\delta^{18} \mathrm{O}$ and $\mathrm{Mg} / \mathrm{Ca}$ temperature offsets between the planktonic foraminiferal species indicate a clear depth ranking consistent with their assumed ecology. The relatively low $\delta^{18} \mathrm{O}$ values and high $\mathrm{Mg} / \mathrm{Ca}$ temperatures of G. sacculifer reflect warmer surface water masses as it calcified predominantly within the surface mixed layer. Generally higher $\delta^{18} \mathrm{O}$ values and lower $\mathrm{Mg} / \mathrm{Ca}$ temperatures of $\mathrm{G}$. tumida result from its deeper habitat at the BOPZ within cooler subsurface waters below the thermocline. The thermocline dwellers $G$. limbata and $N$. dutertrei display intermediate values between those of $G$. sacculifer and G. tumida. Comparisons of long-term trends between $\delta^{18} \mathrm{O}$ and $\mathrm{Mg} / \mathrm{Ca}$ temperatures derived from the same foraminiferal species suggest that the $\delta^{18} \mathrm{O}$ signal was significantly overprinted by variations in $\delta^{18} \mathrm{O}_{\text {seawater }}$ (corresponding to changes in global ice volume and local salinity).

The $\delta^{18} \mathrm{O}$ record of the mixed-layer dweller G. sacculifer (Figs. F5, F6) is marked by a long-term decrease of $\sim 0.8 \%$ from 5.7 to $3.15 \mathrm{Ma}$ with two transient maxima centered at 4.9 and $3.3 \mathrm{Ma}$ (marine isotope stage [MIS] Si6, MIS M2). Both maxima were probably linked to global cooling as suggested by the benthic $\delta^{18} \mathrm{O}$ record of Site 1241 (Tiedemann et
F5. Multispecies planktonic $\delta^{18} \mathrm{O}$ and benthic $\delta^{18} \mathrm{O}$ records, p. 38 .

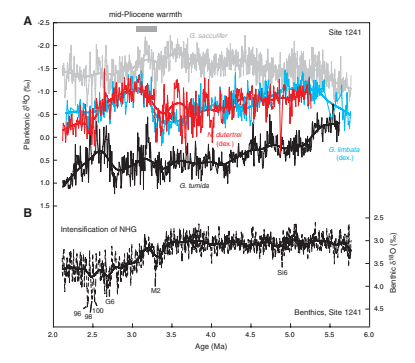

F6. $\delta^{18} \mathrm{O}$ values, $\delta^{18} \mathrm{O}_{\text {seawater, }}$ and $\mathrm{Mg} / \mathrm{Ca}$ temperatures, Site 1241, p. 39.

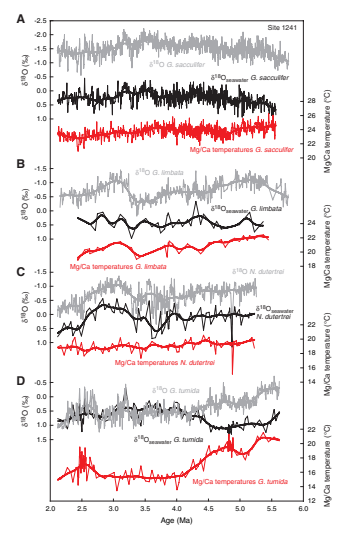


al., this volume) (Fig. F5). We consider the benthic $\delta^{18} \mathrm{O}$ record to reflect mainly global climate changes, as it shows a dynamic that is comparable to global ice volume changes and temperature variability in the source regions of deepwater formation at high latitudes (e.g., Tiedemann et al., 1994; Shackleton et al., 1995; see " $\delta{ }^{18} \mathrm{O}_{\text {seawater }}$ Trends," p. 10). After $3.15 \mathrm{Ma}, \delta^{18} \mathrm{O}$ values of $G$. sacculifer increased by $\sim 0.5 \%$ along with the intensification of NHG. $\delta^{18} \mathrm{O}$ amplitudes increased when first pronounced maxima in glaciation appeared between 2.7 and 2.45 Ma (Tiedemann et al., 1994) (MIS G6-96, see benthic record, Fig. F5). The $\mathrm{Mg} / \mathrm{Ca}$ temperature record of G. sacculifer (Fig. F6) suggests that temperatures fluctuated between $20.9^{\circ}$ and $26.3^{\circ} \mathrm{C}$ with an average of $23.8^{\circ} \mathrm{C}$ from 5.6 to $2.1 \mathrm{Ma}$. As such, surface mixed-layer temperatures at Site 1241 were similar to those observed today in a water depth of $~ 35-$ $40 \mathrm{~m}\left(24.4-23.2^{\circ} \mathrm{C}\right)$ (Conkright et al., 2002). The long-term late Miocene and Pliocene temperature variability is characterized by cooling from 5.6 to $4.7 \mathrm{Ma}$, slight warming from 4.7 to $3.65 \mathrm{Ma}$, cooling from 3.65 to $2.45 \mathrm{Ma}$, followed by warming until $2.1 \mathrm{Ma}$ (for further discussion see Groeneveld et al., this volume). The cooling trend from 5.6 to $4.7 \mathrm{Ma}$ is opposite to the trend observed in the $\delta^{18} \mathrm{O}$ record, as the accompanying decrease in $\delta^{18} \mathrm{O}$ suggests warming rather than cooling. The warming trend from 4.7 to $3.65 \mathrm{Ma}$, however, is in accordance with the continued decrease in $\delta^{18} \mathrm{O}$ values. The cooling trend after $3.65 \mathrm{Ma}$ appears to start at least 200 k.y. earlier than suggested by the G. sacculifer $\delta^{18} \mathrm{O}$ record (Figs. F5, F6) The time interval from 3.2 to $3.1 \mathrm{Ma}$, often referred to as the "mid-Pliocene warmth" (e.g., Crowley, 1996; Raymo et al., 1996), is marked by a pronounced $\delta^{18} \mathrm{O}$ minimum but surprisingly not by a $\mathrm{Mg} / \mathrm{Ca}$ temperature maximum.

The $\delta^{18} \mathrm{O}$ records of the thermocline dwellers G. limbata (dextral) and $N$. dutertrei (dextral) display similar long-term trends, which clearly deviate from the trends observed in the $\delta^{18} \mathrm{O}$ G. sacculifer record (Fig. F5). In contrast to the $\delta^{18} \mathrm{O}$ G. sacculifer record, the $\delta^{18} \mathrm{O}$ values of G. limbata and $N$. dutertrei increased between 5.5 and $3.3 \mathrm{Ma}$ (MIS M2). The strong decrease in $\delta^{18} \mathrm{O}$ of the thermocline dwellers after $3.3 \mathrm{Ma}$, however, is also paralleled by decreasing $\delta^{18} \mathrm{O}$ values of $G$. sacculifer. The following increase in $\delta^{18} \mathrm{O}$ of G. limbata and $N$. dutertrei (after $\sim 3 \mathrm{Ma}$ ) is more pronounced than in the $\delta^{18} \mathrm{O}$ record of $G$. sacculifer and started $\sim 150$ k.y. later. The $\mathrm{Mg} / \mathrm{Ca}$ temperature records of $G$. limbata and $N$. dutertrei differ in absolute values and trends, although their $\delta^{18} \mathrm{O}$ records are similar (Fig. F6). The $\mathrm{Mg} / \mathrm{Ca}$ temperatures of $\mathrm{G}$. limbata were slightly warmer and varied between $18.8^{\circ}$ and $23.2^{\circ} \mathrm{C}$, whereas those of $N$. dutertrei ranged from $17.3^{\circ}$ to $20.5^{\circ} \mathrm{C}$ (except for a short-term temperature minimum at $4.9 \mathrm{Ma}$ ) (Fig. F6). This compares to modern temperatures in a water depth of 40-60 m and 50-70 m, respectively (Conkright et al., 2002). The modern thermocline and chlorophyll maximum, being the preferred habitat of $N$. dutertrei, are located at 30-50 m (Fig. F3). Because temperatures within the modern thermocline are $\sim 22^{\circ} \mathrm{C}$ and the Pliocene mixed-layer temperature was close to the modern one, we assume that the absolute paleotemperature estimates for $N$. dutertrei and G. limbata are slightly too cool. The $\mathrm{Mg} / \mathrm{Ca}$-derived temperature variability of $G$. limbata resembles the long-term variability observed in the $\delta^{18} \mathrm{O}$ record of this species (Figs. F5, F6). In contrast, the temperature record of $N$. dutertrei provides no long-term trend and thus deviates considerably from its recorded $\delta^{18} \mathrm{O}$ variability. Hence, $\delta^{18} \mathrm{O}$ changes display relatively strong variations in salinity because their general trend 
S. STEPH ET AL.

deviates from both the local temperature record and the evolution of global climate as indicated by the benthic $\delta^{18} \mathrm{O}$ record (Figs. F5, F6).

The $\delta^{18} \mathrm{O}$ record of the deep-dweller G. tumida resembles the longterm increase from 5.6 to $3.3 \mathrm{Ma}$ as observed in the $\delta^{18} \mathrm{O}$ records of the thermocline dwellers (Fig. F5). After $3.3 \mathrm{Ma}, \delta^{18} \mathrm{O}$ values of G. tumida decreased into a short-term minimum that represents the time interval of the mid-Pliocene warmth. Thereafter, $\delta^{18} \mathrm{O}$ values increased again, followed by a decrease after $2.75 \mathrm{Ma}$. The succeeding $\delta^{18} \mathrm{O}$ minimum between 2.7 and $2.45 \mathrm{Ma}$ marks an interval that is known to represent first maxima in Pliocene NHG (MIS G6-96) (Fig. F5). Thus, this minimum is very unusual, as benthic and planktonic foraminiferal $\delta^{18} \mathrm{O}$ records generally display pronounced maxima during this period due to global cooling and ice sheet growth. After $2.45 \mathrm{Ma}$, the $\delta^{18} \mathrm{O}$ values of $G$. tumida increased until $2.1 \mathrm{Ma}$. The G. tumida $\mathrm{Mg} / \mathrm{Ca}$ temperatures covary roughly with the trends observed in its $\delta^{18} \mathrm{O}$ record (Fig. F6). At the habitat depth of $G$. tumida, late Miocene and Pliocene temperatures ranged from $13.4^{\circ}$ to $21.5^{\circ} \mathrm{C}$ (Fig. F6). Temperatures decreased by $\sim 6^{\circ} \mathrm{C}$ from 5.4 to $4.0 \mathrm{Ma}$ with major steps at 5.3 and $4.5 \mathrm{Ma}$. From 4.0 to 2.75 $\mathrm{Ma}$, temperatures remained relatively stable and varied between $13.5^{\circ}$ and $17^{\circ} \mathrm{C}$ with an average temperature of $15.3^{\circ} \mathrm{C}$. This is close to modern temperatures at depths of 80-90 m, the modern BOPZ at the position of Site $1241\left(16^{\circ} \mathrm{C}\right)$ (Fig. F3). The $\delta^{18} \mathrm{O}$ minimum during the midPliocene warmth from 3.2 to $3.1 \mathrm{Ma}$ is not characterized by elevated temperatures, and thus presumably reflects a decrease in $\delta^{18} \mathrm{O}_{\text {seawater }}$ The $\delta^{18} \mathrm{O}$ minimum between 2.7 and $2.45 \mathrm{Ma}$, however, can be ascribed to a temperature maximum.

Comparison of long-term trends between $\delta^{18} \mathrm{O}$ and $\mathrm{Mg} / \mathrm{Ca}$ temperature records from the same foraminiferal species clearly demonstrates that the $\delta^{18} \mathrm{O}$ records are not sufficient to reconstruct the thermal structure of the upper water column, because the $\delta^{18} \mathrm{O}$ temperature signal can be fully wiped out by variations in $\delta^{18} \mathrm{O}_{\text {seawater }}$. Such overprints especially affected the $\delta^{18} \mathrm{O}$ records of $G$. sacculifer and $N$. dutertrei. As salinity changes have exerted a more important control on Pliocene TEP upper ocean hydrography than previously assumed (Cannariato and Ravelo, 1997; Chaisson and Ravelo, 2000), we based our interpretations on depth-stratified $\mathrm{Mg} / \mathrm{Ca}$ temperature and $\delta^{18} \mathrm{O}_{\text {seawater }}$ records to assess temporal changes in vertical temperature and salinity gradients.

\section{$\delta^{18} \mathbf{O}_{\text {seawater }}$ Trends}

We combined $\mathrm{Mg} / \mathrm{Ca}$ temperatures and $\delta^{18} \mathrm{O}$ values of each planktonic foraminiferal species in order to calculate the species-related $\delta^{18} \mathrm{O}_{\text {seawater }}$ records according to Shackleton (1974):

$$
\delta^{18} \mathrm{O}_{\text {seawater }}=\delta^{18} \mathrm{O}_{\text {foram }}-21.9+\left(310.6+10 \times \mathrm{SST}_{\mathrm{Mg} / \mathrm{Ca}}\right)^{0.5} .
$$

Figure F7 shows the $\delta^{18} \mathrm{O}_{\text {seawater }}$ records for G. sacculifer, G. limbata (dextral), $N$. dutertrei (dextral), and G. tumida. Changes in $\delta^{18} \mathrm{O}_{\text {seawater }}$ result from variations in global ice volume (sea level) and salinity. To assess local changes in salinity, we considered the LR04 benthic oxygen isotope record of Lisiecki and Raymo (2005) and simply assumed that pronounced short- and long-term variations in $\delta^{18} \mathrm{O}$ reflect, to a certain degree, changes in global ice volume. The LR04 benthic oxygen isotope record represents a $\delta^{18} \mathrm{O}$ stack of 57 globally distributed sites, whereas
F7. $\delta^{18} \mathrm{O}_{\text {seawater }}$ records vs. LR04 benthic $\delta^{18} \mathrm{O}$ stack, p. 40.

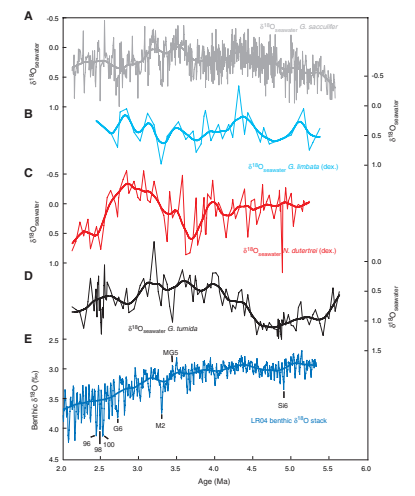


12 records reach back to $4.9 \mathrm{Ma}$ and 5 records cover the time interval from 5 to $5.33 \mathrm{Ma}$. Although the $\delta^{18} \mathrm{O}$ stack contains changes in deepwater temperature and salinity, their local effects are minimized by stacking globally distributed benthic $\delta^{18} \mathrm{O}$ records. At present, however, we cannot quantitatively isolate the contribution of changes in ice volume from the Pliocene $\delta^{18} \mathrm{O}$ amplitudes. For the past 20,000 years, estimates suggest an average global benthic $\delta^{18} \mathrm{O}$ decrease of $1.8 \%$ (Lisiecki and Raymo, 2005), whereas $1.0 \%$ $\pm 0.1 \%$ is attributable to a decrease in global ice volume (Schrag et al., 1996; Shackleton, 2000). This leaves $\sim 0.8 \%$ ( $45 \%$ of the total amplitude) for an increase in deep ocean temperature $\left(\sim 4^{\circ} \mathrm{C}\right)$ that also reflects in some way the warming in high-latitude regions of deepwater formation. During the Pliocene phase of unipolar glaciation from 5.2 to $3.1 \mathrm{Ma}$, the benthic $\delta^{18} \mathrm{O}$ amplitudes are generally lower than $0.5 \%$ and the $\delta^{18} \mathrm{O}$ stack displays no significant long-term trend. We thus simply assume that this interval is characterized by relatively small changes in ice volume and deepwater temperature except for the pronounced benthic $\delta^{18} \mathrm{O}$ increase from 3.49 to 3.3 Ma (MIS MG5 to M2). This short interval may indicate a failed attempt of the climate system to start NHG (Haug and Tiedemann, 1998) that was followed by a climatic rebound representing the mid-Pliocene warmth period (3.2-3.1 Ma) just before the intensification of NHG. From 3.1-2.4 Ma, benthic $\delta^{18} \mathrm{O}$ values increased by $\sim 0.7 \%$ along with the intensification of NHG that was paralleled by a dramatic increase in the supply of ice-rafted debris into the North Atlantic and North Pacific, implying that the Eurasian Arctic and North America were significantly glaciated from 2.75 Ma onward (e.g., Jansen and Sjøholm, 1991; Kleiven et al., 2002). First glacial maxima with $\delta^{18} \mathrm{O}$ amplitudes of $\sim 1 \%$ o occurred in cold stages G6-96 (2.7-2.45 Ma). We assume that the variability of the smoothed benthic LR04 $\delta^{18} \mathrm{O}$ record represents the direction of ice volume changes (Fig. F7). Its comparison with species-related planktonic $\delta^{18} \mathrm{O}_{\text {seawater }}$ records from Site 1241 is used to approximate local long-term changes in salinity. In general, the planktonic $\delta^{18} \mathrm{O}_{\text {seawater }}$ records reveal higher amplitudes and a long-term variability that differs significantly from the benthic $\delta^{18} \mathrm{O}$ record. The smoothed $\delta^{18} \mathrm{O}_{\text {seawater }}$ record for the mixed layer ( $G$. sacculifer) shows a decrease from 5.6 to $3.15 \mathrm{Ma}$, (interrupted by a maximum between 4.1 and 3.7 Ma) (Figs. F6, F7). With respect to the smoothed benthic $\delta^{18} \mathrm{O}$ stack, this trend suggests a decrease in mixed-layer salinity. The increase in mixed-layer $\delta^{18} \mathrm{O}_{\text {seawater }}$ after $3.15 \mathrm{Ma}$ may partly result from an increase in global ice volume associated with the intensification of NHG, rather than reflecting local salinity changes. The $\delta^{18} \mathrm{O}_{\text {seawater }}$ record of the upper thermocline (G. limbata) is relatively similar to that of the mixed layer but lacks the increase in $\delta^{18} \mathrm{O}_{\text {seawater }}$ along with the intensification of NHG. The most striking feature of the $\delta^{18} \mathrm{O}_{\text {seawater }}$ record of the lower thermocline ( $N$. dutertrei) is the pronounced maximum centered at $\sim 3.7 \mathrm{Ma}$, followed by a decrease of $0.9 \%$ until $2.8 \mathrm{Ma}$, and an increase of $0.9 \%$ thereafter. The $\delta^{18} \mathrm{O}_{\text {seawater }}$ minimum around 3 Ma suggests a pronounced mid-Pliocene salinity minimum at the lower thermocline, as it contrasts the progressive increase in global ice volume (Figs. F6, F7). The G. tumida $\delta^{18} \mathrm{O}_{\text {seawater }}$ record is marked by an increase of $\sim 0.5 \%$ between 5.6 and $5.4 \mathrm{Ma}$ and a strong decrease of $\sim 0.7 \%$ from 4.6 to 4.0 $\mathrm{Ma}$, the latter suggesting a salinity decrease at the BOPZ. Relatively low values persisted until $3.1 \mathrm{Ma}$ and then $\delta^{18} \mathrm{O}_{\text {seawater }}$ increased along with the intensification of NHG (Figs. F6, F7). 
S. STEPH ET AL.

In summary, the planktonic $\delta^{18} \mathrm{O}_{\text {seawater }}$ records deviate significantly from Pliocene changes in global ice volume and thus imply strong salinity changes within the upper water column of the TEP. This finding contradicts the general assumption that variations in $\delta^{18} \mathrm{O}$ salinity play a minor role for interpreting TEP planktonic $\delta^{18} \mathrm{O}$ records (Cannariato and Ravelo, 1997; Chaisson and Ravelo, 2000).

\section{Vertical Temperature and $\delta^{\mathbf{1 8}} \mathbf{O}_{\text {seawater }}$ Gradients}

Pliocene changes in vertical temperature and $\delta^{18} \mathrm{O}_{\text {seawater }}$ gradients within the photic zone at Site 1241 provide information about changes in TEP upper ocean stratification, including the depth of the thermocline and the structure of the pycnocline. A great advantage of temperature and $\delta^{18} \mathrm{O}_{\text {seawater }}$ gradients between different planktonic foraminiferal species is that they eliminate global temperature and $\delta^{18} \mathrm{O}_{\text {seawater }}$ changes.

The $\mathrm{Mg} / \mathrm{Ca}$ temperature estimates for G. sacculifer (mixed layer), $G$. limbata, N. dutertrei (thermocline), and G. tumida (BOPZ), as well as the $\mathrm{Mg} / \mathrm{Ca}$ temperature differences between $G$. sacculifer and deep-dwelling foraminifers, are shown in Figure F8B and F8C, respectively. We regard temperature differences between $G$. sacculifer and G. tumida $\left(\Delta T_{\text {G.sacculifer- }}\right.$ c.tumida) as most suitable for monitoring changes in thermocline depth, because the habitat of these two species is considered to be relatively constant within the tropics (e.g., Ravelo and Andreasen, 1999) (see "Selection of Planktonic Foraminifers," p. 5). From 5.6 to $4.8 \mathrm{Ma}$, $\Delta T_{\text {G.sacculifer-C.tumida }}$ is lowest $\left(3.5^{\circ}-5.5^{\circ} \mathrm{C}\right)$, implying a relatively deep thermocline. The temperature difference significantly increased from 4.8 to $4.0 \mathrm{Ma}$ (to $\sim 9^{\circ} \mathrm{C}$ ) mainly due to the temperature decrease of $\sim 6^{\circ} \mathrm{C}$ at the BOPZ (Fig. F8B, F8C). This change in the thermal structure of the upper water column points to an early Pliocene shoaling of the TEP thermocline, as a shallower thermocline results in shoaling and compression of the isotherms in the upper water column. From 3.6 to $2.7 \mathrm{Ma}$, $\Delta T_{\text {G.sacculifer-G.tumida }}$ decreased again (Fig. F8C). This decrease was mainly caused by mixed-layer cooling (see also Groeneveld et al., this volume), whereas temperatures at the BOPZ remained relatively stable (Fig. F8B). The pronounced $\Delta T_{\text {G.sacculfer-G.tumida }}$ minimum at $\sim 2.5 \mathrm{Ma}$, however, resulted from warming at the BOPZ. This points to a short-term deepening of the thermocline that parallels first pronounced maxima in NHG as inferred from benthic $\delta^{18} \mathrm{O}$ records (Figs. F5, F7).

The temperature records of the thermocline-dwelling foraminifers $G$. limbata and $N$. dutertrei can be biased by habitat changes, as these species may migrate to shallower or deeper habitats when the thermocline shallows or deepens, respectively. The temperature record of the upper thermocline dweller G. limbata reflects the early Pliocene subsurface cooling trend recorded by G. tumida (Fig. F8B), although less pronounced $\left(\sim 2.5^{\circ} \mathrm{C}\right)$ and more gradual $(5.3-3.3 \mathrm{Ma})$. This led to an increase in the temperature gradient between mixed-layer and upper thermocline $\left(\Delta T_{\text {G.sacculifer-G.limbata }}\right)$ from $\sim 2^{\circ}$ to $\sim 4.5^{\circ} \mathrm{C}$ (Fig. F8C). After 3.3 Ma, $\Delta T_{\text {G.sacculifer-G.limbata }}$ decreased due to warming of the upper thermocline $(\sim 3.3-3 \mathrm{Ma})$ and cooling of the mixed layer. At the lower thermocline ( $N$. dutertrei), however, temperatures were comparatively stable during the Pliocene (5.3-2.1 Ma). Accordingly, the temperature gradient between mixed-layer and lower thermocline $\left(\Delta T_{\text {G.sacculifer-N.dutertrei }}\right)$ was relatively constant. Small changes in Pliocene $\Delta T_{\text {G.sacculifer-N.dutertrei }}$ mainly resulted from changing mixed-layer temperatures.
F8. $\mathrm{Mg} / \mathrm{Ca}$ ratios and habitat water temperatures, p. 41.

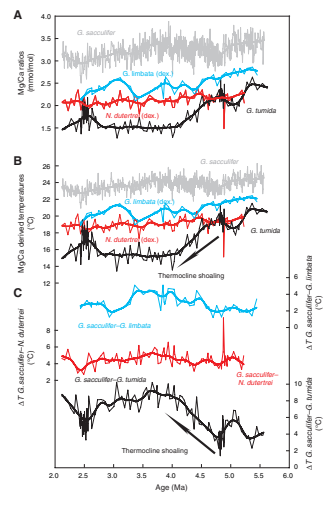


S. STEPH ET AL.

The observed changes in thermal structure are partly reflected by changes in vertical salinity gradients. Figure $\mathbf{F} 9$ shows the $\delta^{18} \mathrm{O}_{\text {seawater }}$ records for each foraminiferal species, as well as the $\delta^{18} \mathrm{O}_{\text {seawater }}$ differences between deep-dwelling foraminifers and G. sacculifer. The pattern of salinity change between $G$. sacculifer and G. tumida is similar to changes in $\Delta T_{\text {G.sacculifer-G.tumida. }}$. In general, increases in the temperature gradient between the mixed layer and the BOPZ are associated with de-

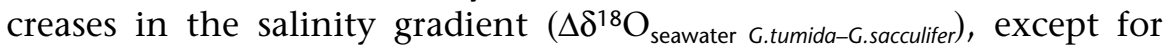
two intervals at $\sim 5.5$ and $2.5 \mathrm{Ma}$. From 5.6 to $5.4 \mathrm{Ma}, \Delta \delta^{18} \mathrm{O}_{\text {seawater G.tumida- }}$ G.sacculifer increased. Between 5.4 and $4.8 \mathrm{Ma}, \Delta \delta^{18} \mathrm{O}_{\text {seawater G.tumida-G.sacculifer }}$ was highest (as high as $1 \%$ ), whereas salinity within the mixed layer was lower than at the BOPZ. The maximum difference of $1 \%$ would correspond to a salinity difference of 2 when applying the global $\delta^{18} \mathrm{O}_{\text {seawater }}$ salinity relationship of Broecker (1989). This salinity difference is close to the modern one (Fig. F3). Along with the early Pliocene shoaling of the thermocline (4.8-4.0 Ma), $\delta^{18} \mathrm{O}_{\text {seawater }}$ at the BOPZ (G. tumida) decreased by $\sim 0.8 \%$ (Fig. F9A). This resulted in a $\Delta \delta^{18} \mathrm{O}_{\text {seawater G.tumida-G.sacculifer }}$ of only $\sim 0.2 \%$ after $4.0 \mathrm{Ma}$ (Fig. F9B), which differed significantly from the modern one.

The $\delta^{18} \mathrm{O}_{\text {seawater }}$ records of $G$. sacculifer and G. limbata were relatively similar throughout the Pliocene (Fig. F9A) and indicate similar salinities in the mixed layer and upper thermocline (Fig. F9B). We neglect the maximum in $\Delta \delta^{18} \mathrm{O}_{\text {seawater G.limbata-G.sacculifer }}$ between 5.0 and $4.5 \mathrm{Ma}$, as it is only based on two data points. The comparison of $\delta^{18} \mathrm{O}_{\text {seawater }}$ records between G. sacculifer, N. dutertrei, and G. tumida provides an unusual result (Fig. F9) as it suggests low salinities at the lower thermocline and higher salinities above and below (except for the intervals from $\sim 3.8-3.4 \mathrm{Ma}$ and $\sim 2.5-2.1 \mathrm{Ma}$ ). Such a scenario is not very likely, because salinity at the lower thermocline should be on a mixing line between lower salinities within the mixed layer and higher salinities at the BOPZ (Fig. F9). Hence, the $\delta^{18} \mathrm{O}_{\text {seawater }}$ gradients may be partly afflicted with uncertainties that result from the application of the $\mathrm{Mg} / \mathrm{Ca}$ temperature equation (see "Discussion," p. 15).

\section{Carbon Isotope Trends}

Pliocene variations in foraminiferal $\delta^{13} \mathrm{C}$ include global shifts related to interactions between terrestrial and oceanic carbon reservoirs and local shifts created by changes in nutrient supply, utilization, and remineralization of organic matter. We use the benthic $\delta^{13} \mathrm{C}$ record of Site 1241 (Tiedemann et al., this volume; Fig. F10A) to approximate global changes, as benthic $\delta^{13} \mathrm{C}$ records from the central east Pacific are a reasonable indicator for shifts in the whole ocean carbon budget (Mix et al., 1995). Figure F10A compares the planktonic $\delta^{13} \mathrm{C}$ records from Site 1241 with the benthic $\delta^{13} \mathrm{C}$ record. From 5.7 to $3.3 \mathrm{Ma}$, all planktonic $\delta^{13} \mathrm{C}$ records were roughly parallel to each other and followed the general trend of the benthic $\delta^{13} \mathrm{C}$ record. During this time interval, the planktonic $\delta^{13} \mathrm{C}$ records largely reflect variations in the global carbon reservoir on orbital and tectonic timescales. Between 3.3 and $2.1 \mathrm{Ma}$, the $\delta^{13} \mathrm{C}$ record of $G$. sacculifer and the benthic $\delta^{13} \mathrm{C}$ record remained parallel, indicating that surface mixed-layer water masses still reflected global changes in $\delta^{13} \mathrm{C}_{\text {seawater }}$ In contrast, the $\delta^{13} \mathrm{C}$ records of deeperdwelling foraminifers show a gradual increase of $0.5 \%$ after $3.3 \mathrm{Ma}$ (MIS M2) that deviates from the benthic $\delta^{13} \mathrm{C}$ trend (Fig. F10A). This
F9. $\delta^{18} \mathrm{O}_{\text {seawater }}$ at habitat depths, Site 1241, p. 42.

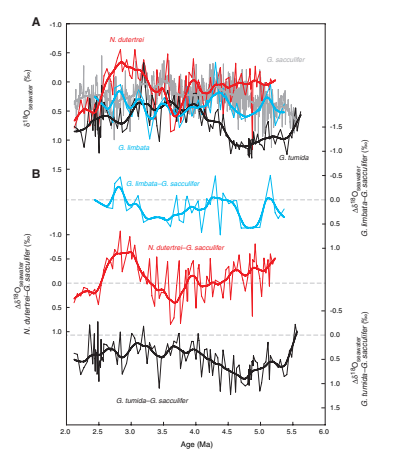

F10. $\delta^{13} \mathrm{C}$ records of planktonic foraminifers, Site 1241, p. 43.

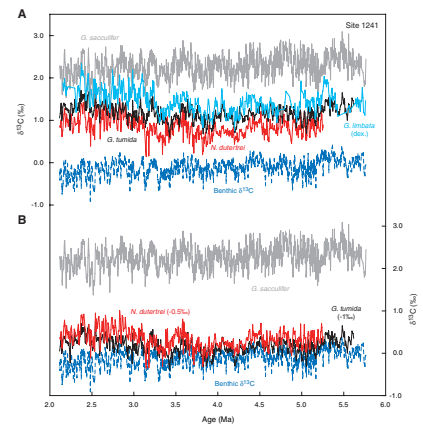


S. STEPH ET AL.

shift to higher $\delta^{13} \mathrm{C}$ values within the thermocline and at the BOPZ points to local changes in nutrient supply or utilization.

Further information about local changes in vertical nutrient gradients within the upper water column is provided by $\delta^{13} \mathrm{C}$ gradients between shallow- and deep-dwelling planktonic foraminifers, as these gradients eliminate the global $\delta^{13} \mathrm{C}$ variability. Because Site 1241 was located outside the equatorial upwelling region during the Pliocene, $\delta^{13} C_{\text {DIC }}$ (DIC = dissolved inorganic carbon) is expected to decrease with increasing water depth. Phytoplankton elevates surface $\delta^{13} C_{D I C}$ as it discriminates against ${ }^{13} \mathrm{CO}_{2}$ during photosynthesis, and heterotrophic organisms reintroduce ${ }^{13} \mathrm{C}$-depleted $\mathrm{CO}_{2}$ back into the DIC pool via respiration at depth (Kroopnick, 1974; Spero et al., 2003). It is thus commonly assumed that the most positive $\delta^{13} \mathrm{C}$ values correspond to the nutrient-depleted surface mixed layer and that the lowest $\delta^{13} \mathrm{C}$ values occur at greater depths, where the nutrient supply and recycling is highest. The depth-related nutrient increase from the surface to the BOPZ is illustrated in Figure F2.

In general, our results support this assumption, as carbon isotopic values of the mixed-layer dweller G. sacculifer are higher than those of $N$. dutertrei (dextral), G. limbata (dextral), and G. tumida. $\delta^{13} \mathrm{C}$ gradients between $G$. sacculifer and the deep dwellers are as large as $2 \%$, and are thus comparable to the modern vertical $\delta^{13} C_{\text {DIC }}$ gradient observed within the Panama Basin (Fairbanks et al., 1982). However, it is difficult to assess vertical Pliocene gradients in $\delta^{13} \mathrm{C}$, as the species-specific offsets to $\delta^{13} \mathrm{C}_{\mathrm{DIC}}$ are not well constrained. Analyses of shells from plankton tows and core tops suggest that $\delta^{13} \mathrm{C}$ values of medium-sized G. sacculifer are close to $\delta^{13} C_{D I C}$ of ambient seawater, whereas larger specimens $(>500 \mu \mathrm{m})$ are enriched in ${ }^{13} \mathrm{C}$ and thus display larger deviations (e.g., Mulitza et al., 1999). No information exists for the extinct species $G$. limbata. We assume that the habitat of G. limbata is comparable to that of $G$. menardii (which exists since the middle Miocene) as the $\delta^{13} \mathrm{C}$ values of G. limbata have a small and relatively constant offset of approximately $+0.11 \%$. Unfortunately, core-top $\delta^{13} \mathrm{C}$ values of $G$. menardii have no consistent $\Delta \delta^{13} \mathrm{C}_{\text {shell-DIC }}$ offset (Ravelo and Fairbanks, 1995; Mielke, 2001). For $N$. dutertrei, Mulitza et al. (1999) found a $\Delta \delta^{13} C_{\text {shell-DIC }}$ offset of $+0.5 \%$ determined on South Atlantic specimens from plankton tows. G. tumida $\delta^{13} \mathrm{C}$ values from three Atlantic core-top samples suggest an offset of $+1 \%$ with respect to $\delta^{13} \mathrm{C}_{\mathrm{DIC}}$ (Ravelo and Fairbanks, 1995). ACcordingly, the $\delta^{13} \mathrm{C}$ record of $G$. tumida would exhibit the lowest $\delta^{13} \mathrm{C}$ values (Fig. F10B) as expected due to its habitat at the BOPZ. The vertical $\delta^{13} \mathrm{C}$ gradients between $G$. sacculifer, $N$. dutertrei, and G. tumida remained relatively constant from 5.6 to $3.3 \mathrm{Ma}$ and indicate no significant change in nutrient supply, utilization, and remineralization. However, the $\delta^{13} \mathrm{C}$ increase after 3.3 Ma (MIS M2) that was only recorded by the deep-dwelling planktonic foraminifers suggests a decrease in nutrients below the mixed layer. 


\section{DISCUSSION}

\section{Pliocene Changes in the Thermal Structure of the TEP Upper Water Column and Possible Links to Tectonics and Climate}

$\mathrm{Mg} / \mathrm{Ca}$ temperature records of shallow- and deep-dwelling planktonic foraminifers from Site 1241 provide new insights into Pliocene changes in the thermal structure of the TEP upper water column. In general, the $\mathrm{Mg} / \mathrm{Ca}$ temperature estimates are in good agreement with the assumed ecological preferences of each foraminiferal species, as $\mathrm{Mg}$ / Ca temperatures decrease with increasing habitat depth (Figs. F6, F8B).

In order to assess whether the observed long-term temperature variations reflect the plate tectonic drift of Site 1241 or local dynamics of ocean circulation, we considered the modern temperature distribution along the site's backtrack path (Figs. F1, F2). Under modern hydrographic conditions, the northeastward drift of Site 1241 between 6 and $2 \mathrm{Ma}$ would result in a temperature increase of $\sim 1.5^{\circ} \mathrm{C}$ within the mixed layer, no temperature change at the BOPZ, and a slight deepening of the thermocline $(\sim 5 \mathrm{~m})$. None of these trends is registered by our temperature reconstructions for the upper $100 \mathrm{~m}$ of the water column. This is not surprising, as the proposed drift-induced changes in the thermal structure are very small. We thus mainly interpret the observed temperature variability as a consequence of global climate change and/or local changes in surface hydrography.

The most striking change in the thermal structure of the upper water column was the early Pliocene shoaling of the thermocline. This is indicated by an increase in the temperature gradient between the mixed layer (G. sacculifer) and the BOPZ (G. tumida) from $\sim 4^{\circ}$ to $\sim 9^{\circ} \mathrm{C}$ between 4.8 and 4.0 Ma (Fig. F8C). The subsurface cooling trend was also registered by the upper thermocline-dweller G. limbata, resulting in an increase in the temperature gradient between mixed layer and upper thermocline from $\sim 2.0^{\circ}$ to $\sim 4.5^{\circ} \mathrm{C}$ between 5.3 and $3.3 \mathrm{Ma}$ (Fig. F8C). The Pliocene shoaling of the thermocline was also observed at TEP Site 851 by the study of Cannariato and Ravelo (1997), although they based their interpretation on $\delta^{18} \mathrm{O}$ records from G. sacculifer and G. tumida. Their suggestion that the planktonic $\delta^{18} \mathrm{O}$ records mainly reflect variations in temperature is not confirmed by our results for the lower thermocline dwellers $N$. dutertrei and $N$. humerosa. At Site 1241, the Mg/Caderived temperatures from $N$. dutertrei remained comparatively stable from 5.3 to $2.1 \mathrm{Ma}$ and suggest that relatively strong variations in $\delta^{18} \mathrm{O}$ mainly reflect changes in salinity (see " $\delta^{18} \mathrm{O}_{\text {seawater }}$ Trends," p. 10). It was previously suggested that $N$. dutertrei generally calcifies close to the same temperature, regardless of oceanographic changes (e.g., Curry et al., 1983; Ravelo and Fairbanks, 1992; Billups and Spero, 1996). Our record provides for the first time the opportunity to document such a temperature adaptation for the Pliocene. Although the early Pliocene thermocline shoaling should have caused a migration of $N$. dutertrei to a shallower habitat, we surmise that temperatures within the lower thermocline would not vary strongly if thermocline depth decreases, as long as SST remains relatively stable. During the time interval prior to $4.8 \mathrm{Ma}$, temperatures at the lower thermocline level were similar to those at the BOPZ (Fig. F8B). After $4.8 \mathrm{Ma}$, as a result of the thermocline shoaling, higher temperatures within the lower thermocline than at the 
S. STEPH ET AL.

BOPZ indicate that a comparatively warm thermocline prevailed above the BOPZ (Fig. F8B).

The early Pliocene thermocline shoaling was completed by $\sim 4.0 \mathrm{Ma}$ and documents a new stage in the thermal structure of the TEP upper water column that persisted until $\sim 2.7 \mathrm{Ma}$. During this time interval, slight thermal modifications mainly resulted from a gradual cooling of the mixed layer by $\sim 1^{\circ} \mathrm{C}$ between 3.65 and $2.7 \mathrm{Ma}$. Between 2.7 and 2.5 $\mathrm{Ma}$, the temperature gradient between mixed layer and BOPZ decreased significantly as a result of continued cooling of the mixed layer and warming of $\sim 3^{\circ} \mathrm{C}$ at the BOPZ (Fig. F8B, F8C). The subsurface warming suggests a short-term deepening of the thermocline, probably in response to the intensification of NHG and the development of significant cyclic variations in global ice volume after $2.75 \mathrm{Ma}$, as inferred from benthic $\delta^{18} \mathrm{O}$ records (Figs. F5, F7). This finding contradicts the most recent assumption that tropical climate was relatively stable during the mid-Pliocene intensification of global cooling (Ravelo et al., 2004).

Considering our temperature estimates as reasonable, we suggest that the thermal structure of the upper water column between 4.0 and 2.7 Ma was already close to the modern one (Fig. F3). In this context, of course, the application of $\mathrm{Mg} / \mathrm{Ca}$ temperature equations is a point of discussion. In this study, the temperature estimates are based on the multispecies approach of Anand et al. (2003). The application of other $\mathrm{Mg} / \mathrm{Ca}$ temperature equations, however, would modify our results significantly, as summarized in Table $\mathbf{T} 2$.

Applying the species-specific temperature equation of Nürnberg et al. (2000) for G. sacculifer results in $\sim 1^{\circ} \mathrm{C}$ warmer mixed-layer temperatures (on average $\sim 24.8^{\circ} \mathrm{C}$ ) than using the multispecies equation of Anand et al. (2003). This corresponds to modern temperatures at $\sim 30$ - to $35-\mathrm{m}$ water depth. Although this warmer temperature estimate may be more realistic, applying the Anand et al. (2003) equation for all species reduces problems arising from the extracted $\delta^{18} \mathrm{O}_{\text {seawater }}$ records (see "Salinity Changes within the TEP Upper Water Column," p. 19).

The application of species-related G. sacculifer and N. dutertrei temperature equations from Dekens et al. (2002) for the Pacific results in nearly identical temperatures for both species, with average temperatures of $\sim 26.8^{\circ} \mathrm{C}$ that are $\sim 3^{\circ} \mathrm{C}$ higher than our estimates for G. sacculifer. Assuming a relatively deep thermocline, and taking into account that $N$. dutertrei may have lived within the mixed layer as G. sacculifer did, the $\delta^{18} \mathrm{O}$ offset between both species (up to $1.5 \%$ ) would suggest extreme salinity differences at approximately the same water depth, which we regard as unrealistic (Fig. F5). The Atlantic equation from Dekens et al. (2002) provides temperature estimates for G. sacculifer that are similar to those derived from the Nürnberg et al. (2000) equation. Their species-related Atlantic equation for $N$. dutertrei provides $\sim 2.5^{\circ} \mathrm{C}$ warmer temperatures than our estimates for $N$. dutertrei with an average temperature of $\sim 21.5^{\circ} \mathrm{C}$ that is close to the modern average thermocline temperature $\left(\sim 22^{\circ} \mathrm{C}\right)$. As there is no species-specific equation for G. limbata, however, the application of the Atlantic equation for $N$. dutertrei is problematic. Using the Atlantic equation of Dekens et al. (2002) for $N$. dutertrei and the multispecies equation of Anand et al. (2003) for G. limbata provide $\sim 0.5^{\circ}-1^{\circ} \mathrm{C}$ higher temperatures for the lower thermocline than for the upper thermocline, although the $\mathrm{Mg} / \mathrm{Ca}$ values of $N$. dutertrei are generally lower than those of G. limbata. Therefore, we refrain from mixing formulas of different authors and use the Anand et al. (2003) equation.
T2. Comparison of different $\mathrm{Mg} /$ Ca paleotemperature equations, p. 48. 
S. STEPH ET AL.

The multispecies temperature equation of Elderfield and Ganssen (2000) leads to generally lower temperatures for all habitats: $5.5^{\circ} \mathrm{C}$ cooler for $G$. sacculifer, $5^{\circ} \mathrm{C}$ cooler for G. limbata, $5^{\circ} \mathrm{C}$ cooler for $N$. dutertrei, and $5^{\circ} \mathrm{C}$ cooler for $G$. tumida. The temperature gradient within the upper water column, however, is close to that derived from the Anand et al. (2003) equation. We regard the temperature estimates derived from the Elderfield and Ganssen (2000) equation as too cool, as it is not likely that mixed-layer temperatures $\left(\sim 18.5^{\circ} \mathrm{C}\right)$ were significantly cooler than modern ones $\left(\sim 24^{\circ} \mathrm{C}\right)$ during the Pliocene, a period when Earth's climate was generally warmer than today. These comparisons demonstrate the recent uncertainty in estimating absolute temperatures from planktonic $\mathrm{Mg} / \mathrm{Ca}$ ratios (Table $\mathrm{T} 2$ ). Including the calculation of planktonic $\delta^{18} \mathrm{O}_{\text {seawater }}$ into the process of interpretation (associated relative changes in the salinity) suggests the Anand et al. (2003) equation as the best approach when calculating temperatures for various planktonic foraminiferal species (see "Salinity Changes within the TEP Upper Water Column," p. 19).

Possible forcing mechanisms that come into question concerning the Pliocene development of the thermal structure of the TEP upper water column are manifold. The long-term shoaling of the thermocline from 4.8 to $4.0 \mathrm{Ma}$ and the gradual cooling of the mixed layer since $3.65 \mathrm{Ma}$ imply slow forcing mechanisms. This suggests tectonic processes like the constriction of tropical gateways and mountain uplift as well as high-latitude processes like development of the Northern Hemisphere ice cap, possibly coupled to a reduction in atmospheric $\mathrm{CO}_{2}$, as major candidates.

As the tropical Pacific is bordered by the IG to the west and by the CAS to the east, it is likely that changes in the configuration of these low-latitude gateways left a significant imprint on its surface hydrography. Although the timing of the constriction of the IG remains speculative, it was suggested that major changes in west Pacific surface hydrography associated with the constriction of the IG occurred during the middle to late Miocene and possibly close to the Pliocene/Pleistocene boundary (e.g., Hamilton, 1979; Kennett et al., 1985; Chaisson, 1995). More recently, Cane and Molnar (2001) and Molnar and Cane (2002) suggested that the constriction of the IG after 5.0-3.0 Ma may have played a major role in climate change during the Pliocene by strengthening Walker Circulation over the Pacific and the trans-Pacific thermocline slope. These changes are consistent with shoaling of the thermocline in the east Pacific and with gradual cooling in the mixed layer.

The timing of the stepwise changes in the thermocline shoaling, however, also suggests a close link to a critical threshold in the closure history of the CAS. Between 4.6 and $4.2 \mathrm{Ma}$, surface water exchange between the Pacific and the Caribbean became significantly restricted (Keigwin, 1982; Haug et al., 2001; Steph et al., in press). This is paralleled by a major step in subsurface cooling at Site 1241 after $4.5 \mathrm{Ma}$ (Fig. F8B). The relationship between the emergence of the CAS and hydrographic changes in the TEP is still a matter of debate. In case of an open isthmus, general circulation model results predict a $10 \mathrm{~Sv}$ (Sverdrup: 1 $\mathrm{Sv}=10^{6} \mathrm{~m}^{3} / \mathrm{s}$ ) flow of low-saline NECC waters from the Pacific into the Caribbean as a result of the higher Pacific sea level (Maier-Reimer et al., 1990). This is opposed by only $1 \mathrm{~Sv}$ of wind-driven surface water flow from the Caribbean into the Pacific. It was previously assumed that the inflow of warm, saline Caribbean surface water masses possibly main- 
S. STEPH ET AL.

tained a deep thermocline in the east Pacific before the final closure of the CAS (Farrell et al., 1995). Although the exact timing of the final closure is still arguable, it did not occur significantly earlier than $2.7 \mathrm{Ma}$ (e.g., Lundelius, 1987; Kameo and Sato, 2000). Accordingly, we do not expect that the wind-driven inflow of Caribbean surface waters into the Pacific ceased between 5 and $4 \mathrm{Ma}$, thereby causing significant thermocline shoaling in the TEP.

More recently, however, numerical model results provided a global mechanism that may link the early Pliocene thermocline shoaling in the Pacific to changes in the configuration of the CAS. Oceanographers suggested that changes in the rate of North Atlantic Deep Water (NADW) production may trigger global adjustments of the thermocline depth (e.g., Huang et al., 2000). The signal is carried from ocean to ocean by Kelvin and Rossby waves, inducing an upward (downward) movement of the main thermocline, when NADW formation is strong (weak). For example, model results predicted a thermocline shoaling of $50 \mathrm{~m}$ in the Pacific for a 10-Sv increase in NADW formation. Indeed, considerable evidence from proxy data and modeling studies addressing the consequences of the closure of the CAS points to an increase in NADW production after 4.6 Ma (e.g., Maier-Reimer et al., 1990; Mikolajewicz and Crowley, 1997; Haug and Tiedemann, 1998; Haug et al., 2001; Nisancioglu et al., 2003; Prange and Schulz, 2004). Strengthening of NADW formation after the restriction of surface water exchange (4.6 Ma) may have facilitated the early Pliocene shoaling of the thermocline in the TEP.

In addition, progressive shoaling of the CAS was suggested to trigger changes in atmospheric circulation, such as a strengthening of Walker Circulation over the Pacific and changes in the trade wind strength that might have influenced Pacific surface current systems and the structure of the upper water column, as suggested by Hovan (1995), Cannariato and Ravelo (1997), Billups et al. (1999), and Chaisson and Ravelo (2000). Closure-induced warming of the Caribbean basins after 4.6-4.4 Ma (Steph et al., in press) may have caused development of a pressure contrast between the western tropical Atlantic and the eastern tropical Pacific (Chaisson and Ravelo, 2000). This in turn was suggested to have strengthened Walker Circulation over the tropical Pacific and increased the west-east thermocline tilt (Chaisson and Ravelo, 2000). Model results indicate an increase in steric height within the WPWP region after closure of the CAS (Maier-Reimer et al., 1990). A large hydraulic head in the WPWP due to more effective piling up of warm surface waters may have increased the volume and velocity of the eastward-flowing EUC (Maier-Reimer et al., 1990) that today transports relatively cool, highsalinity waters into the TEP at the thermocline level. This may have contributed to shoaling of the thermocline as well.

Moreover, support for an early Pliocene southward shift of the ITCZ comes from studies that investigated Atlantic and Pacific changes in tropical wind field and surface hydrography (Hovan, 1995; Farrell et al., 1995; Cannariato and Ravelo, 1997; Chaisson and Ravelo, 1997; Norris, 1998; Billups et al., 1998, 1999). Similar to the modern seasonal cycle, a shift to a more southern position of the ITCZ in the TEP would have weakened the southeast trades and thus significantly reduced the strength of the NECC and the SEC. A decrease in the return flow of warm water from the WPWP and a strengthened EUC thus may have allowed the observed thermocline shoaling in the TEP and in turn triggered development of stronger tropical Pacific east-west gradients (Cannariato and Ravelo, 1997; Chaisson and Ravelo, 2000). In addition, 
S. STEPH ET AL.

this scenario is expected to cool the TEP mixed layer, which however, is not observed before $3.65 \mathrm{Ma}$ at Site 1241 (Figs. F6, F8B) (see Groeneveld et al., this volume). Reconstructions of Pliocene-Pleistocene transequatorial mixed-layer temperatures suggest that the modern eastwest temperature gradient did not develop before 1.5 Ma (Wara et al., 2005). Hence, it is not clear to what extent this mechanism may have contributed to shoaling of the thermocline during the early Pliocene.

\section{Salinity Changes within the TEP Upper Water Column}

At Site 1241, the Pliocene variability of species-related planktonic $\delta^{18} \mathrm{O}_{\text {seawater }}$ can be attributed to a large part to local salinity changes as these records partly deviate significantly from the evolution of global ice volume as deduced from comparisons with the benthic $\delta^{18} \mathrm{O}$ stack (Lisiecki and Raymo, 2005) (Fig. F7). In addition, the variability of $\delta^{18} \mathrm{O}_{\text {seawater }}$ gradients between different foraminiferal habitat depths, a measure that eliminates the global $\delta^{18} \mathrm{O}$ ice volume signal, suggests considerable regional salinity changes within the upper $100 \mathrm{~m}$ of the water column (Fig. F7). Hence, Pliocene variations in TEP salinity appear to have been significantly larger than previously assumed (Cannariato and Ravelo, 1997; Chaisson and Ravelo, 2000; Wara et al., 2005).

Determining if these variations reflect either the plate tectonic drift of Site 1241 or local changes in $\delta^{18} \mathrm{O}_{\text {seawater }}$ of the upper ocean layer can roughly be assessed by consideration of modern oceanographic conditions and associated salinity changes along the site's backtrack path (Figs. F1, F2). Under modern conditions, the northeastward drift of Site 1241 (6-2 Ma) would have resulted in a salinity decrease of $\sim 0.5$ within the mixed layer and relatively stable and higher salinities at the BOPZ. Consequently, this would imply an increase in the salinity gradient between the mixed layer and the BOPZ from 6 to $2 \mathrm{Ma}$ (Fig. F2). Indeed, the early Pliocene decrease in $\delta^{18} \mathrm{O}_{\text {seawater }}$ of $G$. sacculifer points to a salinity decrease within the mixed layer. In contrast, the expected increase of the salinity gradient within the upper water column is not observed (Fig. F9). We thus infer that salinity changes at Site 1241 reflect to a large part local variances, possibly triggered by changes in the precipitation/evaporation ratio, variations in thermocline depth, displacements of subsurface currents at or below the thermocline level, or salinity changes in the source regions of subsurface currents.

Considering an ice volume correction (assuming that the long-term increase in the LR04 benthic $\delta^{18} \mathrm{O}$ stack [Lisiecki and Raymo, 2005] mainly reflects the intensification of Northern Hemisphere ice sheet growth), mixed-layer salinities decreased gradually from 5.6 to $2 \mathrm{Ma}$ (see Groeneveld et al., this volume). At first glance, this decrease would be in conformance with the northeastward drift of Site 1241. Nearly identical Pliocene mixed-layer $\delta^{18} \mathrm{O}$ values at TEP Sites 1241 and 851, however, argue against plate tectonic drift as the major trigger for salinity changes. If the northward paleodrift of Site 1241 led to decreasing mixed-layer salinities, we would expect the development of a $\delta^{18} \mathrm{O} G$. sacculifer gradient between sites as drift-induced salinity changes were presumably smaller at Site 851 that moved predominantly westward along the NECC/SEC boundary (Fig. F1; see "Regional Variations in TEP Upper Ocean Signatures," p. 22). As both sites document similar evolution, it is likely that regional changes in the precipitation/evaporation ratio contributed to decreasing mixed-layer salinities in the TEP. Such changes may have also resulted from an increase in the precipita- 
S. STEPH ET AL.

tion/evaporation ratio within the WPWP, as low-salinity waters are carried into the east Pacific by the NECC. Another, and more simple, explanation for the salinity decrease may relate to the Pliocene shoaling and closure of the CAS. The relative freshening at Site 1241 may not just be due to changes in atmospheric water vapor transport (Jousaumme et al., 1986) but to a decrease in the oceanic export of freshwater from the Pacific into the Atlantic.

During the early Pliocene, changes in vertical salinity gradients were closely linked to thermocline shoaling. At $\sim 5.5 \mathrm{Ma}$, when a deep thermocline probably prevailed below the BOPZ as indicated by the temperature records of $G$. tumida and $N$. dutertrei, the salinity gradient between mixed layer (G. sacculifer) and BOPZ (G. tumida) was very small. This is consistent with a thick mixed layer that extended to the habitat of $G$. tumida. Subsequent shoaling of the mixed layer between 5.5 and $4.8 \mathrm{Ma}$ is inferred from the development of a pronounced $\delta^{18} \mathrm{O}_{\text {seawater }}$ gradient between G. sacculifer and G. tumida. If the thermocline shallowed to a depth level above the BOPZ and stratification in the upper water column enhanced, it is not very likely that low-salinity surface waters were mixed down to the BOPZ. The major step in thermocline shoaling between 4.8 and $4.0 \mathrm{Ma}$, however, was not associated with a further increase in the salinity gradient. Instead, $\Delta \delta^{18} \mathrm{O}_{\text {seawater }}$ ( $G$. tumida-G. sacculifer) decreased, mainly caused by a salinity decrease at the BOPZ, whereas salinity at the thermocline level remained comparatively stable (Fig. F9). This argues more for a salinity decrease in the source regions of subsurface currents than for freshening from the sea surface. Along with the thermocline shoaling, we expect a strengthened influence of the EUC on subsurface water masses (e.g., Maier-Reimer et al., 1990; Chaisson and Ravelo, 2000). As salinity of the EUC today is slightly higher than that of the surrounding subsurface waters, strengthening of the EUC should have resulted in a salinity increase of subsurface waters rather than a salinity decrease (as observed) unless the source region of the EUC was marked by low salinities during this time. The relatively small $\delta^{18} \mathrm{O}_{\text {seawater }}$ gradient between the mixed layer and BOPZ $(<0.5 \%)$ persisted until $2.1 \mathrm{Ma}$.

In spite of a relatively stable salinity gradient between the mixed layer and BOPZ, significant modifications in $\delta^{18} \mathrm{O}_{\text {seawater }}$ mark the lower thermocline level after $4.0 \mathrm{Ma}$. Strong variations in the $\delta^{18} \mathrm{O}_{\text {seawater }}$ record of $N$. dutertrei point to a salinity maximum centered at $3.7 \mathrm{Ma}$ and a pronounced salinity minimum at $\sim 3 \mathrm{Ma}$ that comprises the midPliocene warmth period (Fig. F7). In contrast, salinity within the upper thermocline (G. limbata) remained comparatively stable (Fig. F7). The salinity changes at the lower thermocline level after 4.0 Ma were neither observed in the mixed layer nor at the BOPZ, but the strong salinity decrease between 3.7 and 3.0 Ma was associated with a $\delta^{13} \mathrm{C}$ shift toward higher values (lower nutrient contents) in the deep-dwelling foraminifers after 3.3 Ma (see "Carbon Isotope Trends," p. 13). This interrelation suggests changes in the source regions of thermocline water masses as a possible steering mechanism for the salinity changes.

However, the interpretation of $\delta^{18} \mathrm{O}_{\text {seawater }}$ records from different foraminiferal species is biased by uncertainties resulting from $\mathrm{Mg} / \mathrm{Ca}$ temperature calculations (Table T2). We regard the species-specific longterm evolution of $\delta^{18} \mathrm{O}_{\text {seawater }}$ as reliable, because the trends are independent from the application of different $\mathrm{Mg} / \mathrm{Ca}$ temperature equations. Of course the use of different $\mathrm{Mg} / \mathrm{Ca}$ temperature equations for one species affects absolute $\delta^{18} \mathrm{O}_{\text {seawater }}$ estimates. Consequently, the calculation of 
S. STEPH ET AL.

habitat-related $\delta^{18} \mathrm{O}_{\text {seawater }}$ gradients is afflicted with even larger uncertainties. The $\delta^{18} \mathrm{O}_{\text {seawater }}$ gradient between G. sacculifer and G. tumida is considered as most credible, as differences between their habitat depths are largest. None of the existing paleotemperature equations, including different combinations of $G$. sacculifer-specific equations, led to reversed $\delta^{18} \mathrm{O}_{\text {G. tumida-G. sacculifer }}$ gradients. In contrast, $\delta^{18} \mathrm{O}_{\text {seawater }}$ gradients between $G$. sacculifer and thermocline dwellers are more problematic, as temperature differences between these species are much smaller. Application of the Anand et al. (2003) multispecies equation for all foraminiferal species used in this study provides the physically most realistic salinity distribution within the upper water column. We are, however, still faced with a problem concerning the $\delta^{18} \mathrm{O}_{\text {seawater }}$ record of $N$. dutertrei. Comparatively low $\delta^{18} \mathrm{O}_{\text {seawater }}$ values of $N$. dutertrei temporarily point to salinities at the lower thermocline that are lower than those within the mixed layer and the BOPZ (Fig. F9). Compared to the modern structure of the upper water column at Site 1241, this is not very likely, as salinity should increase with increasing water depth (Fig. F3).

Mixing temperature equations from different authors could easily result in reversals of $\delta^{18} \mathrm{O}_{\text {seawater }}$ gradients between adjacent habitats. The combined application of available $\mathrm{Mg} / \mathrm{Ca}$ paleotemperature equations in combination with $\delta^{18} \mathrm{O}$ on core-top samples and comparisons with the modern salinity and temperature pattern may help to identify the most realistic combination of habitat-related temperature equations.

\section{$\delta^{13}$ C-Shift in Tropical Pacific Subsurface Waters after 3.3 Ma}

The most striking feature of the planktonic $\delta^{13} \mathrm{C}$ records at Site 1241 is the gradual increase of $0.5 \%$ recorded by all deep dwellers after 3.33.2 Ma (MIS M2) (Fig. F10). This increase is neither reflected in the global signal of the benthic $\delta^{13} \mathrm{C}$ record nor in the $\delta^{13} \mathrm{C}$ of the mixed-layer dweller G. sacculifer at Site 1241. The plate tectonic drift of Site 1241 provides no clue to explain the observed pattern. Under modern conditions, the northeastward drift of Site 1241 (6-2 Ma) would suggest increasing nutrient concentrations at the $\mathrm{BOPZ}$ and no significant change in the mixed layer. In contrast, the Pliocene $\delta^{13} \mathrm{C}$ increase below the mixed layer that was also observed at TEP Site 851 (Cannariato and Ravelo, 1997) suggests relatively stable nutrient concentrations at the BOPZ prior to $3.3 \mathrm{Ma}$ and a decrease in nutrient concentrations at the BOPZ after 3.3 Ma.

The timing of this shift is closely linked to the first cooling steps of the intensification of NHG. As similar changes were also observed in a deep-dweller record from the western tropical Pacific (Whitman and Berger, 1993), it is likely that the $\delta^{13} \mathrm{C}$ increase is a regional phenomenon affecting the entire tropical Pacific thermocline, rather than resulting from local changes in upper ocean nutrient cycling.

Accordingly, Cannariato and Ravelo (1997) interpreted the increase in tropical Pacific thermocline ventilation to indicate nutrient depletion in the high-latitude source region of the upwelled intermediate water. The Southern Ocean is thought to be an important source for tropical thermocline ventilation, as intermediate water masses formed in high latitudes become entrained into the thermocline on their way north and feed the EUC near the equator (Toggweiler et al., 1991). Paleoceanographic studies demonstrated that the tropical thermocline $\delta^{13} \mathrm{C}$ signal partly originates in high latitudes and is transferred to the low- 
latitude thermocline as a preformed signal (Oppo and Fairbanks, 1989; McKenna et al., 1995; Ninnemann and Charles, 1997; Spero and Lea, 2002; Spero et al., 2003). Antarctic Intermediate Water (AAIW) and Subantarctic Mode Water (SAMW) provide the necessary conduit by which these two areas are linked, as first suggested by Oppo and Fairbanks (1989). The intermediate water is injected into the thermocline at the northern edge of the Antarctic Circumpolar Current and moves northward, becoming entrained in and transported to the east by the EUC. In a general sense, the tropical thermocline dweller $N$. dutertrei may therefore record changes in the Pliocene nutrient and carbon isotopic chemistry of waters at the Polar Front and/or Subantarctic Front, as the source of the EUC is derived from SAMW/AAIW (Toggweiler et al., 1991; Loubere, 2000, 2001). Spero and Lea (2002) and Spero et al. (2003), for instance, interpreted Pleistocene $\delta^{13} \mathrm{C}$ records of $N$. dutertrei near the Galapagos Islands to reflect high-latitude $\delta^{13} \mathrm{C}$ changes.

Recently, Carter et al. (2004) suggested more, shallower, and faster intermediate water flow at the Canterbury Drift in the southwest Pacific after 3.25 Ma. They attributed these changes to development of the Subantarctic Front and/or to an enhanced formation of SAMW. To detect possible links between Pliocene changes in $\delta^{13} \mathrm{C}$ signatures of southeast Pacific AAIW and the $\delta^{13} \mathrm{C}$ increase within the tropical Pacific thermocline at $\sim 3.3 \mathrm{Ma}$, we compared the $\delta^{13} \mathrm{C}$ record of the thermocline dwelling foraminifer $N$. dutertrei from Site 1241 to the benthic $\delta^{13} \mathrm{C}$ record of Site 1236 (Tiedemann et al., this volume) (Fig. F11). Today, Site 1236 is located on the Nazca Ridge in a water depth of $1323 \mathrm{~m}$. During the early Pliocene, it may have been a few hundred meters shallower as a result of its subsidence history (Mix, Tiedemann, Blum, et al., 2003). The relatively shallow depth of the site makes it suitable for monitoring intermediate water chemistry in the open ocean. From 5.3 to $2.3 \mathrm{Ma}$, high benthic $\delta^{13} \mathrm{C}$ values $(0 \% 0-0.8 \%$ ) at Site 1236 indicate the presence of AAIW. However, the $\delta^{13} \mathrm{C}$ signature of AAIW indicates no major change after $3.3 \mathrm{Ma}$. It is thus unlikely that the Pliocene $\delta^{13} \mathrm{C}$ shift within the tropical Pacific thermocline monitored by $N$. dutertrei at Site 1241 was transferred to the tropics by AAIW formed in the southeast Pacific sector of the Southern Ocean. If Pliocene changes in Southern Ocean intermediate water composition can account for the observed changes in ventilation of the tropical Pacific thermocline, their source either derived from the shallower SAMW component of intermediate waters or the source region was located in the high-latitude southwest Pacific and was marked by different preformed $\delta^{13} \mathrm{C}$ values. As the factors that control the $\delta^{13} \mathrm{C}$ signal of planktonic foraminifers are manifold (see "Carbon Isotope Trends," p. 13), additional productivity proxies would have to be taken into account for a more detailed interpretation of changes in upper ocean nutrient contents.

\section{Regional Variations in TEP Upper Ocean Signatures}

The modern TEP is marked by pronounced climatic and oceanographic gradients over only a few degrees of latitude (Fig. F1). To examine regional variations in Pliocene TEP upper ocean signatures, we compared planktonic stable isotope records from Site 1241 with those from Site 851 (Cannariato and Ravelo, 1997). Today, Site 851 is located $\sim 3^{\circ}$ south of Site 1241 and $\sim 26^{\circ}$ farther west. Site 1241 lies within the relatively warm, low-salinity waters of the NECC, whereas Site 851 is positioned at the NECC/SEC boundary with the EUC in its subsurface.
F11. Site $1241 \delta^{13} \mathrm{C}$ record of $N$. dutertrei vs. Site 1236 benthic $\delta^{13} \mathrm{C}$ record, p. 44.

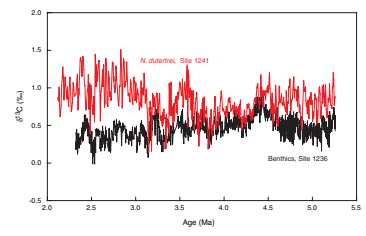


About 6 m.y. ago, the position of Site 1241 was $~ 2.5^{\circ}$ farther south and Site 851 was located $\sim 0.5^{\circ}$ farther south, as suggested by their tectonic backtrack paths (Duncan and Clague, 1985; Pisias et al., 1995; Mix, Tiedemann, Blum, et al., 2003) (Fig. F1). Over the past 6 m.y., Site 1241 moved farther away from the equatorial upwelling region into the center of the NECC, whereas Site 851 remained close to the SEC/NECC boundary (Fig. F1). Therefore, latitudinal differences in upper ocean hydrography between both sites may have left an imprint in more recent times. On the other hand, differences in planktonic $\delta^{18} \mathrm{O}$ and $\delta^{13} \mathrm{C}$ between Sites 1241 and 851 may indicate longitudinal changes in upper ocean water mass signatures, possibly in response to the progressive closure of the CAS.

Figures F5, F12, and F13 compare the planktonic stable isotope records of Sites 1241 (5.7-2.1 Ma) and 851 (5.0-2.0 Ma). The use of similar size fractions of $G$. sacculifer and $G$. tumida for stable isotope analyses at Sites 1241 and 851 (Cannariato and Ravelo, 1997) allows for direct comparisons of absolute $\delta^{18} \mathrm{O}$ and $\delta^{13} \mathrm{C}$ values. We did not directly compare the $N$. dutertrei record of Site 1241 with the $N$. dutertrei/N. humerosa record of Site 851 because of uncertainties concerning speciesspecific and size-related isotopic offsets between the two sites.

Comparisons of G. sacculifer $\delta^{18} \mathrm{O}$ and $\delta^{13} \mathrm{C}$ records indicate that surface mixed-layer conditions were almost identical at both sites between 5.0 and 2.1 Ma with respect to the error range of the analyses and stratigraphic uncertainties (Figs. F12A, F13A). Assuming that temperature differences between the two sites did not play a significant role, this implies that both sites were located within similar mixed-layer water masses. Accordingly, warm, low-salinity waters of the NECC probably reached slightly farther south during the early Pliocene. If the SEC exerted a major control on both sites during the late Miocene and early Pliocene, the northward drift of Site 1241 should have resulted in the development of a $\delta^{18} \mathrm{O}$ gradient between sites, which is not observed. In addition, the absence of this gradient does not endorse an influence from high salinity Caribbean surface waters entering the Pacific through the CAS. The early Pliocene shoaling of the gateway and its closure during the late Pliocene should have produced a gradient, if a significant inflow of Caribbean surface waters existed. Vice versa, the Pliocene shoaling of the CAS may have resulted in a reduced export of relatively low salinity Pacific water masses into the Atlantic, which led to a relative freshening in the tropical eastern Pacific. This could explain the observed Pliocene $\delta^{18} \mathrm{O}_{\text {G.sacculifer }}$ decrease at both sites (also suggested by the $\delta^{18} \mathrm{O}_{\text {seawater }}$ trend at Site 1241). Whether an increase in the precipitation/evaporation ratio contributed to the tropical freshening remains elusive.

Small regional $\delta^{18} \mathrm{O}$ and $\delta^{13} \mathrm{C}$ differences between Sites 851 and 1241 occurred at the BOPZ (Figs. F12B, F13B). Although both G. tumida records reflect the early Pliocene $\delta^{18} \mathrm{O}$ increase due to the shoaling of the thermocline, the $\delta^{18} \mathrm{O}$ values of $G$. tumida were generally lower at the more western Site 851 before $4.2 \mathrm{Ma}$ (Fig. F12B). This suggests either higher temperatures or lower salinities at the BOPZ at Site 851, possibly associated with a slightly deeper thermocline due to longitudinal variations in upper ocean hydrography. This is consistent with the modern thermocline tilt. After $4.2 \mathrm{Ma}$, the $\delta^{18} \mathrm{O}$ records of $G$. tumida display no significant differences between both sites.

The $\delta^{13} \mathrm{C}$ values of $G$. tumida were enriched by as much as $0.5 \%$ at Site 851 with respect to Site 1241 during the interval between 4.5 and
F12. Planktonic $\delta^{18} \mathrm{O}$ records from Sites 1241 and 851, p. 45.

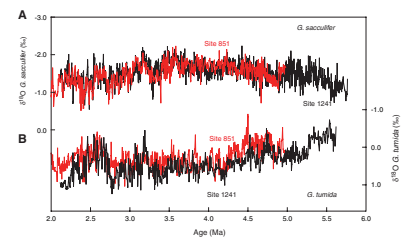

F13. Planktonic $\delta^{13} \mathrm{C}$ records from Sites 1241 and 851, p. 46.

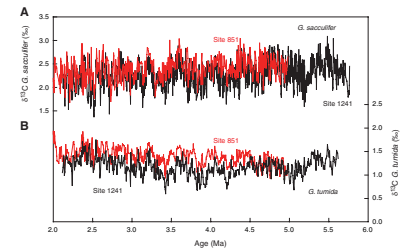


S. STEPH ET AL.

2.1 Ma (Fig. F13B). This may be related to the northward drift of Site 1241 out of the influence of the EUC. The EUC is marked by lower nutrient contents in comparison to more northern water masses at similar water depths (Fig. F2).

\section{SUMMARY AND CONCLUSIONS}

In comparison to other planktonic stable isotope studies that examined the Pliocene TEP (Cannariato and Ravelo, 1997), this study provides both $\mathrm{Mg} / \mathrm{Ca}$ temperature estimates and stable isotope records from shallow- and deep-dwelling planktonic foraminifers that span the time interval from $\sim 5.7$ to $2.1 \mathrm{Ma}$. This allows differentiation between temperature and salinity changes in the upper water column and sheds new light on variations in the thermal structure of the TEP upper water column. The main conclusions include the following:

1. In general, Pliocene $\delta^{18} \mathrm{O}$ and $\mathrm{Mg} / \mathrm{Ca}$ temperature offsets between planktonic foraminiferal species (G. sacculifer, G. limbata [dextral], N. dutertrei [dextral], and G. tumida) indicate a clear depth ranking consistent with their assumed ecology. $\delta^{18} \mathrm{O}_{\text {seawater }}$ estimates for the upper water column suggest a stronger variability in local salinity than previously assumed. However, it has to be mentioned that species-specific temperature estimates vary significantly when applying different $\mathrm{Mg} / \mathrm{Ca}$ temperature equations. Consequently, the calculation of habitat-related temperature and $\delta^{18} \mathrm{O}_{\text {seawater }}$ gradients is afflicted with even larger uncertainties. We consider gradients between $G$. sacculifer and $G$. tumida as most reliable because differences between their habitat depths are largest.

2. The earliest Pliocene (5.6-4.8 Ma) was marked by a deep thermocline, as temperatures at the BOPZ were similar to those at the lower thermocline. This relatively stable configuration was, however, accompanied by the development of an increasing salinity gradient between the mixed layer and the BOPZ, inferred from the $\delta^{18} \mathrm{O}_{\text {seawater }}$ gradient between G. sacculifer and G. tumida.

3. The most pronounced Pliocene change in TEP upper ocean stratification was the shoaling of the thermocline from 4.8 to $4.0 \mathrm{Ma}$, when mixed-layer temperatures and salinities remained relatively constant in contrast to a pronounced temperature $\left(\sim 6^{\circ} \mathrm{C}\right)$ and salinity decrease at the BOPZ. This change led to a new state in the thermal structure of the TEP, as the thermocline remained relatively shallow until 2.1 Ma. The early Pliocene shoaling of the thermocline was probably associated with a reorganization of TEP surface water circulation in response to tropical gateway dynamics (IG and CAS). The timing of the shoaling, however, suggests a link to the critical threshold in the closure history of the CAS that significantly restricted Caribbean-Pacific surface water exchange between 4.6 and $4.2 \mathrm{Ma}$.

4. Temperatures within the lower thermocline remained relatively stable $\left(18^{\circ}-19^{\circ} \mathrm{C}\right)$ throughout the Pliocene as indicated by the $\mathrm{Mg} / \mathrm{Ca}$ temperature record of $N$. dutertrei. The upper thermocline dweller G. limbata, however, suggests larger temperature variability than $N$. dutertrei. We thus assume that the habitat of $N$. dutertrei is more strictly coupled to the thermocline depth than that of G. limbata. 
S. STEPH ET AL.

5. Regional variations in Pliocene TEP upper ocean hydrography were weak, as indicated by the comparison of planktonic stable isotope records from Sites 1241 and 851. The similarity of their G. sacculifer $\delta^{18} \mathrm{O}$ and $\delta^{13} \mathrm{C}$ records implies that both sites were affected by the same surface water masses from 5 to $2.1 \mathrm{Ma}$. This was most likely the NECC, as no latitudinal gradients developed between the two sites when Site 1241 moved out of the SEC/ NECC boundary and the equatorial upwelling region.

6. The $\delta^{13} \mathrm{C}$ increase in deep-dweller records of Sites 1241 and 851 (Cannariato and Ravelo, 1997) after 3.3-3.2 Ma was previously interpreted to reflect changes in the source region of high-latitude intermediate waters that feed the EUC and the tropical Pacific thermocline (Cannariato and Ravelo, 1997). The timing of this shift parallels an increase and a shoaling of intermediate water flow close to New Zealand after 3.25 Ma (Carter et al., 2004). However, these changes in $\delta^{13} \mathrm{C}$ were not registered in the benthic $\delta^{13} \mathrm{C}$ record from intermediate water Site 1236, reflecting AAIW signatures from the southeast Pacific sector of the Southern Ocean.

\section{ACKNOWLEDGMENTS}

We like to thank J. Schönfeld, H. Kinkel, L. Reuning, and M. Regenberg for stimulating discussions and criticism at different stages of this study. The manuscript benefited significantly from the suggestions of two anonymous reviewers and W.F. Ruddiman. We also thank W.P. Chaisson and A. Holbourn for help with species determination, $\mathrm{H}$. Kinkel for providing scanning electron microscope pictures, and U. Nielsen, A. Jesußek, L. Haxhiaj, and S. Koch for technical assistance. We thank the crew of the JOIDES Resolution and the Leg 202 science party for an exceptionally successful expedition. This research used samples and data provided by the Ocean Drilling Program (ODP). ODP is sponsored by the U.S. National Science Foundation (NSF) and participating countries under management of Joint Oceanographic Institutions (JOI), Inc. It was performed within the DFG Research Unit FOR 451 (Impact of Gateways on Ocean Circulation, Climate and Evolution; funding under Ti240/12). 


\section{REFERENCES}

Anand, P., Elderfield, H., and Conte, M., 2003. Calibration of Mg/Ca thermometry in planktonic foraminifera from a sediment trap time series. Paleoceanography, 18(2):1050. doi:10.1029/2002PA000846

Banner, F.T., and Blow, W.H., 1960. Some primary types of species belonging to the superfamily Globigerinaceae. Cushman Found. Foraminiferal Res. Contrib., 11 (Pt. $1): 1-41$.

Barker, S., Greaves, M., and Elderfield, H., 2003. A study of cleaning procedures used for foraminiferal $\mathrm{Mg} / \mathrm{Ca}$ paleothermometry. Geochem., Geophys., Geosyst., 4. doi:10.1029/2003GC000559

Berger, W.H., and Wefer, G., 1996. Central themes of South Atlantic circulation. In Wefer, G., Berger, W.H., Siedler, G., and Webb, D.J. (Eds.), The South Atlantic: Present and Past Circulation: Berlin (Springer-Verlag), 1-11.

Berggren, W.A., and Hollister, C.D., 1974. Paleogeography, paleobiogeography, and the history of circulation of the Atlantic Ocean. In Hay, W.W. (Ed.), Sudies in Paleooceanography. Spec. Publ.-Soc. Econ. Paleontol. Mineral., 20:126-186.

Billups, K., Ravelo, A.C., and Zachos, J.C., 1998. Early Pliocene deep water circulation in the western equatorial Atlantic: implications for high-latitude climate change. Paleoceanography, 13:84-95.

Billups, K., Ravelo, A.C., Zachos, J.C., and Norris, R.D., 1999. Link between oceanic heat transport, thermohaline circulation, and the Intertropical Convergence Zone in the early Pliocene Atlantic. Geology, 27:319-322. doi:10.1130/00917613(1999)027<0319:LBOHTT>2.3.CO;2

Billups, K., and Spero, H.J., 1996. Reconstructing the stable isotope geochemistry and paleotemperatures of the equatorial Atlantic during the last 150,000 years: results from individual foraminifera. Paleoceanography, 11:217-238. doi:10.1029/ 95PA03773

Blow, W.H., 1969. Late middle Eocene to recent planktonic foraminiferal biostratigraphy. In Brönnimann, P., and Renz, H.H. (Eds.), Proc. First Int. Conf. Planktonic Microfossils, Geneva, 1967: Leiden (E.J. Brill), 1:199-422.

Broecker, W.S., 1989. The salinity contrast between the Atlantic and Pacific Oceans during glacial time. Paleoceanography, 4:207-212.

Bryden, H.L., and Brady, E.C., 1985. Diagnostic model of the three-dimensional circulation in the upper Equatorial Pacific Ocean. J. Phys. Oceanogr., 15:1255-1273. doi:10.1175/1520-0485(1985)015<1255:DMOTTD>2.0.CO;2

Cane, M.A., and Molnar, P., 2001. Closing of the Indonesian Seaway as a precursor to East African aridification around 3-4 million years ago. Nature (London, U. K.), 411:157-162. doi:10.1038/35075500

Cannariato, K.G., and Ravelo, A.C., 1997. Pliocene-Pleistocene evolution of the eastern Pacific surface water circulation and thermocline depth. Paleoceanography, 12:805-820. doi:10.1029/97PA02514

Carter, R.M., Fulthorpe, C.S., and Lu, H., 2004. Canterbury drifts at Ocean Drilling Program Site 1119, New Zealand: climatic modulation of southwest Pacific intermediate water flows since 3.9 Ma. Geology, 32:1005-1008. doi:10.1130/G20783.1

Chaisson, W., 1995. Planktonic foraminiferal assemblages and paleoceanographic change in the trans-tropical Pacific Ocean: a comparison of west (Leg 130) and east (Leg 138), latest Miocene to Pleistocene. In Pisias, N.G., Mayer, L.A., Janecek, T.R., Palmer-Julson, A., and van Andel, T.H. (Eds.), Proc. ODP, Sci. Results, 138: College Station, TX (Ocean Drilling Program), 555-597.

Chaisson, W.P., and Ravelo, A.C., 1997. Changes in upper water-column structure at Site 925, late Miocene-Pleistocene: planktonic foraminifer assemblage and isotopic evidence. In Shackleton, N.J., Curry, W.B., Richter, C., and Bralower, T.J. (Eds.), Proc. ODP, Sci. Results, 154: College Station, TX (Ocean Drilling Program), 255-268. [PDF] 
Chaisson, W.P., and Ravelo, A.C., 2000. Pliocene development of the east-west hydrographic gradient in the equatorial Pacific. Paleoceanography, 15:497-505. doi:10.1029/1999PA000442

Cleveland, W.S., 1979. Robust locally weighted regression and smoothing scatterplots. J. Am. Stat. Assoc., 74:829-836.

Coates, A.G., Collins, L.S., Aubry, M.-P., and Berggren, W.A., 2004. The geology of the Darien, Panama, and the late Miocene-Pliocene collision of the Panama arc with northwestern South America. Geol. Soc. Am. Bull., 116:1327-1344.

Coates, A.G., Jackson, J.B.C., Collins, L.S., Cronin, T.M., Dowsett, H.J., Bybell, L.M., Jung, P., and Obando, J.A., 1992. Closure of the Isthmus of Panama: the near-shore marine record of Costa Rica and western Panama. Geol. Soc. Am. Bull., 104:814828.

Collins, L.S., Coates, A.G., Berggren, W.A., Aubry, M.-P., and Zhang, J., 1996. The late Miocene Panama isthmian strait. Geology, 24:687-690. doi:10.1130/00917613(1996)024<0687:TLMPIS >2.3.CO;2

Conkright, M.E., Locarnini, R.A., Garcia, H.E., O’Brien, T.D., Boyer, T.B., Stephens, C., and Antonov, J.I., 2002. World Ocean Atlas 2001: Objective Analyses, Data Statistics, and Figures [CD-ROM]: Silver Spring, MD (National Oceanographic Data Center).

Curry, W.B., Thunell, R.C., and Honjo, S., 1983. Seasonal changes in the isotopic composition of planktonic foraminifera collected in Panama Basin sediment traps. Earth Planet. Sci. Lett., 64:33-43. doi:10.1016/0012-821X(83)90050-X

Crowley, T.J., 1996. Pliocene climates: the nature of the problem. Mar. Micropaleontol., 27:3-12.

Dekens, P.S., Lea, D.W., Pak, D.K., and Spero, H.J., 2002. Core top calibration of $\mathrm{Mg} /$ $\mathrm{Ca}$ in tropical foraminifera: refining paleotemperature estimation. Geochem., Geophys., Geosyst., 3(4). doi:10.1029/2001GC000200

Delcroix, T., Eldin, G., and Hénin, C., 1987. Upper ocean water masses and transports in the western tropical Pacific $\left(165^{\circ} \mathrm{E}\right)$. J. Phys. Oceanogr., 17:2248-2262. doi:10.1175/1520-0485(1987)017<2248:UOWMAT>2.0.CO;2

Donguy, J.R., and Meyers, G., 1996. Mean annual variation of transport of major currents in the tropical Pacific Ocean. Deep-Sea Res., Part I, 43:1105-1122. doi:10.1016/0967-0637(96)00047-7

Dowsett, H., Barron, J., and Poore, R., 1996. Middle Pliocene sea surface temperatures: a global reconstruction. Mar. Micropaleontol., 27:13-25. doi:10.1016/03778398(95)00050-X

Dowsett, H., Thompson, R., Barron, J., Cronin, T., Fleming, F., Ishman, S., Poore, R., Willard, D., and Holtz, T., Jr., 1994. Joint investigations of the middle Pliocene climate I: PRISM paleoenvironmental reconstructions. Global Planet. Change, 9:169195. doi:10.1016/0921-8181(94)90015-9

Dowsett, H.J., Cronin, T.M., Poore, R.Z., Thompson, R.S., Whatley, R.C., and Wood, A.M., 1992. Micropaleontological evidence for increased meridional heat transport in the North Atlantic Ocean during the Pliocene. Science, 258:1133-1135.

Driscoll, N.W., and Haug, G.H., 1998. A short circuit in thermohaline circulation: a cause for Northern Hemisphere glaciation? Science, 282:436-438. doi:10.1126/science.282.5388.436

Duncan, R.A., and Clague, D.A., 1985. Pacific plate motion recorded by linear volcanic chains. In Nairn, A.E.M., Stehli, F.G., and Uyeda, S. (Eds.), The Ocean Basins and Margins (Vol. 7A): The Pacific Ocean: New York (Plenum), 89-121.

Duplessy, J.-C., Blanc, P.-L., and Bé, A.W.H., 1981. Oxygen-18 enrichment of planktonic foraminifera due to gametogenic calcification below the euphotic zone. Science, 213:1247-1250.

Duque-Caro, H., 1990. Neogene stratigraphy, paleoceanography and paleobiogeography in northwest South America and the evolution of the Panama Seaway. Palaeogeogr., Palaeoclimatol., Palaeoecol., 77:203-234. doi:10.1016/0031-0182(90)90178-A 
Elderfield, H., and Ganssen, G., 2000. Past temperature and $\delta^{18} \mathrm{O}$ of surface ocean waters inferred from foraminiferal $\mathrm{Mg} / \mathrm{Ca}$ ratios. Nature (London, U. K.), 405:442445. doi:10.1038/35013033

Enfield, D.B., and Lee, S.-K., 2005. The heat balance of the Western Hemisphere Warm Pool. J. Clim., 18:2662-2681. doi:10.1175/JCLI3427.1

Fairbanks, R.G., Sverdlove, M., Free, R., Wiebe, P.H., and Bé, A.W.H., 1982. Vertical distribution and isotopic fractionation of living planktonic foraminifera from the Panama Basin. Nature (London, U. K.), 298:841-844. doi:10.1038/298841a0

Fairbanks, R.G., and Wiebe, P.H., 1980. Foraminifera and chlorophyll maximum: vertical distribution, seasonal succession, and paleoceanographic significance. Science, 209:1524-1526.

Fairbanks, R.G., Wiebe, P.H., and Bé, A.W.H., 1980. Vertical distribution and isotopic composition of living planktonic foraminifera in the western North Atlantic. Science, 207:61-63.

Farrell, J.W., Raffi, I., Janecek, T.C., Murray, D.W., Levitan, M., Dadey, K.A., Emeis, K.-C., Lyle, M., Flores, J.-A., and Hovan, S., 1995. Late Neogene sedimentation patterns in the eastern equatorial Pacific Ocean. In Pisias, N.G., Mayer, L.A., Janecek, T.R., Palmer-Julson, A., and van Andel, T.H. (Eds.), Proc. ODP, Sci. Results, 138: College Station, TX (Ocean Drilling Program), 717-756.

Faul, K.L., Ravelo, A.C., and Delaney, M.L., 2000. Changes in upwelling, productivity, and photic zone depth in the eastern equatorial Pacific Ocean using plantonic foraminiferal stable isotopes and abundances. J. Foraminiferal Res., 30:110-125. doi:10.2113/0300110

Ganssen, G., and Sarnthein, M., 1983. Stable-isotope composition of foraminifers: the surface and bottom water record of coastal upwelling. In Suess, E., and Thiede, J. (Eds.), Coastal Upwelling: Its Sediment Record. New York (Plenum Press), 10A:99121.

Godfrey, J.S., 1996. The effect of the Indonesian throughflow on ocean circulation and heat exchange with the atmosphere: a review. J. Geophys. Res., 101:1221712237. doi:10.1029/95JC03860

Groeneveld, J., 2005. Effect of the Pliocene closure of the Panamanian Gateway on Caribbean and east Pacific sea surface temperatures and salinities by applying combined $\mathrm{Mg} / \mathrm{Ca}$ and $\delta^{18} \mathrm{O}$ measurements (5.6-2.2 Ma) [Ph.D. dissert.]. Univ. Kiel, Germany. Available from World Wide Web: <http://e-diss.uni-kiel.de/diss_1516/>.

Hamilton, W.B., 1979. Tectonics of the Indonesian Region. Geol. Surv. Prof. Pap. U.S., 1078.

Haug, G.H., and Tiedemann, R., 1998. Effect of the formation of the Isthmus of Panama on Atlantic Ocean thermohaline circulation. Nature (London, U. K.), 393:673676. doi:10.1038/31447

Haug, G.H., Tiedemann, R., Zahn, R., and Ravelo, A.C., 2001. Role of Panama uplift on oceanic freshwater balance. Geology, 29:207-210. doi:10.1130/00917613(2001)029<0207:ROPUOO >2.0.CO;2

Hirst, A.C., and Godfrey, J.S., 1993. The role of Indonesian throughflow in a global ocean GCM. J. Phys. Oceanogr., 23:1057-1086. doi:10.1175/15200485(1993)023<1057:TROITI>2.0.CO;2

Hovan, S.A., 1995. Late Cenozoic atmospheric circulation intensity and climatic history recorded by eolian deposition in the eastern equatorial Pacific Ocean, Leg 138. In Pisias, N.G., Mayer, L.A., Janecek, T.R., Palmer-Julson, A., and van Andel, T.H. (Eds.), Proc. ODP, Sci. Results, 138: College Station, TX (Ocean Drilling Program), 615-625.

Huang, R.X., Cane, M.A., Naik, N., and Goodman, P., 2000. Global adjustment of the thermocline in response to deepwater formation. Geophys. Res. Lett., 27(6):759762. doi:10.1029/1999GL002365

Ito, G., and Clift, P.D., 1998. Subsidence and growth of Pacific Cretaceous plateaus. Earth Planet. Sci. Lett., 161(1-4):85-100. doi:10.1016/S0012-821X(98)00139-3 
Jansen, E., and Sjøholm, J., 1991. Reconstruction of glaciation over the past 6 Myr from ice-borne deposits in the Norwegian Sea. Nature (London, U. K.), 349:600-603.

Jousaumme, S., Sadourny, R., and Vignal, C., 1986. Origin of precipitating water in a numerical simulation of the July climate. Ocean-Air Interact., 1:43-56.

Kameo, K., and Sato, T., 2000. Biogeography of Neogene calcareous nannofossils in the Caribbean and the eastern equatorial Pacific: floral response to the emergence of the Isthmus of Panama. Mar. Micropaleontol., 39:201-218. doi:10.1016/S03778398(00)00021-9

Keigwin, L., 1982. Isotopic paleoceanography of the Caribbean and east Pacific: role of Panama uplift in late Neogene time. Science, 217:350-353.

Kennett, J.P., Keller, G., and Srinivasan, M.S., 1985. Miocene planktonic foraminiferal biogeography and paleoceanographic development of the Indo-Pacific region. In Kennett, J.P. (Ed.), The Miocene Ocean: Paleoceanography and Biogeography. Mem.Geol. Soc. Am., 163:197-236.

Kennett, J.P., and Srinivasan, M.S., 1983. Neogene Planktonic Foraminifera: A Phylogenetic Atlas: Stroudsburg, PA (Hutchinson Ross).

Kleiven, H.F., Jansen, E., Fronval, T., and Smith, T.M., 2002. Intensification of Northern Hemisphere glaciations in the circum Atlantic region (3.5-2.4 Ma)-ice-rafted detritus. Palaeogeogr., Palaeoclimatol., Palaeoecol., 184:213-223. doi:10.1016/ S0031-0182(01)00407-2

Kroopnick, P., 1974. The dissolved $\mathrm{O}_{2}-\mathrm{CO}_{2^{-13}} \mathrm{C}$ system in the eastern equatorial Pacific. Deep-Sea Res., Part A, 21:169-174. doi:10.1016/0011-7471(74)90059-X

Laskar, J., Joutel, F., and Boudin, F., 1993. Orbital, precessional, and insolation quantities for the Earth from $-20 \mathrm{Myr}$ to $+10 \mathrm{Myr}$. Astron. Astrophys., 270:522-533.

Leetma, A., 1982. Observations of near-equatorial flows in the eastern Pacific. J. Mar. Res., 40:357-370.

Lisiecki, L.E., and Raymo, M.E., 2005. A Pliocene-Pleistocene stack of 57 globally distributed benthic $\delta^{18} \mathrm{O}$ records. Paleoceanography, 20. doi:10.1029/2004PA001071

Lohmann, G.P., 1995. A model of variation in the chemistry of planktonic foraminifers due to secondary calcification and selective dissolution. Paleoceanography, 10:445-458. doi:10.1029/95PA00059

Loubere, P., 2000. Marine control of biological production in the eastern equatorial Pacific Ocean. Nature (London, U. K.), 406:497-500. doi:10.1038/35020041

Loubere, P., 2001. Nutrient and oceanographic changes in the eastern equatorial Pacific from the last full glacial to the present. Global Planet. Change, 29:77-98. doi:10.1016/S0921-8181(00)00085-0

Lundelius, E.L., Jr., 1987. The North American Quaternary sequence. In Woodburne, M.O. (Ed.), Cenozoic Mammals of North America: Berkeley (Univ. California Press), 211-235.

Maier-Reimer, E., Mikolajewicz, U., and Crowley, T., 1990. Ocean general circulation model sensitivity experiment with an open Central American Isthmus. Paleoceanography, 5:349-366.

McKenna, V.S., Farrell, J.W., Murray, D.W., and Clemens, S.C., 1995. The foraminifer record at Site 847: paleoceanographic response to late Pleistocene climate variability. In Pisias, N.G., Mayer, L.A., Janecek, T.R., Palmer-Julson, A., and van Andel, T.H. (Eds.), Proc. ODP, Sci. Results, 138: College Station, TX (Ocean Drilling Program), 695-714.

McPhaden, M.J., 1986. The equatorial under current: 100 years of discovery. Eos, Trans. Am. Geophys. Union, 67(40):762-764.

Mielke, K.M., 2001. Reconstructing surface carbonate chemistry and temperature in paleoceans: geochemical results from laboratory experiments and the fossil record [M.S. thesis]. Univ. of California, Davis.

Mikolajewicz, U., and Crowley, T.J., 1997. Response of a coupled ocean/energy balance model to restricted flow through the Central American isthmus. Paleoceanography, 12:429-441. doi:10.1029/96PA03542 
Mix, A.C., Pisias, N.G., Rugh, W., Wilson, J., Morey, A., and Hagelberg, T.K., 1995. Benthic foraminifer stable isotope record from Site 849 (0-5 Ma): local and global climate changes. In Pisias, N.G., Mayer, L.A., Janecek, T.R., Palmer-Julson, A., and van Andel, T.H. (Eds.), Proc. ODP, Sci. Results, 138: College Station, TX (Ocean Drilling Program), 371-412.

Mix, A.C., Tiedemann, R., Blum, P., et al., 2003. Proc. ODP, Init. Repts., 202: College Station, TX (Ocean Drilling Program). doi:10.2973/odp.proc.ir.202.2003

Molnar, P., and Cane, M.A., 2002. El Niño's tropical climate and teleconnections as a blueprint for pre-Ice Age climates. Paleoceanography, 17(2). doi:10.1029/ 2001PA000663

Mulitza, S., Arz, H., Kemle-von Mücke, S., Moos, C., Niebler, H.-S., Pätzold, J., and Segl, M., 1999. The south Atlantic carbon isotope record of planktic foraminifera. In Fischer, G., and Wefer, G. (Eds.), Use of Proxies in Paleoceanography: Examples from the South Atlantic: New York (Springer-Verlag), 427-445.

Niebler, H.-S., Hubberten, H.-W., and Gersonde, R., 1999. Oxygen isotope values of planktic foraminifera: a tool for the reconstruction of surface water stratification. In Fischer, G., and Wefer, G. (Eds.), Use of Proxies in Paleoceanography: New York (Springer-Verlag), 165-189.

Ninnemann, U.S., and Charles, C.D., 1997. Regional differences in Quaternary subantarctic nutrient cycling: link to intermediate and deep water ventilation. Paleoceanography, 12:560-567. doi:10.1029/97PA01032

Nisancioglu, K.H., Raymo, M.E., and Stone, P.H., 2003. Reorganization of Miocene deep water circulation in response to the shoaling of the Central American Seaway. Paleoceanography, 18(1). doi:10.1029/2002PA000767

Norris, R.D., 1998. Miocene-Pliocene surface-water hydrography of the eastern equatorial Atlantic. In Mascle, J., Lohmann, G.P., and Moullade, M. (Eds.), Proc. ODP, Sci. Results, 159: College Station, TX (Ocean Drilling Program), 539-555. [PDF]

Nürnberg, D., Müller, A., and Schneider, R.R., 2000. Paleo-sea surface temperature calculations in the equatorial east Atlantic from $\mathrm{Mg} / \mathrm{Ca}$ ratios in planktic foraminifers: a comparison to sea surface temperature estimates from $\mathrm{U}_{37} \mathrm{~K}^{\prime}$, oxygen isotopes, and foraminiferal transfer function. Paleoceanography, 15:124-134. doi:10.1029/1999PA000370

Oppo, D.W., and Fairbanks, R.G., 1989. Carbon isotope composition of tropical surface water during the past 22,000 years. Paleoceanography, 4:333-351.

Ortiz, J., Mix, A., Hostetler, S., and Kashgarian, M., 1997. The California current of the last glacial maximum: reconstruction at $42^{\circ} \mathrm{N}$ based on multiple proxies. Paleoceanography, 12:191-205. doi:10.1029/96PA03165

Ortiz, J.D., Mix, A.C., and Collier, R.W., 1995. Environmental control of living symbiotic and asymbiotic foraminifera of the California current. Paleoceanography, 10:987-1010. doi:10.1029/95PA02088

Ortiz, J.D., Mix, A.C., Rugh, W., Watkins, J.M., and Collier, R.W., 1996. Deep-dwelling planktonic foraminifera of the northeastern Pacific Ocean reveal environmental control of oxygen and carbon isotopic disequilibria. Geochim. Cosmochim. Acta, 60:4509-4523. doi:10.1016/S0016-7037(96)00256-6

Parker, F.L., 1967. Late Tertiary biostratigraphy (planktonic foraminifera) of tropical Indo-Pacific deep-sea cores. Bull. Am. Paleontol., 52:111-208.

Parsons, B., and Sclater, J.G., 1977. An analysis of the variation of ocean floor bathymetry and heat flow with age. J. Geophys. Res., 82:803-827.

Philander, S.G.H., 1973. Equatorial undercurrent: measurements and theories. Rev. Geophys. Space Phys., 11:513-570.

Pisias, N.G., Mayer, L.A., and Mix, A.C., 1995. Paleoceanography of the eastern equatorial Pacific during the Neogene: synthesis of Leg 138 drilling results. In Pisias, N.G., Mayer, L.A., Janecek, T.R., Palmer-Julson, A., and van Andel, T.H. (Eds.), Proc. ODP, Sci. Results, 138: College Station, TX (Ocean Drilling Program), 5-21. 
Prange, M., and Schulz, M., 2004. A coastal upwelling seasaw in the Atlantic Ocean as a result of the closure of the Central American Seaway. J. Geophys. Res., 31: doi:10.1029/2004GL020073

Ravelo, A.C., and Andreasen, D.H., 1999. Using planktonic foraminifera as monitors of the tropical surface ocean. In Abrantes, F., and Mix, A. (Eds.), Reconstructing Ocean History $-A$ Window Into the Future: New York (Plenum Press), 217-244.

Ravelo, A.C., Andreasen, D.H., Lyle, M., Lyle, A.O., and Wara, M.W., 2004. Regional climate shifts caused by gradual global cooling in the Pliocene epoch. Nature (London, U. K.), 429:263-267. doi:10.1038/nature02567

Ravelo, A.C., and Fairbanks, R.G., 1992. Oxygen isotopic composition of multiple species of planktonic foraminifera: recorders of the modern photic zone temperature gradient. Paleoceanography, 7:815-831.

Ravelo, A.C., and Fairbanks, R.G., 1995. Carbon isotopic fractionation in multiple species of planktonic foraminifera from core-tops in the tropical Atlantic. J. Foraminiferal Res., 25:53-74.

Ravelo, A.C., Fairbanks, R.G., and Philander, G., 1990. Reconstructing tropical Atlantic hydrography using planktonic foraminifera and an ocean model. Paleoceanography, 5:409-431.

Ravelo, A.C., and Shackleton, N.J., 1995. Evidence for surface-water circulation changes at Site 851 in the eastern tropical Pacific. In Pisias, N.G., Mayer, L.A., Janecek, T.R., Palmer-Julson, A., and van Andel, T.H. (Eds.), Proc. ODP, Sci. Results, 138: College Station, TX (Ocean Drilling Program), 503-514.

Raymo, M.E., Grant, B., Horowitz, M., and Rau, G.H., 1996. Mid-Pliocene warmth: stronger greenhouse and stronger conveyor. Mar. Micropaleontol., 27:313-326. doi:10.1016/0377-8398(95)00048-8

Sautter, L.R., and Thunell, R.C., 1991. Planktonic foraminiferal response to upwelling and seasonal hydrographic conditions: sediment trap results from San Pedro Basin, Southern California bight. J. Foraminiferal Res., 21:347-363.

Schrag, D.P., Hampt, G., and Murray, D.W., 1996. Pore fluid constraints on the temperature and oxygen isotopic composition of the glacial ocean. Science, 272:19301932.

Shackleton, N.J., 1974. Attainment of isotopic equilibrium between ocean water and the benthonic foraminifera genus Uvigerina: isotopic changes in the ocean during the last glacial. Les Meth. Quant. d'etude Var. Clim. au Cours du Pleist., Coll. Int. CNRS., 219:203-209.

Shackleton, N.J., 2000. The 100,000-year ice-age cycle identified and found to lag temperature, carbon dioxide, and orbital eccentricity. Science, 289:1897-1902. doi:10.1126/science.289.5486.1897

Shackleton, N.J., Hall, M.A., and Pate, D., 1995. Pliocene stable isotope stratigraphy of Site 846. In Pisias, N.G., Mayer, L.A., Janecek, T.R., Palmer-Julson, A., and van Andel, T.H. (Eds.), Proc. ODP, Sci. Results, 138: College Station, TX (Ocean Drilling Program), 337-355.

Spero, H.J., and Lea, D.W., 2002. The cause of carbon isotope minimum events on glacial terminations. Science, 296:522-525. doi:10.1126/science.1069401

Spero, H.J., Mielke, K.M., Kalve, E.M., Lea, D.W., and Pak, D.K., 2003. Multispecies approach to reconstructing eastern Pacific thermocline hydrography during the past 360 kyr. Paleoceanography, 18(1):1022. doi:10.1029/2002PA000814

Srinivasan, M.S., and Kennett, J.P., 1976. Evolution and phenotypic variation in the late Cenozoic Neogloboquadrina dutertrei plexus. In Takayanagi, Y., and Saito, T. (Eds.), Progress in Micropaleontology: Selected Papers in Honor of Prof. Kiyoshi Asano: New York (Micropaleontol. Press), 329-355.

Steph, S., Tiedemann, R., Prange, M., Groeneveld, J., Nürnberg, D., Reuning, L., Schulz, M., and Haug, G., in press. Changes in Caribbean surface hydrography during the Pliocene shoaling of the Central American seaway. Paleoceanography. 
Strub, P.T., Mesias, J.M., Montecino, V., Rutllant, J., and Salinas, S., 1998. Coastal ocean circulation off western South America. In Robinson, A.R., and Brink, K.H. (Eds.), The Sea (Vol. 11): Coastal Oceans: New York (Wiley), 273-313.

Thunell, R.C., and Sautter, L.R., 1992. Planktonic foraminiferal faunal and stable isotopic indices of upwelling: a sediment trap study in the San Pedro Basin, Southern California bight. In Summerhayes, C.P., Prell, W.L., and Emeis, K.C. (Eds.), Upwelling Systems: Evolution Since the Early Miocene: 77-91.

Tiedemann, R., and Franz, S.O., 1997. Deep-water circulation, chemistry, and terrigenous sediment supply in the equatorial Atlantic during the Pliocene, 3.3-2.6 Ma and 5-4.5 Ma. In Shackleton, N.J., Curry, W.B., Richter, C., and Bralower, T.J. (Eds.), Proc. ODP, Sci. Results, 154: College Station, TX (Ocean Drilling Program), 299-318. [PDF]

Tiedemann, R., Sarnthein, M., and Shackleton, N.J., 1994. Astronomic timescale for the Pliocene Atlantic $\delta^{18} \mathrm{O}$ and dust flux records of Ocean Drilling Program Site 659. Paleoceanography, 9:619-638.

Toggweiler, J.R., Dixon, K., and Broecker, W.S., 1991. The Peru upwelling and the ventilation of the south Pacific thermocline. J. Geophys. Res., 96:20467-20497.

Wara, M.W., Ravelo, A.C., and Delaney, M.L., 2005. Permanent El Niño-like conditions during the Pliocene warm period. Science, 309:758-761. doi:10.1126/science.1112596

Watkins, J.M., and Mix, A.C., 1998. Testing the effects of tropical temperature, productivity, and mixed-layer depth on foraminiferal transfer functions. Paleoceanography, 13:96-105. doi:10.1029/97PA02904

Watkins, J.M., Mix, A.C., and Wilson, J., 1998. Living planktic foraminifera in the central tropical Pacific Ocean: articulating the equatorial "cold tongue" during La Niña, 1992. Mar. Micropaleontol., 33:157-174. doi:10.1016/S0377-8398(97)00036-4

Webb, S.D., 1985. Late Cenozoic mammal dispersals between the Americas. In Stehli, F.G., and Webb, S.D. (Eds.), The Great American Biotic Interchange: New York (Plenum Press), 357-386.

Whitman, J.M., and Berger, W.H., 1993. Pliocene-Pleistocene carbon isotope record, Site 856, Ontong Java Plateau. In Berger, W.H., Kroenke, L.W., Mayer, L.A., et al., Proc. ODP, Sci. Results, 130: College Station, TX (Ocean Drilling Program), 333-348.

Wyrtki, K., 1966. Oceanography of the eastern equatorial Pacific Ocean. Oceanogr. Mar. Biol. Ann. Rev., 4:33-68.

Wyrtki, K., 1981. An estimate of equatorial upwelling in the Pacific. J. Phys. Oceanogr., 11:1205-1214. doi:10.1175/1520-0485(1981)011<AEOEUI>2.O.CO;2 
S. STEPH ET AL.

Tropical East Pacific Upper OCEAN STRATIfication

\section{APPENDIX}

Oxygen and carbon isotopes of planktonic foraminifers from Site 1241 are shown in Table AT1.

$\mathrm{Mg} / \mathrm{Ca}$ ratios of deep-dwelling planktonic foraminifers from Site

$\overline{\text { AT1. Oxygen and carbon isotopes }}$ of planktonic foraminifers, p. 49. 1241 are shown in Table AT2.

AT2. Mg/Ca ratios of deep-dwelling planktonic foraminifers, p. 50. 
S. STEPH ET AL.

Tropical East Pacific UpPer OCEAN Stratification

Figure F1. Map of the TEP showing major surface currents. The locations of ODP Sites 851 and 1241 and their plate tectonic backtracks (in 1-m.y. steps) are indicated. Solid dots $=$ modern position, open dots = paleopositions of these sites at $6 \mathrm{Ma}$. NEC $=$ North Equatorial Current, NECC $=$ North Equatorial Counter Current, EUC = Equatorial Under Current, $\mathrm{SEC}=$ South Equatorial Current, $\mathrm{PCC}=$ Peru-Chile Current.

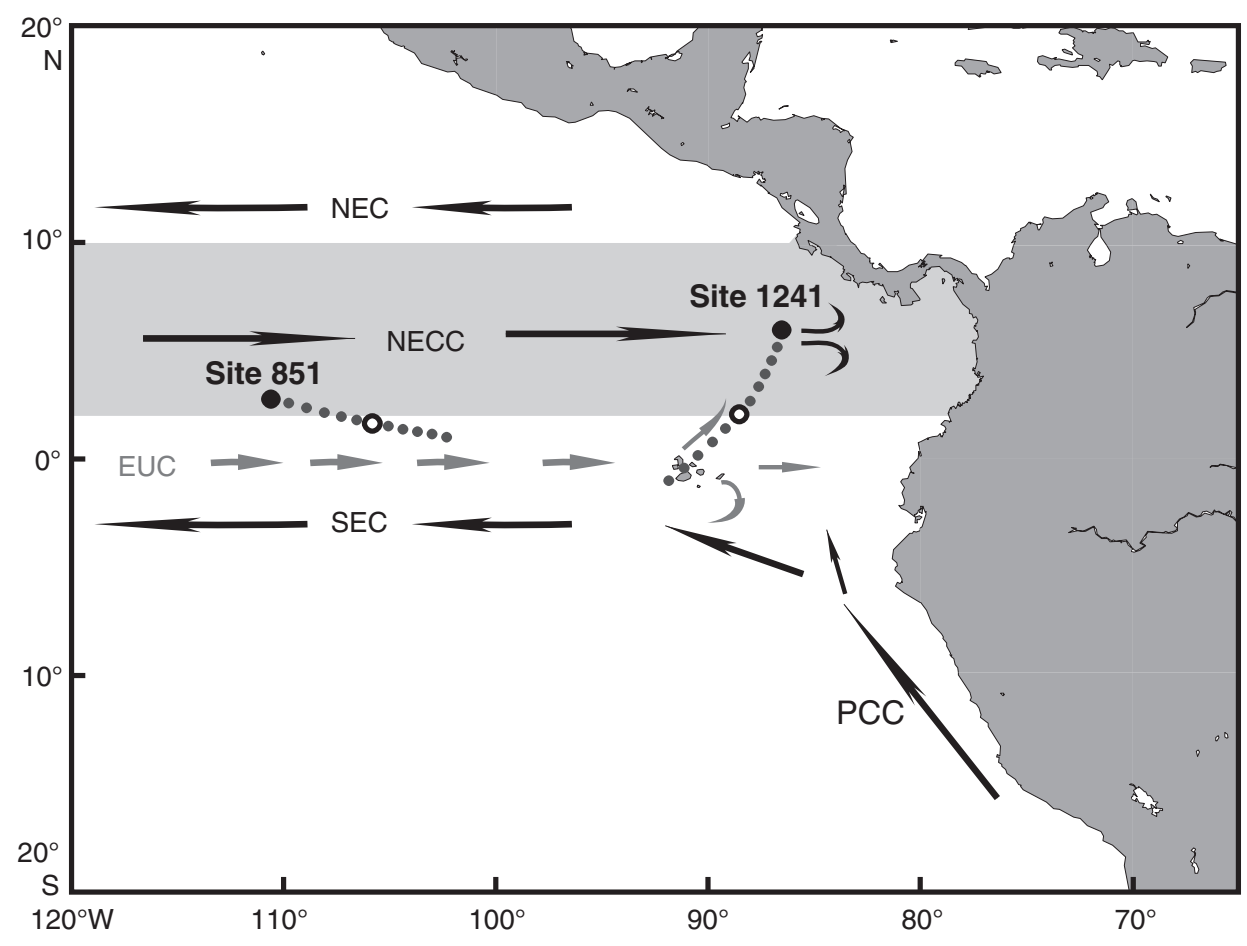


S. STEPH ET AL.

Tropical East Pacific Upper Ocean Stratification

Figure F2. Modern annual-average properties of the upper ocean at paleolocations of Site 1241 for the last 11 m.y., based on plate tectonic backtracking (Mix, Tiedemann, Blum, et al., 2003) and the assumption of no temporal changes in regional oceanographic properties. Atlas data on physical and chemical properties are from WOA01 (Conkright et al., 2002). Symbols are average values extracted from the nearest $1^{\circ}$ latitude/ longitude box in the atlas. If the paleolocation occurred at the boundary between neighboring boxes, we calculated the mean values from both boxes. Lines indicate smoothed trends of each property along the backtrack path. Shaded area marks the time interval relevant for this study.

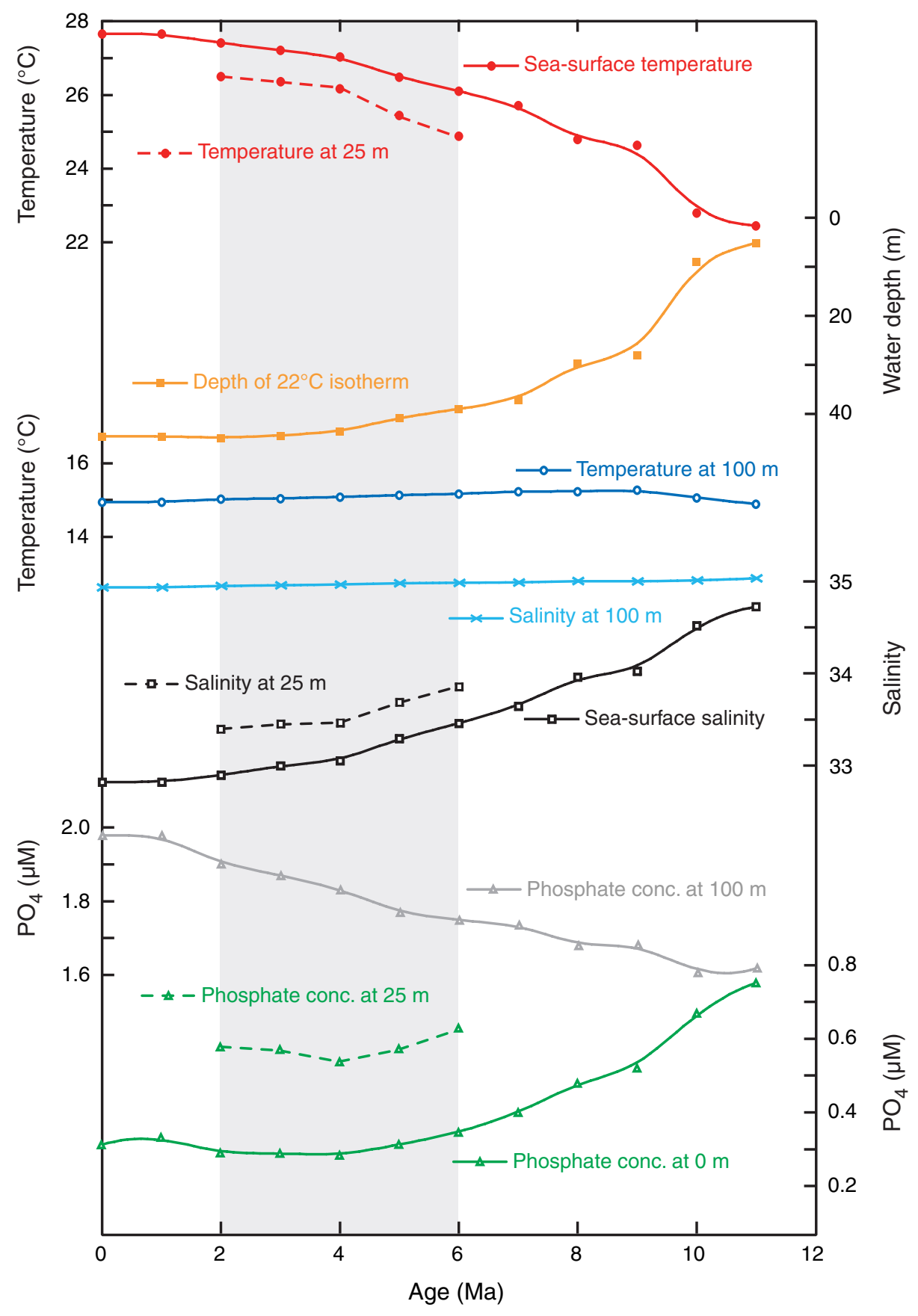


S. STEPH ET AL.

Tropical east Pacific Upper Ocean Stratification

Figure F3. Modern annual-average properties of the upper water column for the TEP and assumed habitat depths for the planktonic foraminiferal species used in this study. Atlas data on physical and chemical properties are from WOA01 (Conkright et al., 2002), squares 7008 and $7009\left(10^{\circ} \mathrm{N} / 100^{\circ} \mathrm{W}-0^{\circ} \mathrm{N}, 80^{\circ} \mathrm{W}\right)$. Data from the Caribbean were excluded. Thick lines indicate mean values. Shaded areas show the range of standard deviation. Red $=$ temperature, blue $=$ salinity, green $=$ chlorophyll a concentration . Black line $=$ percentage of irradiance, data taken from Enfield and Lee (2005); the 0.1\% irradiance level is defined as the base of the euphotic zone. The gray area indicates the thermocline as zone with the highest vertical temperature gradient. Bars to the right show the range of preferred habitat depths for Globigerinoides sacculifer, Globorotalia menardii (Globorotalia limbata?), Neogloboquadrina dutertrei, and Globorotalia tumida.

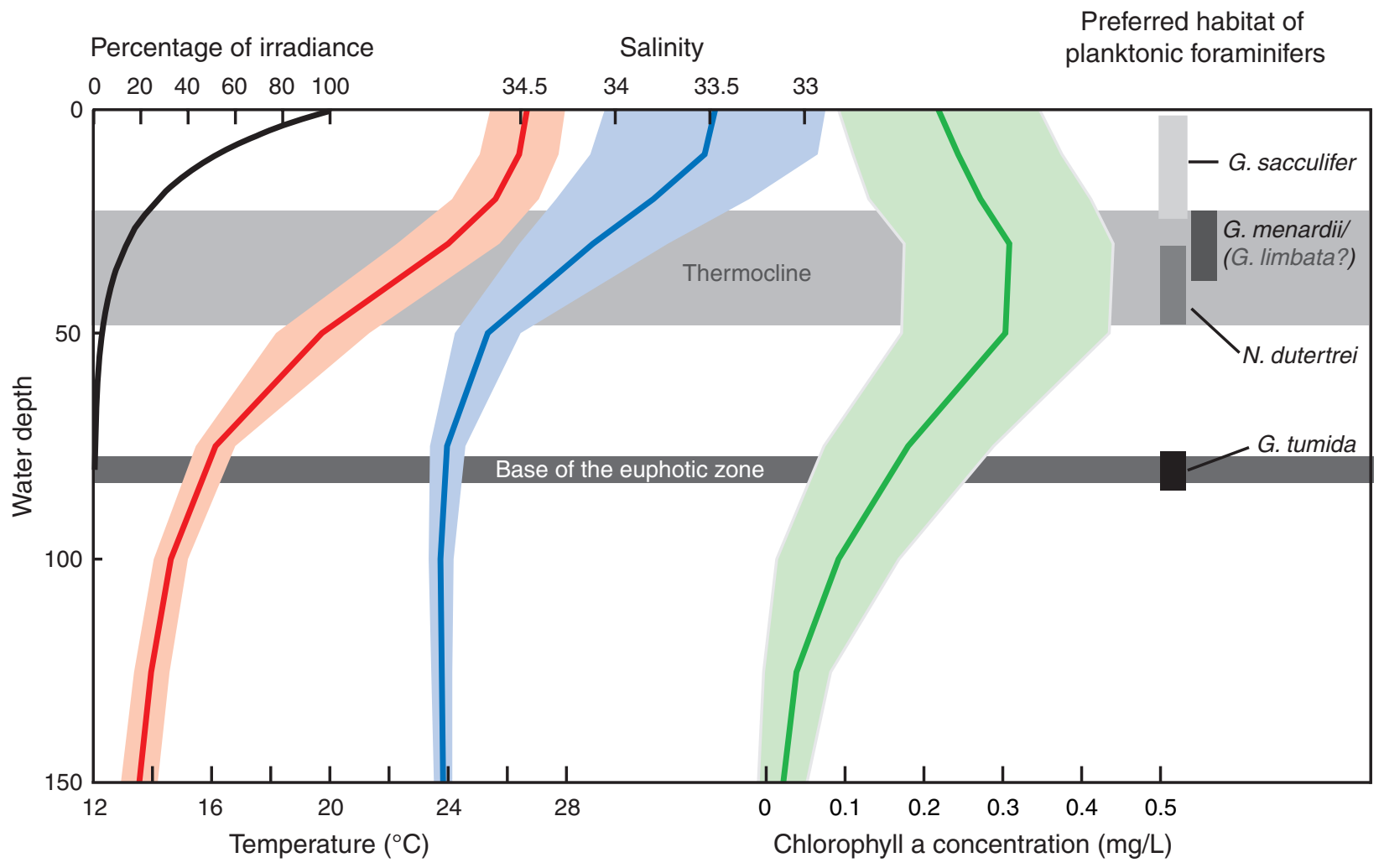


Figure F4. SEM pictures of the planktonic foraminiferal taxa used in this study. A. Globigerinoides sacculifer (without saclike final chamber) from Sample 202-1241A-9H-6, 0 cm. B. Globorotalia menardii from Sample 202-1241B-12H-6, 60 cm. C. Globorotalia menardii from Sample 202-1241C-8H-5, 130 cm. D. Globorotalia limbata (dextral) from Sample 202-1241C-8H-5, $130 \mathrm{~cm}$. E. Globorotalia limbata (dextral) from Sample 202$1241 \mathrm{C}-8 \mathrm{H}-5,130 \mathrm{~cm}$. F. Neogloboquadrina dutertrei (dextral) from Sample 202-1241C-8H-5, $130 \mathrm{~cm}$. G. Neogloboquadrina dutertrei (dextral) from Sample 202-1241A-9H-6, $0 \mathrm{~cm}$. H. Globorotalia tumida from Sample 202-1241A-14H-6, 10 cm. H. Globorotalia tumida from Sample 202-1241C-8H-5, 130 cm.

Globigerinoides sacculifer

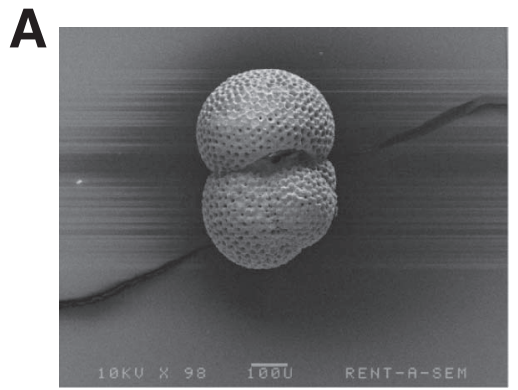

B

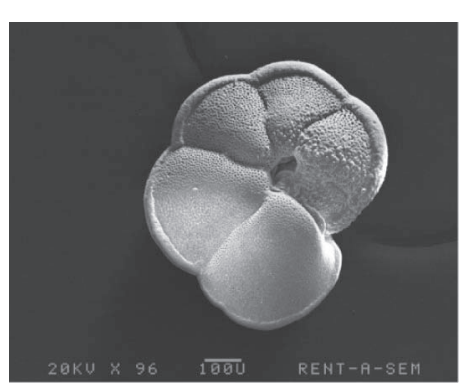

Globorotalia menardii (dextral)

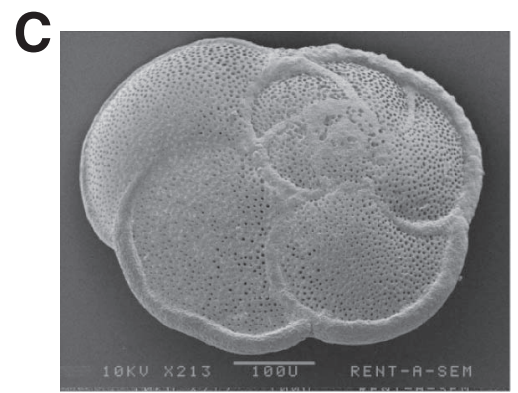

Globorotalia limbata (dextral)
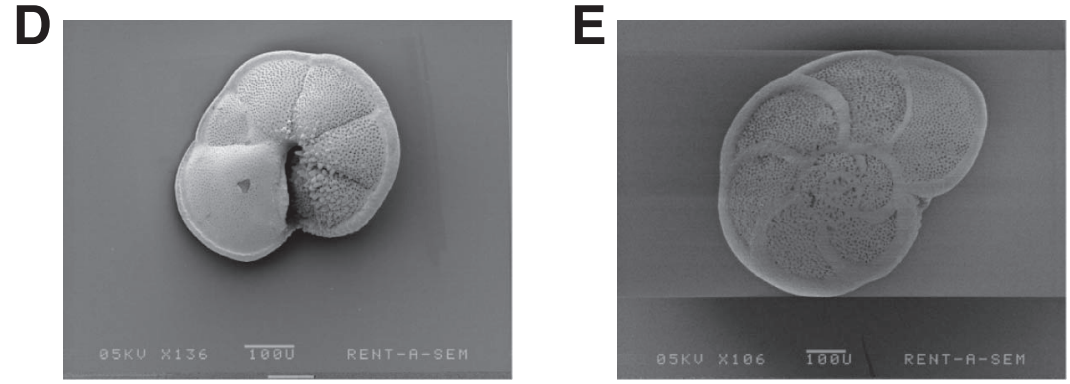

Neogloboquadrina dutertrei (dextral)

$\mathbf{F}$

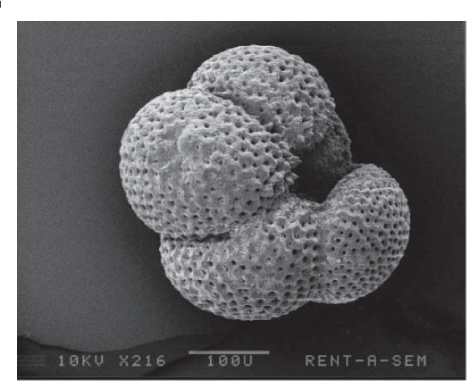

G

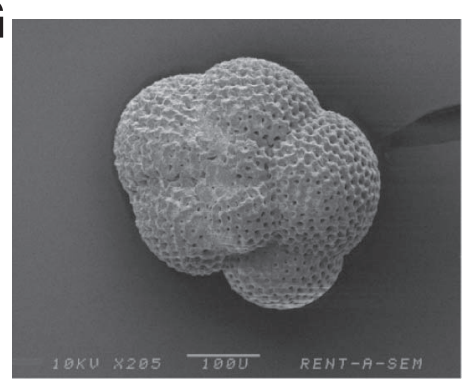

Globorotalia tumida
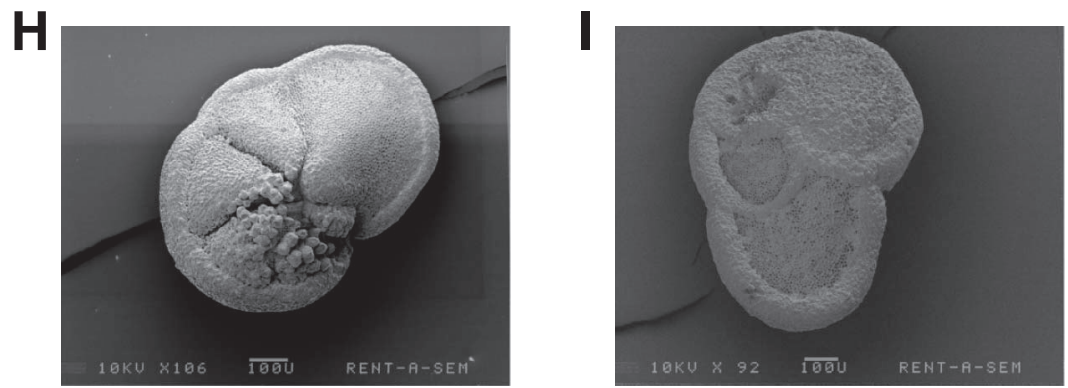
S. STEPH ET AL.

Tropical East Pacific UpPer OCEAN Stratification

Figure F5. Multispecies (A) planktonic $\delta^{18} \mathrm{O}$ records compared to the (B) benthic $\delta^{18} \mathrm{O}$ record of Site 1241 (Tiedemann et al., this volume). Thin lines show measured isotope data, thick lines show smoothed isotope records. A. Gray line = Globigerinoides sacculifer, blue line = Globorotalia limbata $($ dextral $)$, red line $=$ Neogloboquadrina dutertrei (dextral), black line = Globorotalia tumida. B. Marine isotope stages (MIS) Si6 ( 4.9 Ma), M2 ( 3.3 Ma), G6 ( 2.7 Ma), and 96, 98, $100(\sim 2.5 \mathrm{Ma})$ are indicated. NHG = Northern Hemisphere glaciation.

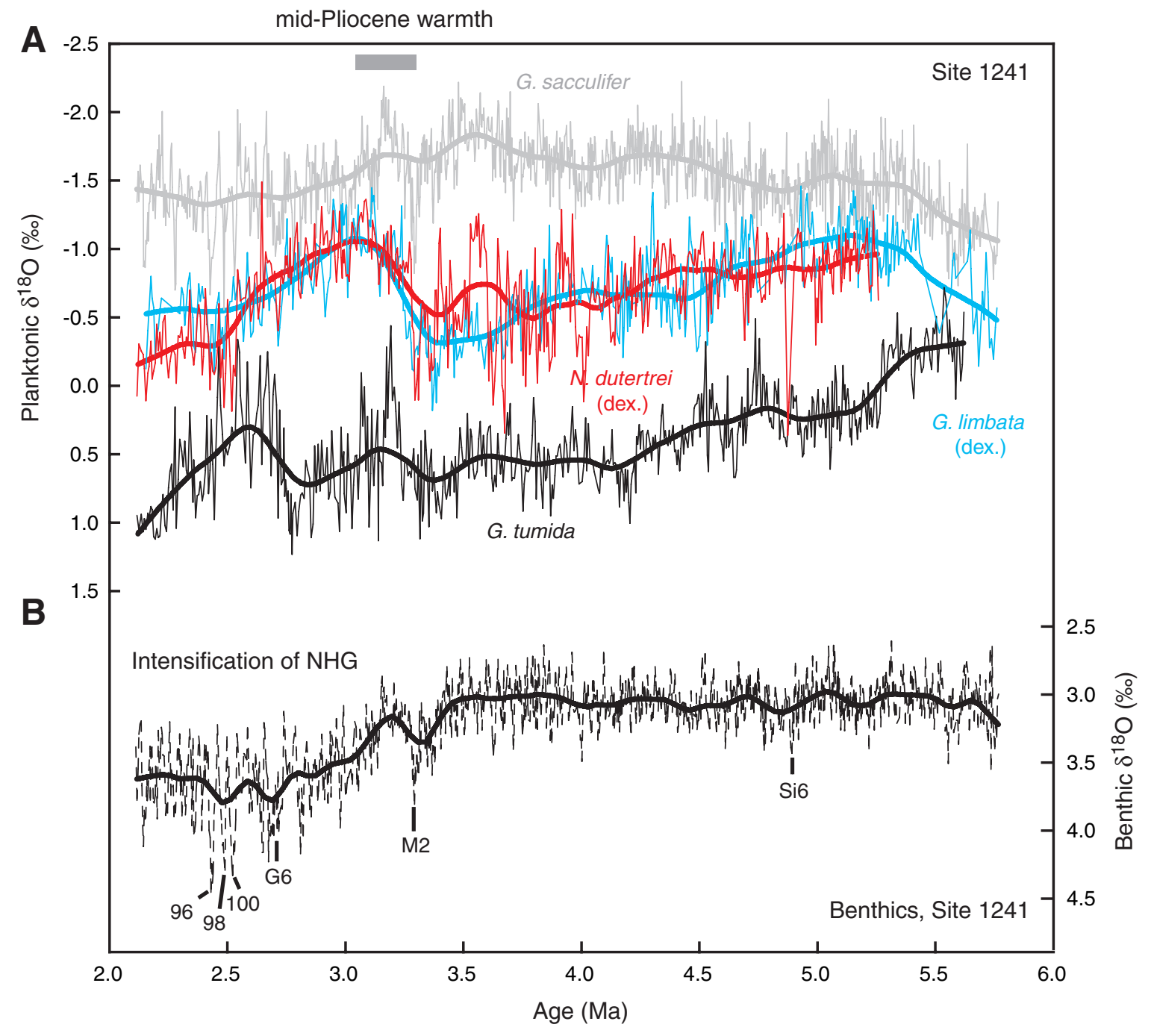


S. STEPH ET AL.

Tropical East Pacific UpPer OCEAN Stratification

Figure F6. $\delta^{18} \mathrm{O}$ values (gray), $\delta^{18} \mathrm{O}_{\text {seawater }}$ (black), and $\mathrm{Mg} / \mathrm{Ca}$ temperatures (red) for (A) Globigerinoides sacculifer $(\mathrm{Mg} / \mathrm{Ca}$ data are presented in Groeneveld et al., this volume), (B) Globorotalia limbata, (C) Neogloboquadrina dutertrei, and (D) Globorotalia tumida at ODP Site 1241. $\mathrm{Mg} / \mathrm{Ca}$ temperatures were calculated using the paleotemperature equation of Anand et al. (2003). $\delta^{18} \mathrm{O}_{\text {seawater }}$ was calculated for each species by combining $\mathrm{Mg} / \mathrm{Ca}$ temperatures and $\delta^{18} \mathrm{O}$ values according to Shackleton (1974).

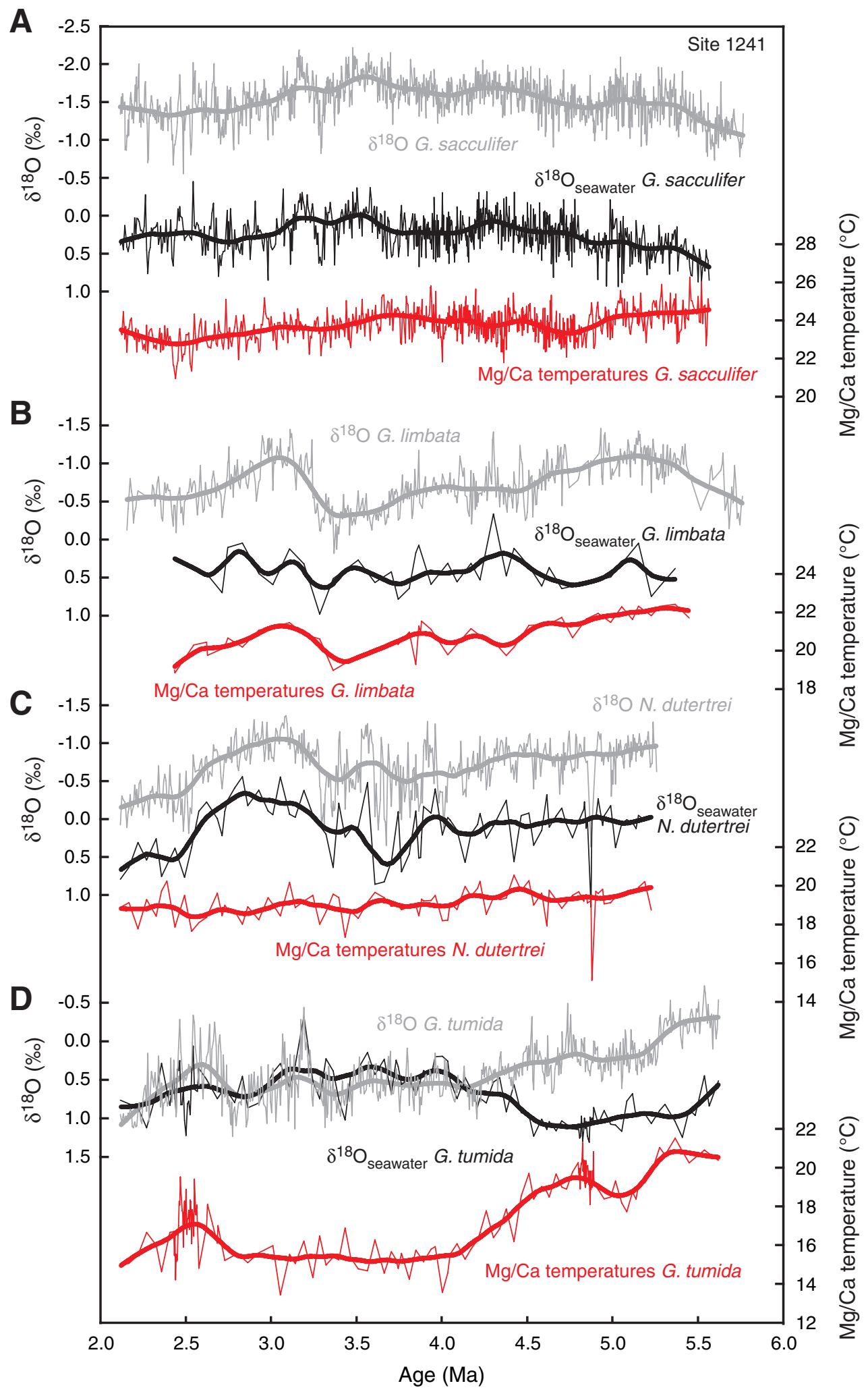


S. STEPH ET AL.

Tropical East Pacific UpPer OCEAN Stratification

Figure F7. $\delta^{18} \mathrm{O}_{\text {seawater }}$ records for (A) Globigerinoides sacculifer, (B) Globorotalia limbata (dextral), (C) Neogloboquadrina dutertrei (dextral), and (D) Globorotalia tumida compared to the LR04 benthic $\delta^{18} \mathrm{O}$ stack (E) (Lisiecki and Raymo, 2005; measure for changes in global ice volume). Marine isotope stages Si6, MG5, M2, G6, and 96, 98, 100 are indicated.

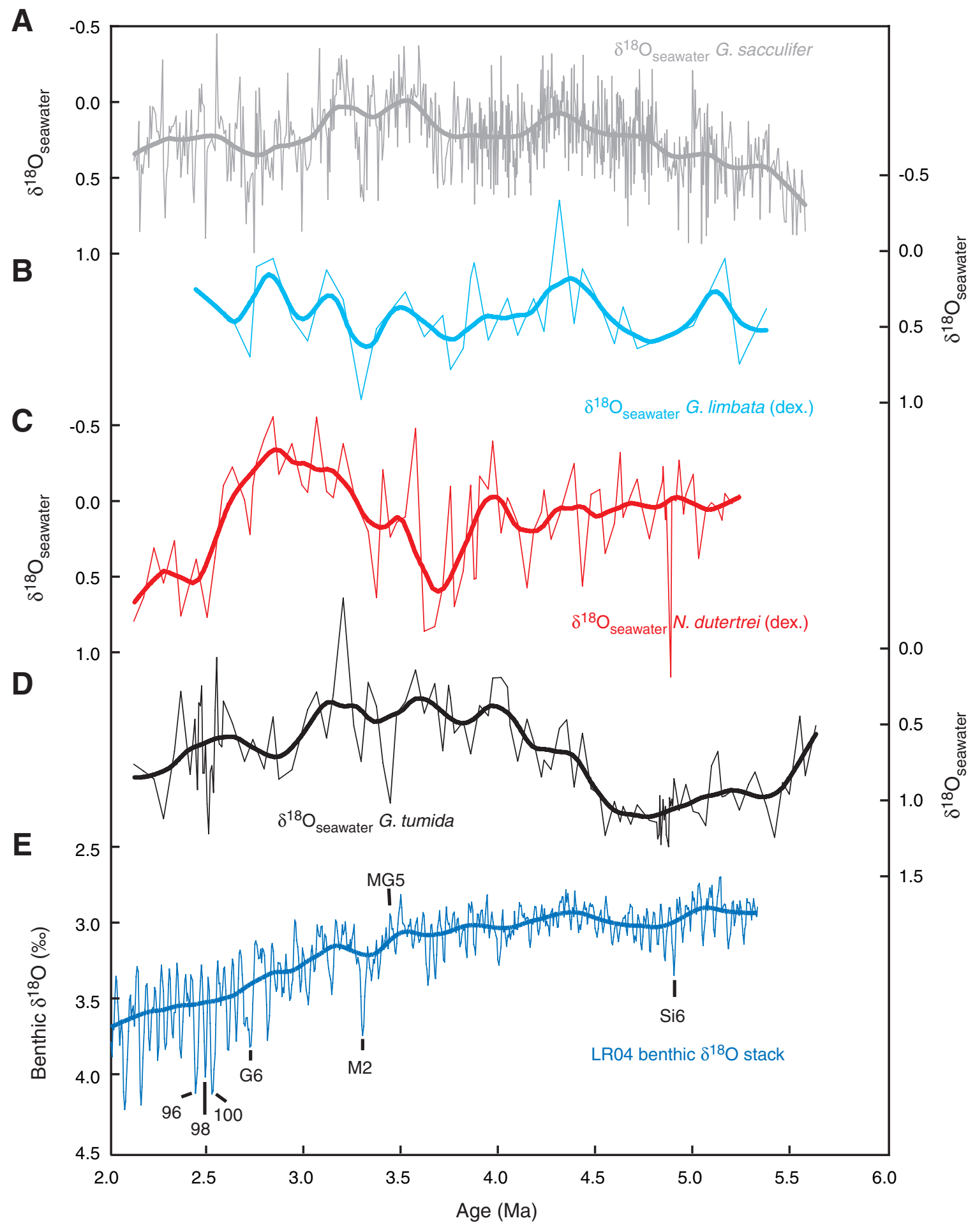


S. STEPH ET AL.

Tropical East Pacific UpPer OCEAN Stratification

Figure F8. A. $\mathrm{Mg} / \mathrm{Ca}$ ratios of planktonic foraminifers with different habitat depths, Site 1241. gray line = Globigerinoides sacculifer, mixed layer (see Groeneveld et al., this volume); blue line = Globorotalia limbata (dextral), upper thermocline; red line = Neogloboquadrina dutertrei (dextral), lower thermocline; black line = Globorotalia tumida, bottom of the photic zone. B. $\mathrm{Mg} / \mathrm{Ca}$ derived water temperatures at the habitat depth of planktonic foraminifers from Site 1241, calculated via the $\mathrm{Mg} / \mathrm{Ca}$ temperature equation of Anand et al. (2003). C. Temperature gradients between different planktonic foraminifers. blue line $=\Delta T$ G. sacculifer-G. limbata (dextral), red line $=\Delta T$ G. sacculifer $-N$. dutertrei (dextral), black line $=\Delta T$ G. sacculifer $-G$. tumida .

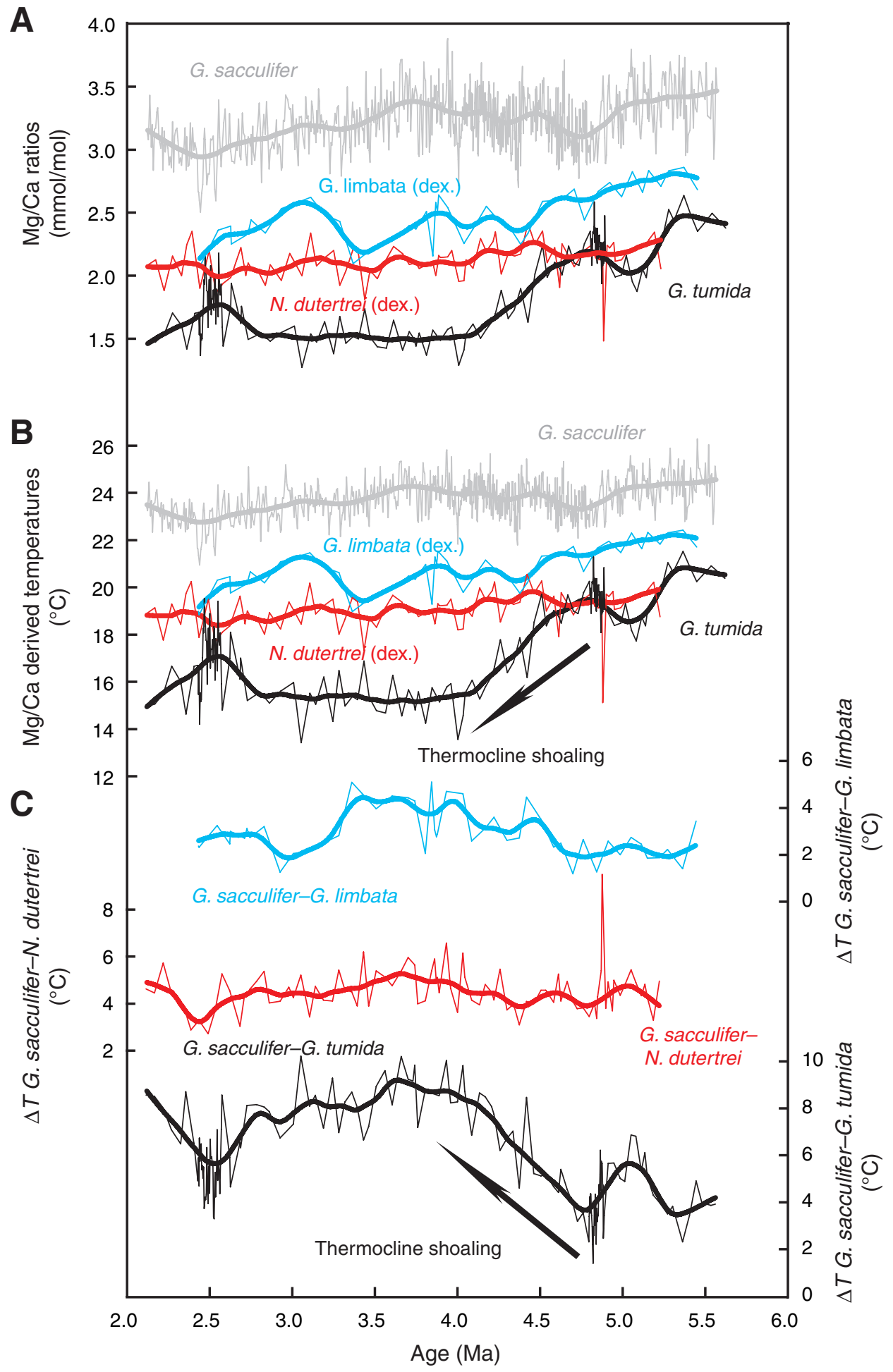


S. STEPH ET AL.

Tropical East Pacific UpPer OCEAN Stratification

Figure F9. A. $\delta^{18} \mathrm{O}_{\text {seawater }}$ at the habitat depth of different planktonic foraminifers, Site 1241. Gray line $=$ Globigerinoides sacculifer, mixed layer; blue line = Globorotalia limbata (dextral), upper thermocline; red line = Neogloboquadrina dutertrei (dextral), lower thermocline; black line = Globorotalia tumida, bottom of the photic zone. B. $\delta^{18} \mathrm{O}_{\text {seawater }}$ gradients between different planktonic foraminifers. Blue line $=\Delta \delta^{18} \mathrm{O}_{\text {seawater }} G$. sacculifer-G. limbata (dextral), red line $=\Delta \delta^{18} \mathrm{O}_{\text {seawater }} G$. sacculifer-N. dutertrei (dextral), black line $=$ $\Delta \delta^{18} \mathrm{O}_{\text {seawater }}$ G. sacculifer-G. tumida.

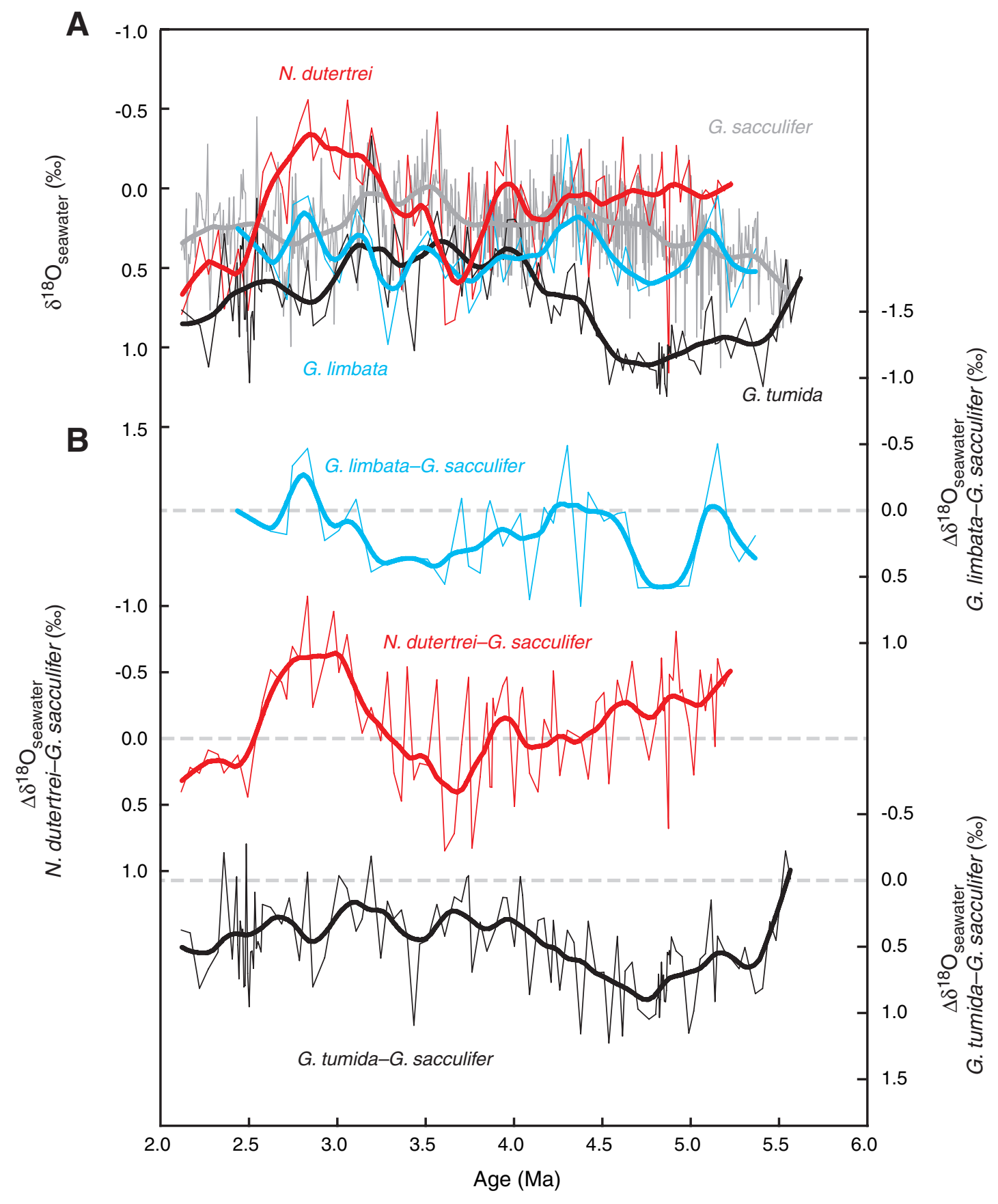


S. STEPH ET AL.

Tropical East Pacific UpPer OCEAN Stratification

Figure F10. A. $\delta^{13} \mathrm{C}$ records of planktonic foraminifers from different habitat depths, Site 1241, compared to the benthic $\delta^{13} \mathrm{C}$ record from Site 1241 (blue dashed line; Tiedemann et al., this volume). Gray line = Globigerinoides sacculifer, mixed layer; blue line = Globorotalia limbata (dextral), upper thermocline; red line = Neogloboquadrina dutertrei (dextral), lower thermocline; black line = Globorotalia tumida, bottom of the photic zone. B. Correction for species-specific offsets from $\delta^{13} C_{D I C}$.

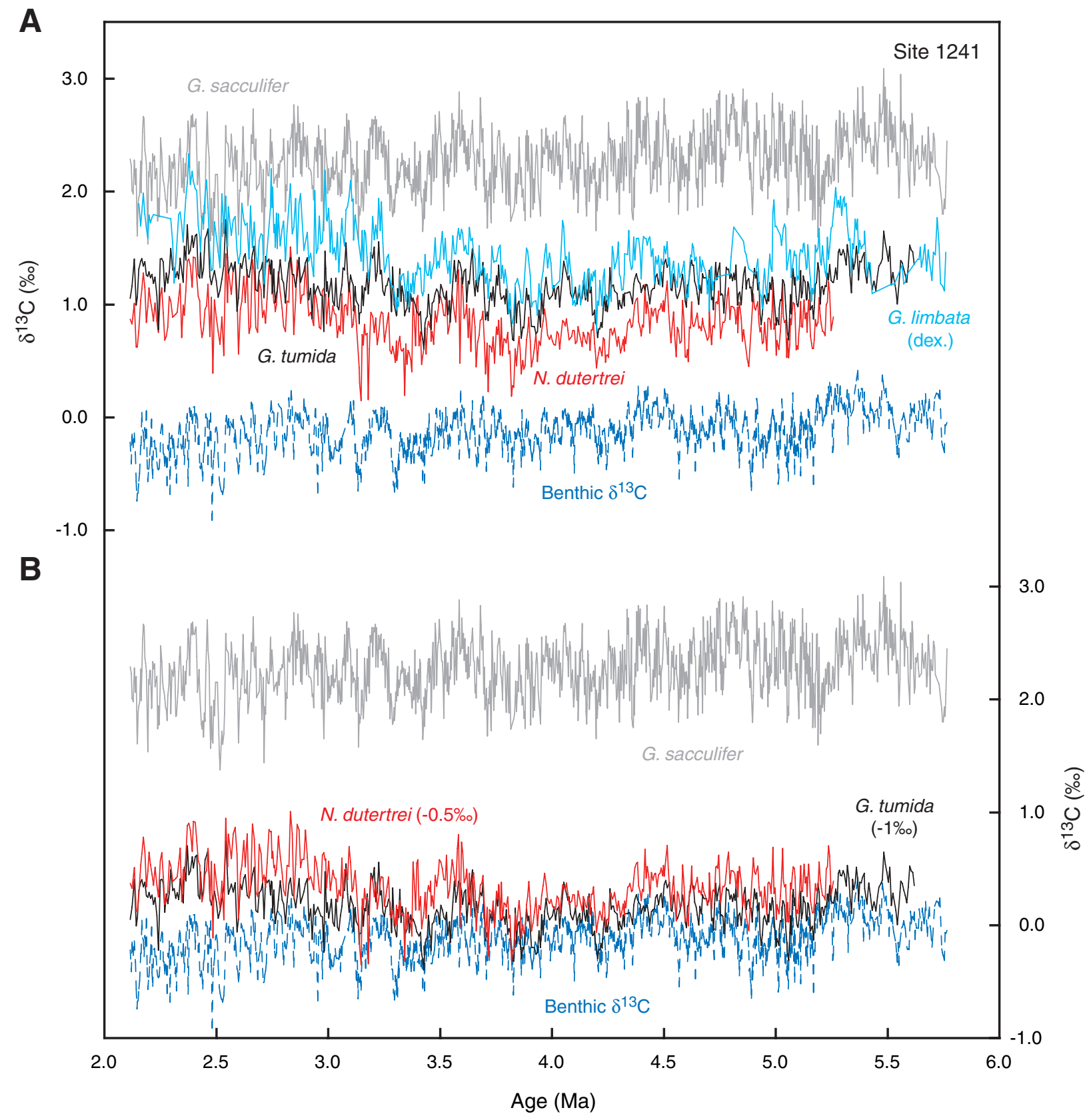


S. STEPH ET AL.

Tropical East Pacific UpPer OCEAN Stratification

Figure F11. $\delta^{13} \mathrm{C}$ record of the thermocline dweller Neogloboquadrina dutertrei (red line) from Site 1241 compared to the benthic $\delta^{13} \mathrm{C}$ record (black line) from Site 1236 (Nazca Ridge, 1323-m water depth, Tiedemann et al., this volume). The relatively shallow water depth of Site 1236 makes it suitable for monitoring changes in intermediate water composition.

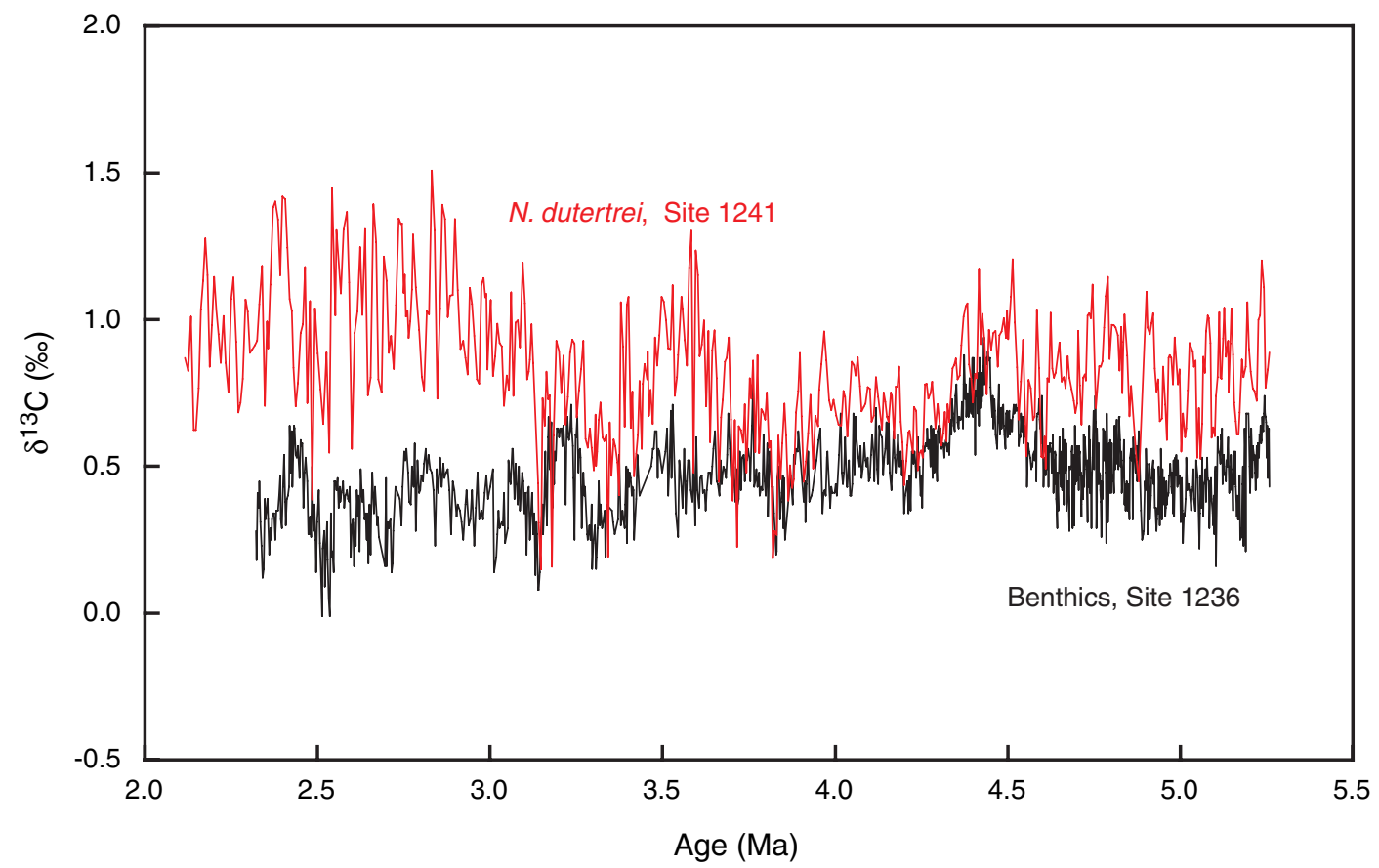


S. STEPH ET AL.

Tropical East Pacific UpPer OCEAN Stratification

Figure F12. Comparison between planktonic $\delta^{18} \mathrm{O}$ records from Sites 1241 (this study) and Site 851 (Cannariato and Ravelo, 1997). A. Globigerinoides sacculifer records. Black line $=$ Site 1241, red line $=$ Site 851 . B. Globorotalia tumida records. Black line $=$ Site 1241, red line $=$ Site 851.

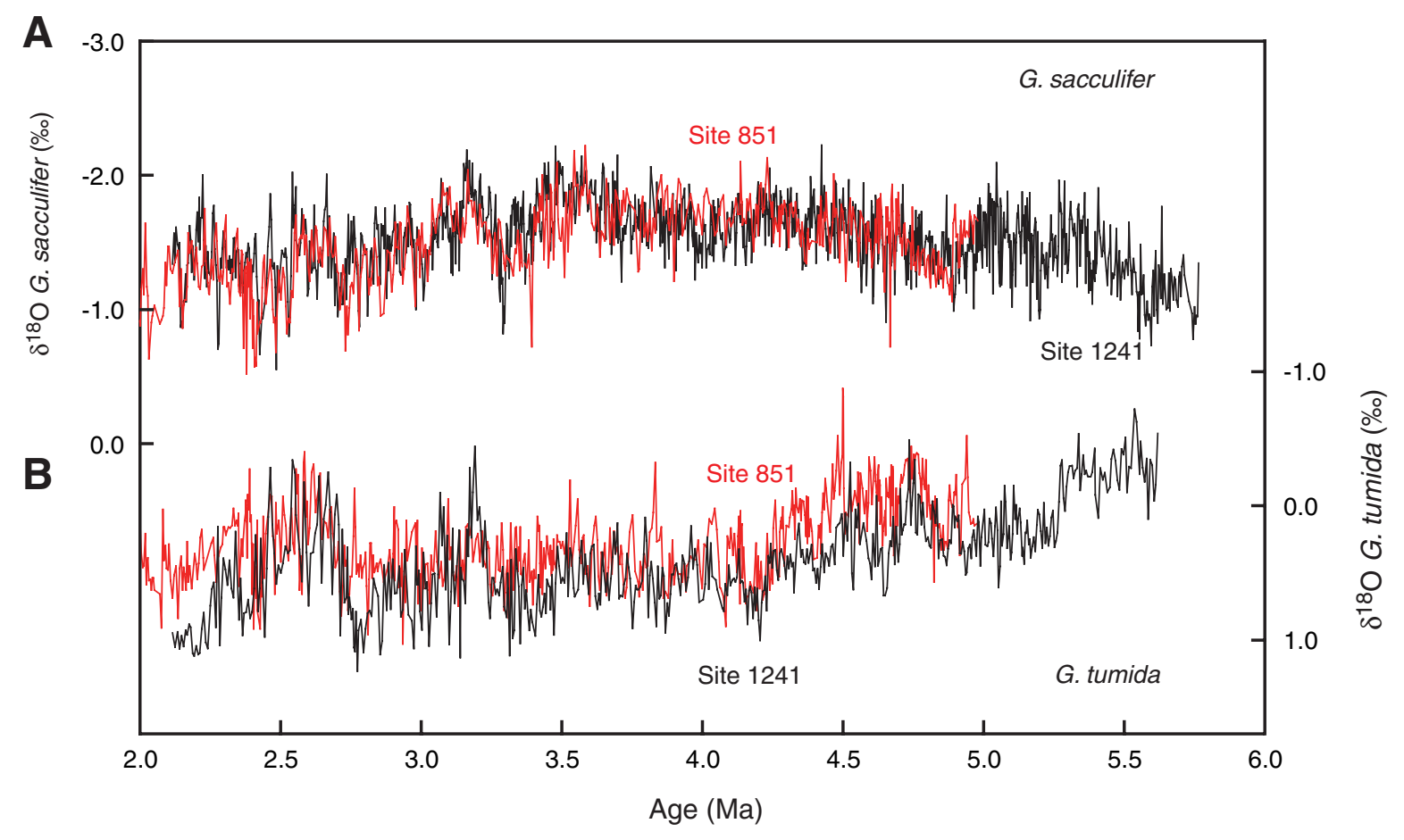


S. STEPH ET AL.

Tropical East Pacific UpPer OCEAN Stratification

Figure F13. Comparison between planktonic $\delta^{13} \mathrm{C}$ records from Sites 1241 (this study) and Site 851 (Cannariato and Ravelo, 1997). A. Globigerinoides sacculifer records. Black line $=$ Site 1241, red line $=$ Site 851 . B. Globorotalia tumida records. Black line $=$ Site 1241 , red line $=$ Site 851.

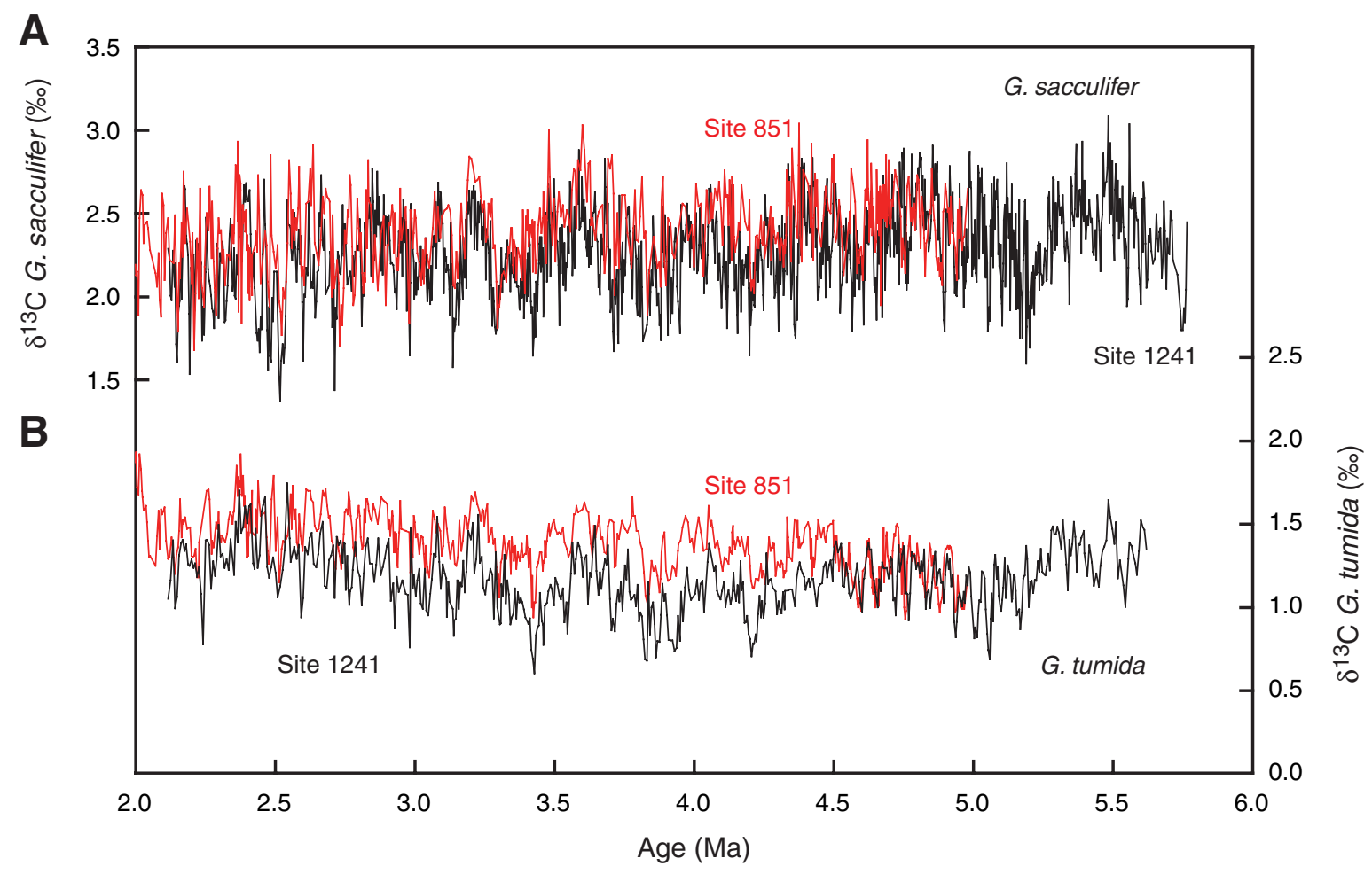


S. STEPH ET AL.

Tropical East Pacific UPPER OCEAN Stratification

Table T1. Isotope values of Globorotalia limbata (dextral) and Globoratalia menardii (dextral) from 14 selected samples and $\delta^{18} \mathrm{O}$ and $\delta^{13} \mathrm{C}$ offsets between the species.

\begin{tabular}{|c|c|c|c|c|c|c|c|}
\hline $\begin{array}{l}\text { Hole, core, section, } \\
\text { interval }(\mathrm{cm})\end{array}$ & $\begin{array}{l}\text { Age } \\
(\mathrm{Ma})\end{array}$ & $\begin{array}{l}\delta^{18} \mathrm{O} \\
\text { G. limbata } \\
\text { (dextral) } \\
(\% \mathrm{o})\end{array}$ & $\begin{array}{c}\delta^{18} \mathrm{O} \\
\text { G. menardii } \\
\text { (dextral) } \\
(\% \mathrm{o})\end{array}$ & $\begin{array}{c}\delta^{18} \mathrm{O} \text { difference } \\
(\% \text { o })\end{array}$ & $\begin{array}{c}\delta^{13} \mathrm{C} \\
\text { G. limbata } \\
\text { (dextral) } \\
(\% \text { o) }\end{array}$ & $\begin{array}{c}\delta^{13} \mathrm{C} \\
\text { G. menardii } \\
\text { (dextral) } \\
(\% \mathrm{o})\end{array}$ & $\begin{array}{c}\delta^{13} \mathrm{C} \text { difference } \\
(\% \text { o })\end{array}$ \\
\hline \multicolumn{8}{|l|}{ 202- } \\
\hline 1241C-3H-4, 0-2 & 2.443 & -0.447 & -0.599 & +0.152 & 1.775 & 1.507 & +0.268 \\
\hline 1241A-7H-4, 10-12 & 2.616 & -0.750 & -0.866 & +0.116 & 1.895 & 1.713 & +0.182 \\
\hline $1241 \mathrm{C}-4 \mathrm{H}-4,50-52$ & 2.866 & -0.837 & -0.932 & +0.095 & 1.805 & 1.830 & -0.025 \\
\hline $1241 \mathrm{~B}-8 \mathrm{H}-5,60-62$ & 3.118 & -1.051 & -1.259 & +0.208 & 1.530 & 1.569 & -0.039 \\
\hline $1241 \mathrm{C}-5 \mathrm{H}-6,60-62$ & 3.264 & -0.147 & -0.212 & +0.065 & 1.266 & 1.106 & +0.160 \\
\hline $1241 \mathrm{~A}-9 \mathrm{H}-4,130-132$ & 3.366 & 0.011 & -0.291 & +0.280 & 1.020 & 0.981 & +0.039 \\
\hline $1241 \mathrm{~A}-10 \mathrm{H}-3,80-82$ & 3.617 & -0.168 & -0.314 & +0.146 & 1.398 & 1.235 & +0.163 \\
\hline $1241 \mathrm{~A}-11 \mathrm{H}-5,30-32$ & 4.011 & -1.065 & -1.274 & +0.209 & 1.763 & 1.595 & +0.168 \\
\hline $1241 \mathrm{C}-8 \mathrm{H}-3,100-102$ & 4.110 & -0.545 & -0.658 & +0.113 & 1.367 & 1.269 & +0.098 \\
\hline $1241 \mathrm{~B}-12 \mathrm{H}-3,120-122$ & 4.367 & -0.670 & -0.712 & +0.042 & 1.474 & 1.272 & +0.202 \\
\hline 1241C-9H-3, 120-122 & 4.617 & -0.947 & -1.068 & +0.121 & 1.494 & 1.385 & +0.109 \\
\hline $1241 \mathrm{~A}-14 \mathrm{H}-5,90-92$ & 4.866 & -0.852 & -1.127 & +0.275 & 1.533 & 1.451 & +0.082 \\
\hline 1241A-15H-3, 10-12 & 5.017 & -0.989 & -1.267 & +0.278 & 1.659 & 1.562 & +0.097 \\
\hline $1241 \mathrm{~A}-16 \mathrm{H}-5,120-122$ & 5.366 & -0.867 & -0.901 & $\begin{array}{c}+0.034 \\
+0.152 \pm 0.085\end{array}$ & 1.546 & 1.473 & $\begin{array}{c}+0.073 \\
+0.112 \pm 0.086\end{array}$ \\
\hline
\end{tabular}


Table T2. Comparison of different Mg/Ca paleotemperature equations, Site 1241.

\begin{tabular}{|c|c|c|c|c|c|c|}
\hline Planktonic foraminifer & $\begin{array}{c}\mathrm{Mg} / \mathrm{Ca} \text { range/ } \\
\text { average } \mathrm{Mg} / \mathrm{Ca} \\
(\mathrm{mmol} / \mathrm{mol})\end{array}$ & $\mathrm{Mg} / \mathrm{Ca}$ temperature equation & $\begin{array}{l}\text { Temperature range/ } \\
\text { average temperature } \\
\left({ }^{\circ} \mathrm{C}\right)\end{array}$ & $\begin{array}{c}\text { Average } \\
\text { temperature } \\
\text { deviation* }\left({ }^{\circ} \mathrm{C}\right)\end{array}$ & $\begin{array}{c}\delta^{18} \mathrm{O}_{\text {seawater range }} / \\
\text { average } \delta^{18} \mathrm{O}_{\text {seawater }} \\
(\%))\end{array}$ & $\begin{array}{c}\text { Average } \\
\delta^{18} \mathrm{O}_{\text {seawater }} \\
\text { deviation* (\%o) }\end{array}$ \\
\hline \multirow[t]{5}{*}{ Globigerinoides sacculifer } & $2.503-4.045 / 3.233$ & Anand et al. (2003) & $20.95-26.28 / 23.76$ & & $-0.449-1.127 / 0.234$ & \\
\hline & & Nürnberg et al. (2000) & $21.43-27.75 / 24.77$ & +1.01 & $-0.273-1.385 / 0.448$ & +0.214 \\
\hline & & Dekens et al. (2002); Pacific & $23.97-29.30 / 26.79$ & +3.03 & $0.194-1.757 / 0.871$ & +0.637 \\
\hline & & Dekens et al. (2002); Atlantic & $21.97-27.30 / 24.79$ & +1.03 & $-0.229-1.343 / 0.452$ & +0.218 \\
\hline & & Elderfield and Ganssen (2000) & $15.71-20.51 / 18.25$ & -5.51 & $-1.647-0.095 /-0.974$ & -1.208 \\
\hline \multirow[t]{4}{*}{ Neogloboquadrina dutertrei } & $1.419-2.415 / 2.113$ & Anand et al. (2003) & $15.12-20.55 / 19.08$ & & $-0.557-1.159 / 0.103$ & \\
\hline & & Dekens et al. (2002); Pacific & $22.38-28.48 / 26.83$ & +7.75 & $1.100-2.829 / 1.772$ & +1.669 \\
\hline & & Dekens et al. (2002); Atlantic & $16.97-23.08 / 21.43$ & +2.35 & $-0.062-1.681 / 0.622$ & +0.519 \\
\hline & & Elderfield and Ganssen (2000) & $10.47-15.36 / 14.04$ & -5.04 & $-1.703-0.001 /-1.052$ & -1.155 \\
\hline \multirow[t]{2}{*}{ Globorotalia tumida } & $1.272-2.636 / 1.890$ & Anand et al. (2003) & $13.42-21.52 / 17.65$ & & $-0.328-1.309 / 0.741$ & \\
\hline & & Elderfield and Ganssen (2000) & $8.95-16.23 / 12.75$ & -4.90 & $-1.451-0.144 /-0.393$ & -1.134 \\
\hline \multirow[t]{2}{*}{ Globorotalia limbata } & $2.071-2.859 / 2.480$ & Anand et al. (2003) & $18.84-22.42 / 20.80$ & & $-0.337-0.981 / 0.408$ & \\
\hline & & Elderfield and Ganssen (2000) & $13.82-17.04 / 15.59$ & -5.91 & $-1.509-0.192 /-0.767$ & -1.175 \\
\hline
\end{tabular}

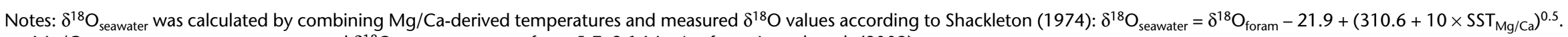
$\mathrm{Mg} / \mathrm{Ca}$ range, temperature range, and $\delta^{18} \mathrm{O}_{\text {seawater }}$ range are from 5.7-2.1 Ma. ${ }^{*}=$ from Anand et al. (2003). 
S. STEPH ET AL.

Tropical East Pacific Upper OCEAN Stratification

Table AT1. Oxygen and carbon isotopes of planktonic foraminifers, Site 1241.

\begin{tabular}{|c|c|c|c|c|c|c|c|c|c|c|}
\hline \multirow{2}{*}{$\begin{array}{l}\text { Core, section, } \\
\text { interval }(\mathrm{cm})\end{array}$} & \multirow{2}{*}{$\begin{array}{l}\text { Depth } \\
\text { (mcd) }\end{array}$} & \multirow{2}{*}{$\begin{array}{l}\text { Age } \\
(\mathrm{ka})\end{array}$} & \multicolumn{2}{|c|}{ G. sacculifer (\%o) } & \multicolumn{2}{|c|}{$\begin{array}{c}\text { N. dutertrei } \\
\text { (dextral) }(\% o)\end{array}$} & \multicolumn{2}{|c|}{ G. tumida (\%o) } & \multicolumn{2}{|c|}{$\begin{array}{c}\text { G. limbata } \\
\text { (dextral) (\%o) }\end{array}$} \\
\hline & & & $\delta^{13} \mathrm{C}$ & $\delta^{18} \mathrm{O}$ & $\delta^{13} \mathrm{C}$ & $\delta^{18} \mathrm{O}$ & $\delta^{13} \mathrm{C}$ & $\delta^{18} \mathrm{O}$ & $\delta^{13} \mathrm{C}$ & $\delta^{18} \mathrm{O}$ \\
\hline 202-1241A- & & & & & & & & & & \\
\hline $6 \mathrm{H}-1,110-112$ & 49.17 & 2116 & 2.29 & -1.34 & 0.87 & 0.08 & 1.05 & 0.95 & & \\
\hline $6 \mathrm{H}-1,122-124$ & 49.29 & 2121 & 2.23 & -1.57 & & & & & & \\
\hline $6 \mathrm{H}-1,130-132$ & 49.37 & 2125 & 2.01 & -1.35 & 0.83 & -0.31 & 1.16 & 1.05 & & \\
\hline $6 \mathrm{H}-1,140-142$ & 49.47 & 2130 & 1.98 & -1.61 & & & & & & \\
\hline $6 \mathrm{H}-2,0-2$ & 49.58 & 2135 & 2.28 & -1.48 & 1.01 & -0.25 & 1.40 & 0.94 & & \\
\hline $6 \mathrm{H}-2,10-12$ & 49.68 & 2139 & 2.06 & -1.44 & & & & & & \\
\hline $6 \mathrm{H}-2,20-22$ & 49.78 & 2142 & 2.20 & -1.50 & 0.62 & -0.23 & 0.99 & 1.07 & & \\
\hline $6 \mathrm{H}-2,30-32$ & 49.88 & 2146 & 1.71 & -0.87 & & & & & & \\
\hline $6 \mathrm{H}-2,38-40$ & 49.96 & 2148 & 1.61 & -0.91 & 0.62 & -0.13 & 1.06 & 0.97 & & \\
\hline $6 \mathrm{H}-2,50-52$ & 50.08 & 2152 & 1.89 & -0.86 & & & & & & \\
\hline $6 \mathrm{H}-2,60-62$ & 50.18 & 2155 & 1.95 & -1.06 & 0.77 & 0.11 & 1.31 & 1.05 & 1.89 & -0.12 \\
\hline $6 \mathrm{H}-2,70-72$ & 50.28 & 2159 & 1.97 & -1.04 & & & & & & \\
\hline $6 \mathrm{H}-2,82-84$ & 50.40 & 2162 & 2.27 & -1.26 & 1.03 & -0.09 & 1.38 & 0.93 & 1.70 & -0.41 \\
\hline $6 \mathrm{H}-2,90-92$ & 50.48 & 2165 & 1.99 & -1.06 & & & & & & \\
\hline $6 \mathrm{H}-2,100-102$ & 50.58 & 2168 & 2.25 & -1.33 & 1.13 & -0.14 & 1.40 & 0.97 & & \\
\hline $6 \mathrm{H}-2,110-112$ & 50.68 & 2172 & 2.53 & -1.35 & & & & & & \\
\hline $6 \mathrm{H}-2,122-124$ & 50.80 & 2175 & 2.66 & -1.54 & 1.28 & -0.32 & 1.34 & 0.88 & 1.98 & -0.80 \\
\hline $6 \mathrm{H}-2,130-132$ & 50.88 & 2178 & 2.65 & -1.62 & & & & & & \\
\hline $6 \mathrm{H}-2,140-142$ & 50.98 & 2181 & 2.37 & -1.52 & 1.15 & -0.05 & 1.38 & 0.91 & 1.80 & -0.64 \\
\hline $6 \mathrm{H}-3,0-2$ & 51.08 & 2185 & 2.32 & -1.28 & & & & & & \\
\hline $6 \mathrm{H}-3,10-12$ & 51.18 & 2188 & 2.25 & -1.47 & 0.84 & -0.11 & 1.26 & 1.10 & 1.68 & -0.57 \\
\hline $6 \mathrm{H}-3,20-22$ & 51.28 & 2191 & 1.90 & -1.36 & & & & & & \\
\hline $6 \mathrm{H}-3,30-32$ & 51.38 & 2194 & 1.54 & -1.22 & 0.98 & -0.17 & 1.25 & 1.12 & 1.58 & -0.22 \\
\hline $6 \mathrm{H}-3,42-44$ & 51.50 & 2198 & 2.17 & -1.44 & & & & & & \\
\hline $6 \mathrm{H}-3,50-52$ & 51.58 & 2201 & 2.13 & -1.59 & 1.15 & -0.45 & 1.29 & 1.05 & 1.79 & -0.37 \\
\hline $6 \mathrm{H}-3,60-62$ & 51.68 & 2204 & 2.26 & -1.72 & & & & & & \\
\hline $6 \mathrm{H}-3,70-72$ & 51.78 & 2207 & 2.25 & -1.51 & 1.03 & -0.26 & 1.24 & 1.11 & 1.72 & -0.42 \\
\hline $6 \mathrm{H}-3,82-84$ & 51.90 & 2211 & 1.92 & -1.83 & & & & & & \\
\hline $6 \mathrm{H}-3,90-92$ & 51.98 & 2214 & 2.01 & -1.45 & 0.95 & -0.39 & 1.27 & 1.10 & 1.77 & -0.55 \\
\hline $6 \mathrm{H}-3,100-102$ & 52.08 & 2217 & 2.34 & -1.68 & & & & & & \\
\hline $6 \mathrm{H}-3,110-112$ & 52.18 & 2221 & 2.27 & -1.68 & 0.85 & -0.16 & 1.18 & 0.92 & 1.79 & -0.64 \\
\hline $6 \mathrm{H}-3,122-124$ & 52.30 & 2225 & 2.31 & -2.00 & & & & & & \\
\hline $6 \mathrm{H}-3,130-132$ & 52.38 & 2228 & 2.11 & -1.52 & 1.01 & -0.47 & 1.24 & 0.80 & & \\
\hline $6 \mathrm{H}-3,140-142$ & 52.48 & 2231 & 2.17 & -1.23 & & & & & & \\
\hline $6 \mathrm{H}-4,0-2$ & 52.58 & 2235 & 2.20 & -1.47 & 0.85 & -0.51 & 1.08 & 1.02 & & \\
\hline $6 \mathrm{H}-4,10-12$ & 52.68 & 2239 & 1.74 & -1.17 & & & & & & \\
\hline $6 \mathrm{H}-4,20-22$ & 52.78 & 2242 & 1.94 & -1.43 & 0.75 & -0.22 & 0.78 & 1.07 & & \\
\hline $6 \mathrm{H}-4,30-32$ & 52.88 & 2246 & 1.77 & -1.27 & & & & & & \\
\hline $6 \mathrm{H}-4,42-44$ & 53.00 & 2250 & 2.15 & -1.26 & 1.07 & -0.06 & 1.40 & 0.75 & & \\
\hline $6 \mathrm{H}-4,50-52$ & 53.08 & 2253 & 2.47 & -1.23 & & & & & & \\
\hline $6 \mathrm{H}-4,60-62$ & 53.18 & 2256 & 2.33 & -1.43 & 1.14 & -0.18 & 1.41 & 0.62 & & \\
\hline $6 \mathrm{H}-4,70-72$ & 53.28 & 2260 & 2.16 & -1.72 & & & & & & \\
\hline $6 \mathrm{H}-4,82-84$ & 53.40 & 2264 & 2.10 & -1.77 & 0.93 & -0.25 & 1.37 & 0.57 & & \\
\hline $6 \mathrm{H}-4,90-92$ & 53.48 & 2267 & 2.07 & -1.45 & & & & & & \\
\hline $6 \mathrm{H}-4,100-102$ & 53.58 & 2270 & 2.01 & -1.33 & 0.68 & -0.27 & 1.11 & 0.91 & & \\
\hline $6 \mathrm{H}-4,110-112$ & 53.68 & 2274 & 1.93 & -1.22 & & & & & & \\
\hline $6 \mathrm{H}-4,122-124$ & 53.80 & 2278 & 1.91 & -0.70 & 0.72 & -0.23 & 1.28 & 0.16 & & \\
\hline $6 \mathrm{H}-4,130-132$ & 53.88 & 2281 & 1.81 & -0.74 & & & & & & \\
\hline $6 \mathrm{H}-4,140-142$ & 53.98 & 2284 & 2.03 & -1.21 & 0.80 & -0.02 & 1.19 & 1.04 & & \\
\hline $6 \mathrm{H}-5,2-4$ & 54.10 & 2288 & 2.13 & -1.38 & & & & & & \\
\hline $6 \mathrm{H}-5,10-12$ & 54.18 & 2291 & 2.32 & -1.31 & 1.07 & -0.36 & 1.29 & 0.69 & & \\
\hline $6 \mathrm{H}-5,20-22$ & 54.28 & 2295 & 2.29 & -1.45 & & & & & & \\
\hline $6 \mathrm{H}-5,30-32$ & 54.38 & 2298 & 1.87 & -1.58 & 1.03 & -0.35 & 1.49 & 0.39 & 1.76 & -0.53 \\
\hline $6 \mathrm{H}-5,42-44$ & 54.50 & 2302 & 2.26 & -1.51 & & & & & & \\
\hline $6 \mathrm{H}-5,50-52$ & 54.58 & 2305 & 2.24 & -1.47 & 0.89 & -0.43 & 1.31 & 0.48 & 1.55 & -0.72 \\
\hline $6 \mathrm{H}-5,60-62$ & 54.68 & 2309 & 2.21 & -1.31 & & & & & & \\
\hline $6 \mathrm{H}-5,70-72$ & 54.78 & 2312 & 2.33 & -1.36 & 0.90 & -0.26 & 1.32 & 0.59 & 1.19 & -0.66 \\
\hline $6 \mathrm{H}-5,82-84$ & 54.90 & 2316 & 2.24 & -1.30 & & & & & & \\
\hline $6 \mathrm{H}-5,90-92$ & 54.98 & 2319 & 1.85 & -1.40 & 0.91 & -0.20 & 1.24 & 0.41 & 1.36 & -0.44 \\
\hline $6 \mathrm{H}-5,100-102$ & 55.08 & 2322 & 1.86 & -1.27 & & & & & & \\
\hline $6 \mathrm{H}-5,110-112$ & 55.18 & 2326 & 1.97 & -1.37 & 0.93 & -0.36 & 1.29 & 0.62 & & \\
\hline $6 \mathrm{H}-5,122-124$ & 55.30 & 2330 & 2.07 & -1.22 & & & & & & \\
\hline $6 \mathrm{H}-5,130-132$ & 55.38 & 2333 & 2.24 & -1.53 & 1.05 & -0.31 & 1.23 & 0.69 & 1.79 & -0.75 \\
\hline
\end{tabular}

Note. Only a portion of this table appears here. The complete table is available in ASCII. 
S. STEPH ET AL.

Tropical East Pacific UpPer OCEAN Stratification

Table AT2. Mg/Ca ratios of deep-dwelling planktonic foraminifers, Site 1241. (Continued on next page.)

\begin{tabular}{|c|c|c|c|c|c|}
\hline \multirow[b]{2}{*}{$\begin{array}{l}\text { Core, section, } \\
\text { interval }(\mathrm{cm})\end{array}$} & \multirow[b]{2}{*}{$\begin{array}{l}\text { Depth } \\
\text { (mcd) }\end{array}$} & \multirow[b]{2}{*}{$\begin{array}{l}\text { Age } \\
\text { (ka) }\end{array}$} & \multicolumn{3}{|c|}{$\mathrm{Mg} / \mathrm{Ca}(\mathrm{mmol} / \mathrm{mol})$} \\
\hline & & & $\begin{array}{c}N . \\
\text { dutertrei } \\
\text { (dextral) }\end{array}$ & $\begin{array}{c}G . \\
\text { tumida }\end{array}$ & $\begin{array}{c}\text { G. } \\
\text { limbata } \\
\text { (dextral) }\end{array}$ \\
\hline \multicolumn{6}{|l|}{ 202-1241A- } \\
\hline $6 \mathrm{H}-1,110-112$ & 49.17 & 2116 & 2.08 & 1.46 & \\
\hline $6 \mathrm{H}-2,100-102$ & 50.58 & 2168 & 2.13 & 1.47 & \\
\hline $6 \mathrm{H}-3,110-112$ & 52.18 & 2221 & 1.88 & 1.53 & \\
\hline $6 \mathrm{H}-4,100-102$ & 53.58 & 2270 & 2.16 & 1.70 & \\
\hline $6 \mathrm{H}-5,110-112$ & 55.18 & 2326 & 2.00 & 1.60 & \\
\hline $7 \mathrm{H}-3,10-12$ & 61.55 & 2556 & & 1.87 & \\
\hline 7H-3, 20-22 & 61.65 & 2560 & & 1.85 & \\
\hline 7H-3, 30-32 & 61.75 & 2564 & & 1.93 & \\
\hline $7 \mathrm{H}-3,40-42$ & 61.85 & 2568 & & 1.78 & \\
\hline $7 \mathrm{H}-3,50-52$ & 61.95 & 2573 & & 1.59 & \\
\hline $7 \mathrm{H}-3,60-62$ & 62.05 & 2577 & 1.94 & 1.44 & \\
\hline $7 \mathrm{H}-4,30-32$ & 63.24 & 2623 & 1.99 & 1.75 & 2.39 \\
\hline $7 \mathrm{H}-4,40-42$ & 63.34 & 2627 & & 1.94 & 2.25 \\
\hline $7 \mathrm{H}-5,40-42$ & 64.85 & 2685 & 2.22 & 1.62 & \\
\hline $7 \mathrm{H}-5,50-52$ & 64.95 & 2689 & & 1.76 & \\
\hline 7H-5, 120-122 & 65.65 & 2714 & 2.00 & & 2.32 \\
\hline 7H-6, 10-12 & 66.06 & 2728 & 2.10 & 1.49 & 2.34 \\
\hline $9 \mathrm{H}-3,100-102$ & 84.05 & 3318 & 2.04 & 1.46 & \\
\hline $9 \mathrm{H}-4,110-112$ & 85.65 & 3361 & 2.21 & 1.52 & 2.10 \\
\hline $9 \mathrm{H}-5,90-92$ & 86.95 & 3396 & 2.18 & 1.50 & \\
\hline $9 \mathrm{H}-6,80-82$ & 88.36 & 3434 & 1.81 & 1.74 & \\
\hline $10 \mathrm{H}-2,60-62$ & 92.72 & 3565 & 2.13 & 1.42 & \\
\hline $10 \mathrm{H}-3,50-52$ & 94.12 & 3608 & 2.23 & 1.64 & 2.28 \\
\hline $10 \mathrm{H}-4,80-82$ & 95.92 & 3663 & 2.17 & 1.41 & \\
\hline $10 \mathrm{H}-5,70-72$ & 97.32 & 3704 & 2.09 & 1.56 & 2.40 \\
\hline $10 \mathrm{H}-6,20-22$ & 98.32 & 3733 & & 1.50 & \\
\hline $10 \mathrm{H}-6,60-62$ & 98.72 & 3744 & 2.10 & 1.44 & 2.37 \\
\hline $11 \mathrm{H}-4,40-42$ & 106.13 & 3961 & 2.20 & 1.59 & \\
\hline $11 \mathrm{H}-5,10-12$ & 107.34 & 4004 & 1.96 & 1.29 & \\
\hline $11 \mathrm{H}-5,110-112$ & 108.34 & 4036 & 1.96 & 1.41 & 2.25 \\
\hline $12 \mathrm{H}-3,20-22$ & 115.32 & 4225 & 2.35 & 1.70 & 2.47 \\
\hline $12 \mathrm{H}-4,10-12$ & 116.73 & 4260 & 2.01 & 1.88 & \\
\hline $12 \mathrm{H}-5,20-22$ & 118.34 & 4303 & 2.17 & 1.66 & 2.40 \\
\hline $13 \mathrm{H}-3,60-62$ & 125.61 & 4510 & 2.35 & 2.24 & 2.59 \\
\hline $13 \mathrm{H}-4,10-12$ & 126.62 & 4539 & 2.10 & 1.99 & \\
\hline $13 \mathrm{H}-5,20-22$ & 128.22 & 4585 & 2.22 & 2.11 & 2.60 \\
\hline $14 \mathrm{H}-1,50-52$ & 132.57 & 4703 & 2.07 & 2.10 & 2.69 \\
\hline $14 \mathrm{H}-2,10-12$ & 133.68 & 4728 & 2.12 & & \\
\hline $14 \mathrm{H}-2,20-22$ & 133.78 & 4730 & & 2.08 & \\
\hline $14 \mathrm{H}-3,20-22$ & 135.29 & 4765 & 2.20 & 2.25 & 2.44 \\
\hline $14 \mathrm{H}-4,0-2$ & 136.60 & 4799 & & 2.35 & \\
\hline $14 \mathrm{H}-4,10-12$ & 136.70 & 4802 & 2.24 & 2.25 & \\
\hline $14 \mathrm{H}-4,20-22$ & 136.80 & 4805 & & 2.20 & \\
\hline $14 \mathrm{H}-4,30-32$ & 136.90 & 4808 & & 2.29 & \\
\hline $14 \mathrm{H}-4,40-42$ & 137.00 & 4810 & & 2.08 & \\
\hline $14 \mathrm{H}-4,50-52$ & 137.10 & 4813 & & 2.25 & \\
\hline $14 \mathrm{H}-4,60-62$ & 137.20 & 4816 & & 2.35 & \\
\hline $14 \mathrm{H}-4,70-72$ & 137.30 & 4819 & & 2.33 & \\
\hline $14 \mathrm{H}-4,80-82$ & 137.40 & 4822 & & 2.39 & \\
\hline $14 \mathrm{H}-4,90-92$ & 137.50 & 4824 & & 2.58 & \\
\hline $14 \mathrm{H}-4,100-102$ & 137.60 & 4827 & & 2.26 & \\
\hline $14 \mathrm{H}-4,110-112$ & 137.70 & 4830 & & 2.38 & \\
\hline $14 \mathrm{H}-4,120-122$ & 137.80 & 4833 & 2.14 & 2.17 & \\
\hline $14 \mathrm{H}-4,130-132$ & 137.90 & 4835 & 2.19 & 2.37 & \\
\hline $14 \mathrm{H}-4,140-142$ & 138.00 & 4838 & & 2.14 & \\
\hline $14 \mathrm{H}-5,0-2$ & 138.11 & 4841 & & 2.10 & \\
\hline $14 \mathrm{H}-5,10-12$ & 138.21 & 4844 & & 2.38 & \\
\hline $14 \mathrm{H}-5,20-22$ & 138.31 & 4847 & 2.21 & 2.14 & 2.67 \\
\hline $14 \mathrm{H}-5,30-32$ & 138.41 & 4850 & & 2.32 & \\
\hline $14 \mathrm{H}-5,40-42$ & 138.51 & 4852 & 2.12 & 2.31 & \\
\hline $14 \mathrm{H}-5,50-52$ & 138.61 & 4855 & & 2.32 & \\
\hline $14 \mathrm{H}-5,60-62$ & 138.71 & 4858 & & 2.23 & \\
\hline $14 \mathrm{H}-5,70-72$ & 138.81 & 4861 & & 2.13 & \\
\hline $14 \mathrm{H}-5,80-82$ & 138.91 & 4863 & & 2.26 & \\
\hline $14 \mathrm{H}-5,90-92$ & 139.01 & 4866 & & 2.12 & \\
\hline $14 \mathrm{H}-5,100-102$ & 139.11 & 4869 & & 1.94 & \\
\hline
\end{tabular}

\begin{tabular}{|c|c|c|c|c|c|}
\hline \multirow[b]{2}{*}{$\begin{array}{l}\text { Core, section, } \\
\text { interval }(\mathrm{cm})\end{array}$} & \multirow[b]{2}{*}{$\begin{array}{l}\text { Depth } \\
\text { (mcd) }\end{array}$} & \multirow[b]{2}{*}{$\begin{array}{l}\text { Age } \\
(\mathrm{ka})\end{array}$} & \multicolumn{3}{|c|}{$\mathrm{Mg} / \mathrm{Ca}(\mathrm{mmol} / \mathrm{mol})$} \\
\hline & & & $\begin{array}{c}N . \\
\text { dutertrei } \\
\text { (dextral) }\end{array}$ & $\begin{array}{c}\text { G. } \\
\text { tumida }\end{array}$ & $\begin{array}{c}\text { G. } \\
\text { limbata } \\
\text { (dextral) }\end{array}$ \\
\hline $14 \mathrm{H}-5,110-112$ & 139.21 & 4872 & & 2.26 & \\
\hline $14 \mathrm{H}-5,120-122$ & 139.31 & 4875 & 2.14 & 2.08 & \\
\hline $14 \mathrm{H}-5,130-132$ & 139.41 & 4877 & & 2.15 & \\
\hline $14 \mathrm{H}-5,140-142$ & 139.51 & 4880 & 1.48 & 2.09 & \\
\hline $14 \mathrm{H}-6,0-2$ & 139.62 & 4883 & & 2.27 & \\
\hline $14 \mathrm{H}-6,10-12$ & 139.72 & 4885 & & 2.11 & \\
\hline $14 \mathrm{H}-6,20-22$ & 139.82 & 4888 & & 2.48 & \\
\hline $14 \mathrm{H}-6,30-32$ & 139.92 & 4890 & & 2.20 & \\
\hline $14 \mathrm{H}-6,40-42$ & 140.02 & 4893 & & 2.12 & \\
\hline $15 \mathrm{H}-3,10-12$ & 145.24 & 5017 & 2.18 & 2.16 & \\
\hline $15 \mathrm{H}-4,20-22$ & 146.85 & 5055 & 2.22 & 1.95 & 2.83 \\
\hline $15 \mathrm{H}-5,10-12$ & 148.26 & 5084 & 2.23 & 1.87 & \\
\hline $15 \mathrm{H}-6,20-22$ & 149.87 & 5116 & 2.25 & 2.05 & 2.66 \\
\hline $16 \mathrm{H}-5,120-122$ & 160.40 & 5366 & & 2.64 & 2.86 \\
\hline $17 \mathrm{H}-4,90-92$ & 168.66 & 5566 & & 2.45 & \\
\hline $17 \mathrm{H}-6,30-32$ & 171.07 & 5620 & & 2.38 & \\
\hline \multicolumn{6}{|l|}{ 202-1241B- } \\
\hline $8 \mathrm{H}-3,20-22$ & 73.87 & 3009 & 2.11 & 1.60 & 2.57 \\
\hline $8 \mathrm{H}-4,10-12$ & 75.27 & 3055 & 2.00 & 1.27 & \\
\hline $8 \mathrm{H}-5,20-22$ & 76.87 & 3107 & 2.34 & 1.54 & 2.62 \\
\hline $12 \mathrm{H}-3,20-22$ & 119.71 & 4340 & & 1.73 & \\
\hline $12 \mathrm{H}-3,30-32$ & 119.81 & 4342 & 2.16 & & \\
\hline $12 \mathrm{H}-4,10-12$ & 121.12 & 4378 & 2.17 & 1.90 & 2.25 \\
\hline $12 \mathrm{H}-5,20-22$ & 122.73 & 4422 & 2.42 & 1.63 & 2.34 \\
\hline $12 \mathrm{H}-6,10-12$ & 124.13 & 4465 & 2.25 & 2.01 & \\
\hline $14 \mathrm{H}-2,110-112$ & 140.38 & 4902 & 2.24 & & \\
\hline $14 \mathrm{H}-3,20-22$ & 140.99 & 4917 & 2.22 & 2.08 & 2.74 \\
\hline $14 \mathrm{H}-3,120-122$ & 141.99 & 4941 & 2.26 & & \\
\hline $14 \mathrm{H}-4,10-12$ & 142.40 & 4952 & 2.11 & 1.99 & \\
\hline $14 \mathrm{H}-5,20-22$ & 144.01 & 4989 & 2.13 & 2.00 & 2.63 \\
\hline $16 \mathrm{H}-2,60-62$ & 161.96 & 5408 & & 2.48 & \\
\hline $16 \mathrm{H}-3,60-62$ & 163.47 & 5449 & & 2.35 & 2.68 \\
\hline $16 \mathrm{H}-4,60-62$ & 164.98 & 5484 & & 2.41 & \\
\hline $16 \mathrm{H}-6,0-2$ & 167.37 & 5538 & & 2.49 & \\
\hline \multicolumn{6}{|l|}{ 202-1241C- } \\
\hline $3 \mathrm{H}-2,90-92$ & 56.10 & 2358 & 2.25 & 1.42 & \\
\hline $3 \mathrm{H}-3,30-32$ & 57.00 & 2389 & 2.35 & & \\
\hline $3 \mathrm{H}-3,82-84$ & 57.52 & 2407 & & 1.70 & \\
\hline $3 \mathrm{H}-4,0-2$ & 58.21 & 2443 & & 1.71 & \\
\hline $3 \mathrm{H}-4,10-12$ & 58.31 & 2446 & & 1.53 & 2.10 \\
\hline $3 \mathrm{H}-4,20-22$ & 58.41 & 2448 & 1.90 & 1.67 & 2.07 \\
\hline $3 \mathrm{H}-4,30-32$ & 58.51 & 2451 & & 1.37 & \\
\hline $3 \mathrm{H}-4,40-42$ & 58.61 & 2454 & & 1.54 & \\
\hline $3 \mathrm{H}-4,50-52$ & 58.71 & 2456 & & 1.49 & \\
\hline $3 \mathrm{H}-4,60-62$ & 58.81 & 2459 & & 1.50 & \\
\hline $3 \mathrm{H}-4,70-72$ & 58.91 & 2462 & & 1.68 & \\
\hline $3 \mathrm{H}-4,80-82$ & 59.01 & 2465 & & 1.76 & \\
\hline $3 \mathrm{H}-4,90-92$ & 59.11 & 2467 & & 1.97 & \\
\hline $3 \mathrm{H}-4,100-102$ & 59.21 & 2470 & & 1.93 & \\
\hline $3 \mathrm{H}-4,110-112$ & 59.31 & 2473 & & 2.20 & \\
\hline $3 \mathrm{H}-4,120-122$ & 59.41 & 2475 & & 2.05 & \\
\hline $3 \mathrm{H}-4,130-132$ & 59.51 & 2478 & & 1.98 & \\
\hline $3 \mathrm{H}-4,140-142$ & 59.61 & 2481 & & 1.88 & \\
\hline $3 \mathrm{H}-5,0-2$ & 59.72 & 2484 & & 1.87 & \\
\hline $3 \mathrm{H}-5,10-12$ & 59.82 & 2486 & & 1.59 & \\
\hline $3 \mathrm{H}-5,20-22$ & 59.92 & 2489 & & 1.87 & \\
\hline $3 \mathrm{H}-5,30-32$ & 60.02 & 2493 & 2.20 & 1.97 & \\
\hline $3 \mathrm{H}-5,40-42$ & 60.12 & 2497 & & 1.75 & \\
\hline $3 \mathrm{H}-5,50-52$ & 60.22 & 2501 & & 2.08 & \\
\hline $3 \mathrm{H}-5,60-62$ & 60.32 & 2506 & & 1.69 & \\
\hline $3 \mathrm{H}-5,70-72$ & 60.42 & 2510 & & 1.82 & \\
\hline $3 \mathrm{H}-5,80-82$ & 60.52 & 2514 & & 1.82 & \\
\hline $3 \mathrm{H}-5,90-92$ & 60.62 & 2518 & & 1.89 & \\
\hline $3 \mathrm{H}-5,100-102$ & 60.72 & 2522 & & 1.73 & \\
\hline $3 \mathrm{H}-5,110-112$ & 60.82 & 2526 & & 1.98 & \\
\hline $3 \mathrm{H}-5,120-122$ & 60.92 & 2530 & & 1.96 & \\
\hline
\end{tabular}


S. STEPH ET AL.

Tropical East Pacific Upper OCEAN STRATIfication

Table AT2 (continued).

\begin{tabular}{|c|c|c|c|c|c|}
\hline \multirow[b]{2}{*}{$\begin{array}{l}\text { Core, section, } \\
\text { interval }(\mathrm{cm})\end{array}$} & \multirow[b]{2}{*}{$\begin{array}{l}\text { Depth } \\
\text { (mcd) }\end{array}$} & \multirow[b]{2}{*}{$\begin{array}{l}\text { Age } \\
(\mathrm{ka})\end{array}$} & \multicolumn{3}{|c|}{$\mathrm{Mg} / \mathrm{Ca}(\mathrm{mmol} / \mathrm{mol})$} \\
\hline & & & $\begin{array}{c}N . \\
\text { dutertrei } \\
\text { (dextral) }\end{array}$ & $\begin{array}{c}G . \\
\text { tumida }\end{array}$ & $\begin{array}{c}\text { G. } \\
\text { limbata } \\
\text { (dextral) }\end{array}$ \\
\hline $3 \mathrm{H}-5,130-132$ & 61.02 & 2534 & 1.86 & 1.61 & \\
\hline $3 \mathrm{H}-5,140-142$ & 61.12 & 2538 & & 1.89 & \\
\hline $3 \mathrm{H}-6,0-2$ & 61.23 & 2543 & & 1.83 & \\
\hline $3 \mathrm{H}-6,10-12$ & 61.33 & 2547 & & 1.67 & 2.36 \\
\hline $3 \mathrm{H}-6,20-22$ & 61.43 & 2551 & & 2.18 & \\
\hline $3 \mathrm{H}-6,30-32$ & 61.53 & 2555 & & 1.95 & \\
\hline $4 \mathrm{H}-2,40-42$ & 66.56 & 2746 & 2.06 & & 2.44 \\
\hline $4 \mathrm{H}-2,140-142$ & 67.56 & 2786 & 2.04 & 1.53 & \\
\hline $4 \mathrm{H}-3,110-112$ & 68.77 & 2832 & 1.92 & 1.51 & 2.34 \\
\hline $4 \mathrm{H}-4,40-42$ & 69.59 & 2863 & 2.09 & 1.48 & \\
\hline $4 \mathrm{H}-5,70-72$ & 71.40 & 2929 & 1.96 & 1.55 & 2.53 \\
\hline $4 \mathrm{H}-6,80-82$ & 73.01 & 2981 & 2.18 & & \\
\hline $5 \mathrm{H}-3,10-12$ & 78.16 & 3142 & 2.08 & 1.47 & \\
\hline $5 \mathrm{H}-4,40-42$ & 79.96 & 3192 & 2.14 & 1.63 & 2.48 \\
\hline $5 \mathrm{H}-5,50-52$ & 81.56 & 3246 & 2.20 & 1.38 & \\
\hline $5 \mathrm{H}-6,20-22$ & 82.77 & 3284 & 1.92 & 1.67 & 2.43 \\
\hline $6 \mathrm{H}-3,60-62$ & 89.63 & 3466 & 2.04 & 1.51 & \\
\hline $6 \mathrm{H}-4,50-52$ & 91.03 & 3511 & 1.98 & 1.44 & 2.25 \\
\hline 7H-3, 10-12 & 99.42 & 3764 & 2.06 & 1.54 & \\
\hline $7 \mathrm{H}-4,20-22$ & 101.02 & 3808 & 2.09 & 1.37 & 2.51 \\
\hline 7H-5, 10-12 & 102.42 & 3848 & 2.10 & 1.57 & 2.16 \\
\hline 7H-5, 70-72 & 103.02 & 3864 & 2.00 & & 2.58 \\
\hline 7H-5, 110-112 & 103.42 & 3876 & 2.08 & & 2.51 \\
\hline 7H-5, 130-132 & 103.62 & 3881 & 2.16 & & 2.64 \\
\hline 7H-6, 20-22 & 104.02 & 3892 & 2.14 & 1.49 & \\
\hline 7H-7, 10-12 & 105.42 & 3937 & 2.15 & 1.57 & 2.54 \\
\hline $8 \mathrm{H}-2,40-42$ & 108.76 & 4048 & 2.12 & 1.54 & \\
\hline $8 \mathrm{H}-3,30-32$ & 110.16 & 4089 & 2.06 & 1.61 & 2.37 \\
\hline $8 \mathrm{H}-4,40-42$ & 111.76 & 4136 & 2.29 & 1.50 & \\
\hline $8 \mathrm{H}-5,30-32$ & 113.16 & 4171 & 2.19 & 1.57 & 2.55 \\
\hline $8 \mathrm{H}-6,40-42$ & 114.76 & 4211 & 2.27 & 1.64 & \\
\hline $9 \mathrm{H}-3,110-112$ & 129.34 & 4615 & 1.91 & 2.06 & \\
\hline $9 \mathrm{H}-4,20-22$ & 129.94 & 4629 & 2.25 & 2.01 & 2.61 \\
\hline $9 \mathrm{H}-5,10-12$ & 131.35 & 4669 & 2.16 & 2.23 & \\
\hline $11 \mathrm{H}-2,90-92$ & 150.97 & 5139 & 2.23 & 1.99 & \\
\hline $11 \mathrm{H}-3,10-12$ & 151.67 & 5153 & 2.28 & 2.12 & 2.83 \\
\hline $11 \mathrm{H}-4,20-22$ & 153.27 & 5189 & 2.34 & 2.14 & \\
\hline $11 \mathrm{H}-5,10-12$ & 154.67 & 5227 & 2.05 & 2.24 & 2.71 \\
\hline $11 \mathrm{H}-6,40-42$ & 156.48 & 5275 & & 2.52 & 2.83 \\
\hline 11H-7, 10-12 & 157.68 & 5307 & & 2.44 & \\
\hline
\end{tabular}

